\title{
WestVirginiaUniversity
}

THE RESEARCH REPOSITORY @ WVU

Graduate Theses, Dissertations, and Problem Reports

2018

\section{Predictive Content of Portfolio Flows for the Real Economy}

\author{
Golnaz Baradaran Motie
}

Follow this and additional works at: https://researchrepository.wvu.edu/etd

\section{Recommended Citation}

Motie, Golnaz Baradaran, "Predictive Content of Portfolio Flows for the Real Economy" (2018). Graduate Theses, Dissertations, and Problem Reports. 7160.

https://researchrepository.wvu.edu/etd/7160

This Dissertation is protected by copyright and/or related rights. It has been brought to you by the The Research Repository @ WVU with permission from the rights-holder(s). You are free to use this Dissertation in any way that is permitted by the copyright and related rights legislation that applies to your use. For other uses you must obtain permission from the rights-holder(s) directly, unless additional rights are indicated by a Creative Commons license in the record and/ or on the work itself. This Dissertation has been accepted for inclusion in WVU Graduate Theses, Dissertations, and Problem Reports collection by an authorized administrator of The Research Repository @ WVU.

For more information, please contact researchrepository@mail.wvu.edu. 


\title{
Predictive Content of Portfolio Flows for the Real Economy
}

\author{
Golnaz Baradaran Motie \\ Dissertation submitted \\ to the College of Business and Economics at West Virginia University \\ in partial fulfillment of the requirements for the degree of \\ Doctor of Philosophy in Department of Economics
}

Arabinda Basistha, Ph.D., Chair
Stratford Douglas, Ph.D.
Eric Olson, Ph.D.
Jack Dorminey, Ph.D.
Department of Economics
Morgantown, West Virginia 2018

Keywords: capital inflows, portfolio inflows, equity inflows, debt inflows, US GDP, UK GDP, forecasting, three-pass regression filter

Copyright 2018 Golnaz Baradaran Motie 


\section{ABSTRACT \\ Predictive Content of Portfolio Flows for the Real Economy}

\section{Golnaz Baradaran Motie}

The aim of this dissertation is to study predictive content of foreign portfolio investment and its components for the real economy of the US and the UK. Despite the large volume of foreign portfolio investment, there are limited studies of how advanced economies are affected by portfolio inflow. Empirical studies show that the effect of portfolio inflows on growth in emerging economies is low, possibly due to underdeveloped financial infrastructure. The first chapter estimates show a positive and significant long-run effect of 0.7 percentage points on US real GDP following a one standard deviation shock to foreign portfolio investment. Further estimates reveal that positive shocks to portfolio equity and debt inflows also affect the US economy positively in the long-run.

The second chapter forecasts US GDP using capital flow variables. Capital flow series have been mainly overlooked in the forecasting of US real GDP. The study applies the three-pass regression filter (3PRF) method to forecast US real GDP by using capital flow as well as trade series. It uses mean square forecast error (MSFE) metric to evaluate the performance of 3PRF forecasts in comparison to autoregressive (AR) and autoregressive distributed lag (ARDL) models. The results show that out-of-sample 3PRF forecasts perform better than AR forecasts by at least 13 percent in shorter horizons. In-sample and out-of-sample 3PRF forecasts that use capital flow and trade variables perform better than benchmark models in all forecasting horizons.

The third chapter studies the effects of foreign portfolio investment and its components, equity and debt, on the UK Economy. Foreign portfolio investment in the UK has increased over the years and it currently accounts for 37 percent of total foreign investment in the UK, over \$10 trillion at the end of 2016. Limited studies on advanced economies and the results of the first chapter that show portfolio investment and its components have positive effects on US real GDP in the longrun are the motivations for this chapter. This chapter investigates whether the positive effects of portfolio investment are unique to the US by studying the UK. The structural VAR estimates show that one standard deviation shock to portfolio investment has a positive effect of UK GDP. Equity inflow, similar to the US case, has a positive and significant effect on the UK economy. A debt inflow shock shows a negative effect on the UK GDP and investment in the post-financial crisis period while it shows no impact in the pre-financial crisis. 


\section{Dedication}

This dissertation is dedicated to my parents in Iran. Thank you for your unconditional love and support. 


\section{Acknowledgement}

I would like to thank my advisor Dr. Arabinda Basistha for his guidance and support throughout the $\mathrm{PhD}$ program. None of this would have been possible without his help. I would also like to thank the other member of my dissertation committee, Dr. Stratford Douglas, Dr. Eric Olson and Dr. Jack Dorminey, and my friend, Patrick Reilly, for reading my dissertation and providing me with helpful comments and feedback. 


\section{Table of Contents}

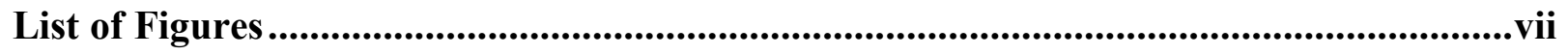

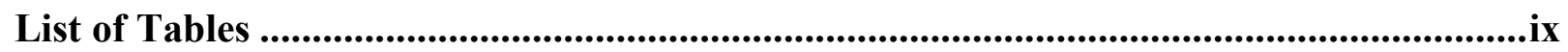

Chapter 1: Foreign Portfolio Investment and US Output..............................................1

1.1. Introduction ........................................................................................

1.2. Empirical Background on International Capital Flows...................................... 3

1.3. Structural VAR Models ...................................................................... 10

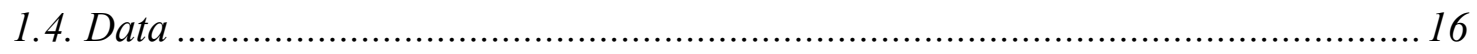

1.5. Primary Empirical Results ................................................................. 19

1.6. Results from Local Projection Method .................................................... 22

1.7. Results from Factor Augmented VAR Models................................................25

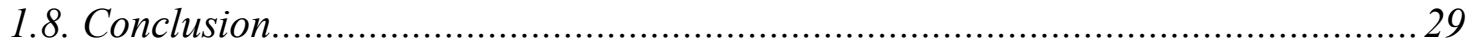

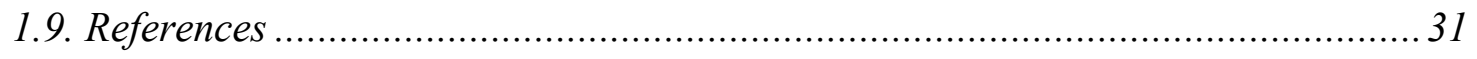

Chapter 2: Forecasting US GDP Growth, Does Foreign Investment Matter?...................54

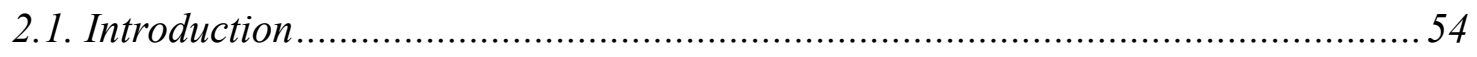

2.2. Empirical Background on Capital Flow and Growth ...................................56

2.3. Forecasting Methods ................................................................... 57

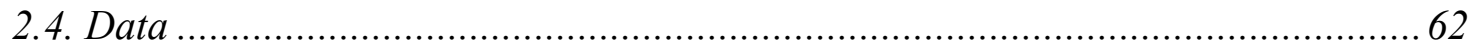

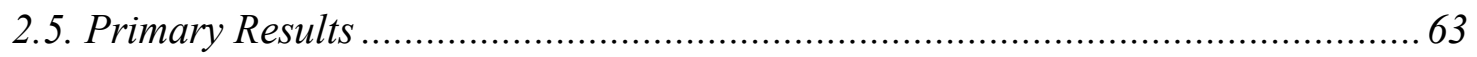


2.7. Conclusion. 65

2.8. References 67

Chapter 3: Foreign Portfolio Investment and the Real Economy in the United Kingdom 76

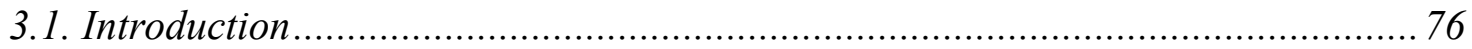

3.2. Empirical Background on International Capital Flows .................................. 78

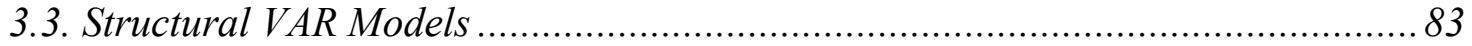

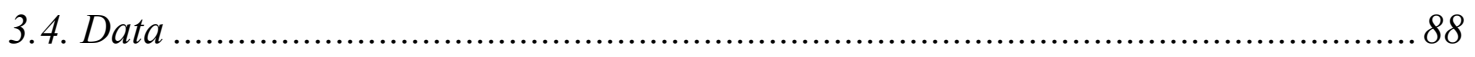

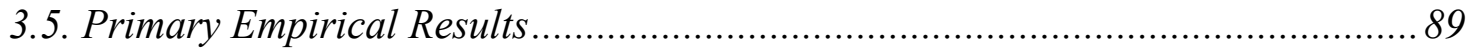

3.6. Results from Factor Augmented VAR Models .................................................. 91

3.7. Effect of Equity and Debt Inflows on GDP Components ............................... 93

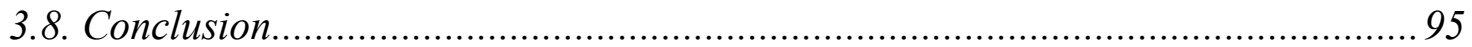

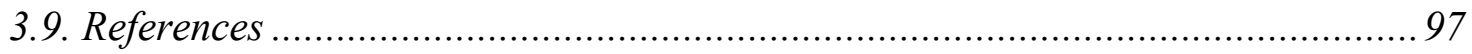




\section{List of Figures}

Figure 1-1-US international investments 37

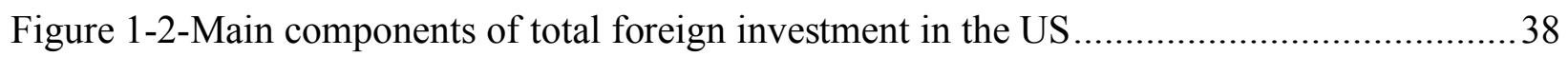

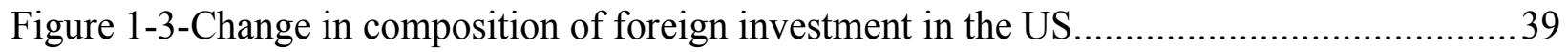

Figure 1-4-Debt and equity as share of portfolio investment............................................ 40

Figure 1-5-Impulse responses for US GDP and net foreign investments ..........................41

Figure 1-6-Impulse responses for US GDP, capital inflow and capital outflow......................42

Figure 1-7-Impulse responses for US GDP, FDI, portfolio inflow and bank credits.................43

Figure 1-8-FDI current cost and market value ..................................................... 44

Figure 1-9-Impulse responses for US GDP, FDI, portfolio inflow and bank credits.................45

Figure 1-10-Impulse responses for US GDP, equity and debt inflow ..................................46

Figure 1-11-Impulse responses for US GDP, government debt and corporate debt .................47

Figure 1-12-LP impulse responses for US GDP and portfolio inflow ............................... 48

Figure 1-13-LP impulse responses for US GDP, equity and debt inflow...............................49

Figure 1-14-LP impulse responses for US GDP, government and corporate debt....................50

Figure 1-15-FAVAR impulse responses for US GDP and portfolio inflow ...........................51

Figure 1-16-FAVAR impulse responses for US GDP, equity inflow and debt inflow ...............52

Figure 1-17-FAVAR impulse responses for US GDP, government and corporate debt............53

Figure 3-1-Components of foreign investments in the UK........................................ 101

Figure 3-2-Debt and equity as share of portfolio investment........................................ 102

Figure 3-3-Impulse responses for net foreign investment and UK GDP ........................... 103

Figure 3-4-Impulse responses for FDI, portfolio inflow, bank credit and UK GDP................ 105

Figure 3-5-Impulse responses for equity inflow, debt inflow and UK GDP ......................... 107 
Figure 3-6-FAVAR impulse responses for equity inflow, debt inflow and UK GDP ............. 110

Figure 3-7-Impulse responses for equity inflow and debt inflow and UK investment.............. 111

Figure 3-8-Impulse responses for equity inflow and debt inflow and UK consumption............ 114 


\section{List of Tables}

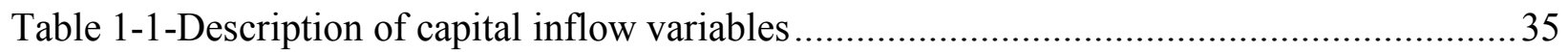

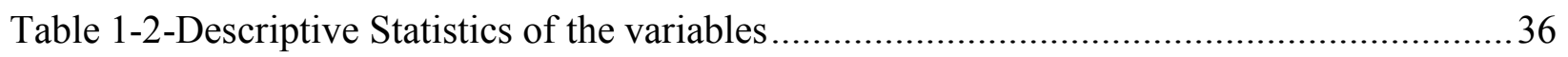

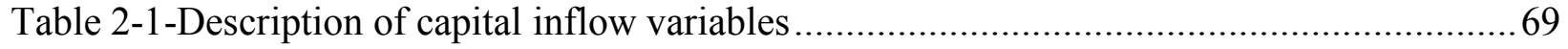

Table 2-2- Description of capital outflow variables ..................................................... 70

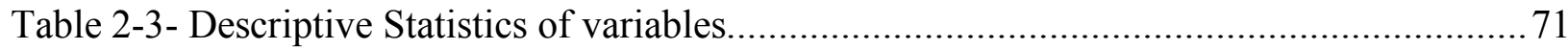

Table 2-4- In-sample 3PRF forecasts of US GDP growth ......................................... 72

Table 2-5- Out-of-sample 3PRF forecasts of US GDP growth...................................... 73

Table 2-6- Comparison of in-sample forecasts of 3PRF and principal components................. 74

Table 2-7- Comparison of out-of-sample forecasts of 3PRF and principal components ............75

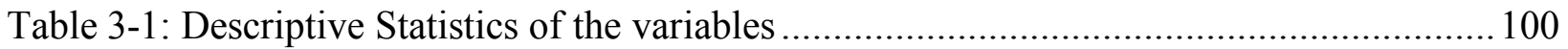




\section{Chapter 1: Foreign Portfolio Investment and US}

\section{Output}

\subsection{Introduction}

Foreign investment in the US is at an all-time high. At the end of the first quarter of 2017 it reached over $\$ 24$ trillion, more than 70 percent of which was portfolio investment. The effect of international capital inflow on emerging economies has been extensively studied highlighting important aspects of international capital inflow and their impacts on those economies. ${ }^{1}$ Although multiple studies include advanced economies in their panels for comparison purposes, very few papers focus on the impact of foreign capital flows on advanced economies in general and on the US in particular ${ }^{2,3}$. This chapter contributes to the literature by studying how foreign portfolio investment in the US has changed over time and how it affects US real GDP.

We use structural VAR models to estimate the dynamic effect of capital inflow on US GDP. There are two advantages to this approach. First, it allows for feedback effects between the variables of interest. Second, it allows us to study the short-term and long-term effects of shocks to capital inflow variables on US GDP. We also compare our main results with local projection

\footnotetext{
${ }^{1}$ See Bosworth and Collins (1999) for the saving and investment implications of capital flows, Prasad et al. (2007) for the relationship between financial market development and the beneficial effect of foreign capital on growth and Blanchard et al. (2016) for how debt versus non-debt portions of capital inflow can affect growth differently. They found that increases in debt and non-debt capital inflows have contractionary and expansionary effects, respectively.

${ }^{2}$ Durham (2003) shows statistically insignificant effect of portfolio inflow and negative effect of bank lending on growth. Aizenman et al. (2013) show the positive effect of FDI and equity investments and the insignificant impact of short term debt on economic growth.

${ }^{3}$ Warnock and Warnock (2009) analyze the impact of international capital inflow on US long-term interest rates. They showed that US long-term interest rates would have been 80 basis points higher in the absence of international capital inflow for one year.
} 
impulse responses that are known to be robust to lag misspecifications. Finally, we use factor augmented VAR (FAVAR) to investigate whether the inclusion of US monetary policy affects our main results.

Our standard structural VAR impulse responses show that positive shocks to portfolio inflow and its components have positive impacts on US GDP in the long-run. We find that a one standard deviation shock to portfolio inflow increases US GDP by 0.7 percentage points after eight quarters. Additionally, we find that one standard deviation shocks to portfolio debt inflow and portfolio equity inflow increase US GDP by 0.5 and 0.4 percentage points, respectively, after two years. Local projection and standard VAR impulse responses show similar effects on US GDP two years after capital inflow shocks. Finally, our FAVAR results indicate that US GDP responses to capital inflow shocks remain positive and significant despite the inclusion of US monetary policy factors.

The primary contribution of this study is empirically supporting the hypothesis that portfolio inflows have been beneficial to the US economy. We use disaggregated US financial accounts data to study not only the effect of portfolio inflow and its components, debt and equity, on US GDP but also how shocks to their sub-categories such as US corporate debt and US government debt impact the US economy in the long-run. The estimates show positive long-term effects across most categories. Our approach to use structural VAR models to allow for feedback effects rather than single equation instrumental variables (i.e. Blanchard et al. (2016), Durham (2003) and Prasad et al. (2007)) enables us to estimate the dynamic effects of capital inflow on US GDP. Additionally, we carefully check for the sensitivity of our estimates. We address the sensitivity of standard impulse responses to misspecification as suggested by Kilian (2001) and estimate local projection impulse responses robust to VAR model misspecifications. We also 
check for omitted variable bias by adding US interest rates to our core VAR variables. We use factor-augmented VAR models to show that our main results hold even after controlling for US monetary policy effects.

The rest of this chapter is structured as follows: In section 1.2, we present the empirical background on international capital flows. In section 1.3, we explain structural VARs and identification strategies that we use to study dynamic effects of foreign investment and its components on US GDP. In section 1.4, we describe data sources available on international capital flow and foreign investment, focusing on the data series we use and their characteristics. In section 1.5, we present the impulse responses associated with structural VARs. We present the local projection impulse responses in section 1.6. We add five US interest rates and use the FAVAR method to investigate the effect of US monetary policy on our main results and report the impulse responses in section 1.7. We conclude in section 1.8 .

\subsection{Empirical Background on International Capital Flows}

In this section, we discuss multiple aspects of international capital flows. Section 1.2.1 overviews different capital flow variables used in the literature. We compare different components of foreign investment in the US and how they have changed over time in section 1.2.2. Finally, we describe the recent literature about the effect of capital flow on growth in section 1.2.3.

\subsubsection{Capital Flows: Net versus Gross}

To study the effect of capital inflow we first need to define capital inflow. There are different series used in the literature to measure capital inflow. In earlier studies, the current account deficit was used. For example, Higgins and Klitgaard (1998) consider the US current account deficit as a measure for US capital inflow. They suggest that US current account deficits should be seen as net capital inflows that promote growth in the United States. They argue that US 
economy benefits from the inflow of foreign capital because it allows domestic investments to increase even if private savings are decreasing. Conversely, Obstfeld (2012) highlights the fact that there is an undeniable relationship between current account imbalances and global financial instability. Moreover, he emphasizes the importance of considering both current account imbalances and gross international financial flows in assessing financial stability risks.

Capital flow literature is divided between studies that only focus on net capital inflows and papers that consider both net and gross capital inflows. Ferreira and Laux (2009) and Aizenman et al. (2010) belong to the former group. Ferreira and Laux (2009) study the impact of net portfolio flows on growth of 50 countries and show that openness to portfolio flows have positive effects on economic growth. Aizenman et al. (2010) study the effect of external financing, including net FDI inflows, net portfolio inflows and net bank lending inflows, on output volatility in developing countries. They find higher net portfolio inflows and net bank lending inflows increase a country's likelihood of output volatility.

Studies belong to the latter group either consider both net and gross capital inflows or only focus on gross inflows. Broner et al. (2013) study the behavior of gross capital flows during financial crises. They show that gross capital flows are more volatile and more pro-cyclical compared to net capital flows. They find that gross inflows and gross outflows both shrink during crises. Forbes and Warnock (2012) differentiate gross capital inflow from gross capital outflow in their study of the dynamics of capital flow waves. They explain that domestic and foreign investors can respond differently to shocks as they face different exposures to domestic exchange rate or have different access to liquidity. 
We follow recent literature by using gross capital inflow variables instead of net. The only difference is that we use US financial accounts level data instead of flow data. Our dataset is disaggregated and allows us to investigate the effect of each category on US GDP.

\subsubsection{US Capital Flows}

Total foreign investment in the US reached $\$ 24.5$ trillion by the end of the first quarter of 2017. ${ }^{3}$ The following figures help us understand how foreign investment and its components have changed over time.

Figure 1-1 shows how foreign investment positions in the US have changed over time. There are two points to note. Firstly, net foreign investment in the US grew significantly after financial crisis and it reached $\$ 5.8$ trillion dollars in 2016 Q1. Secondly, since 2008 the gap between capital inflow and outflow has continued to widen. In the first quarter of 2016 gross capital inflow and outflow level were $\$ 23.2$ and $\$ 17.3$ trillion dollars, respectively.

The current value of US assets held by foreigners reached the value of US nominal GDP in 2010 Q1 and has outgrown US output ever since. That is a crucial point that could be overlooked if one only looks at the net capital inflow in their analysis. Figure 1-2 portrays components of capital inflow level as percentage of gross capital inflow level. Portfolio investment level has shot up since mid-1990s whereas FDI and bank lending inflow shares decreased over time. It is clear that the main contributor in the growth of total foreign investment in the US is the portfolio investment component. Figure 1-3 shows that portfolio investment accounts for more than 70 percent of total foreign investment in the US between 2011 and 2016 compared to only 54 percent

3 That is the lower bound of total foreign investment where foreign direct investment is valued on current-cost basis. If foreign direct investment is measured at market-value, total US liabilities for the same period goes up to almost $\$ 33$ trillion according to US Bureau of Economic Analysis (BEA). 
between 1977 and 1990. This confirms that the level of foreign portfolio investment in the US has grown significantly compared to FDI and bank credit level.

Now we study whether all components of portfolio investment contribute to this surge equally. Figure 1-4 answers that question by plotting debt and equity inflows as a percentage of portfolio investment level. The debt component is dominant and in the first quarter of 2016 is accounted for more that 60 percent of foreign portfolio investment in the United States.

Although both equity and debt sit in the liabilities section of financial accounts they are very different in nature. Equity accounts for the value of US stocks owns by foreigners who can claim them at any given time. Also, stock holders share profits and losses through fluctuations in stock price and dividends. Debt portion of portfolio investment, however, includes US corporate and government debts and their associated interest rates that need to be paid in full at some point in the future.

The continuous increase in debt portion of portfolio investment raises the question whether US debt level is sustainable. Haque et al. (2015) examine sustainability of US current account deficit. They show that multiple factors such as economic conditions in the rest of the world and in China and valuation effects can impact sustainability of US external debt. The authors consider different debt measurements and report that while debt to GDP ratio seems sustainable, debt to government spending appears unsustainable. Evans (2017) studies the accumulation of external debt in the US and shows that the growing net foreign liability moved toward steady state before 1990s and away from steady state since mid 1990s. His model reveals that increasing net foreign liability and declining net export to GDP ratio could only be sustainable if agents expected that US current account would improve significantly in the near future. His findings are in line with earlier papers (see Evans (2017)'s references such as Summers, 2004; Obstfeld and Rogoff, 2007 
and Backus et al., 2009) that conclude current account deficit cannot go on indefinitely and eventually either net exports should increase, or agents will adjust their expectations.

Another important question is how the increasing US external debt affects US growth. Does US government debt and US corporate debt have similar effects on US GDP? We find that a positive shock to US external debt has a positive effect on US output. However, it is US corporate debt that carries the larger portion of that positive effect. Therefore, it seems that US corporate debt is growing as a necessity for US growth rather than a burden.

\subsubsection{Capital Flows, Growth and Comparison with This Study}

There is a division between the effect of capital inflow on growth that theory suggests and what policy makers in emerging economies believe (Blanchard et al., 2016). Theory suggests that an increase of capital inflow into a country with flexible exchange rate policy puts upward pressure on domestic currency. Therefore, domestic currency appreciates, and the country's current account deteriorates, reducing GDP if the money supply remains unchanged. In practice, an ongoing flow of foreign capital into a country also puts downward pressure on domestic interest rates, elevating investment and output.

Capital flows in general and portfolio flows in particular are regarded as cause for concern in the literature. Magud, Reinhart and Rogoff (2011) break down the reasons behind capital controls to four fears: fear of appreciation, fear of hot money, fear of large inflows and fear of loss of monetary autonomy. De la Torre, Didier and Pienknagura (2012) highlight that instability and uncertainty associated with capital flow fluctuations can have long-lasting adverse effects on income.

Durham (2003) examines the effect of foreign portfolio investment and bank lending on economic growth of 88 countries from 1977 to 2000. His estimations show that portfolio 
investments and foreign bank lending have negative impacts on growth. However, he mentions that his results might be affected by simultaneity bias given the use of simultaneous equations. The author shows that one percentage point increases in the ratio of portfolio investments to GDP and foreign bank lending as percentage of GDP reduce average growth rates by 1.4 and 0.2 percentage points, respectively. We use structural VAR where each variable is a linear function of lags of itself as well as lags of all other variables. This method allows us to study the effect of structural shocks to foreign portfolio investment and its components on US GDP.

Prasad et al. (2007) show that among 59 nonindustrial countries those that relied less on foreign capital have grown faster than those that have relied more. They also argue that underdeveloped financial markets are the main obstacles that prevent developing economies from channeling the foreign capital into the local economy efficiently. They conclude that developing countries would benefit from slow and cautious capital integrations when they are open to the type of capital that their economies are capable to absorb and more vigilance toward less absorbable foreign capital. Meanwhile, local financial markets might benefit from a grace period that allows them to develop before liberalization of capital movements. Their estimations show that if current account balance improves by one percentage point, economic growth goes up by around 0.1 percentage point. It is important to note that their findings are mainly for nonindustrial countries.

Prasad et al. (2007)'s argument that underdeveloped financial markets in developing countries is the main reason why they struggle to fully absorb the benefits of financial liberalization stresses the importance of studying the impact of capital flows on developed countries like the United States. By looking at the effect of foreign capital on the US economy, developing countries can project the benefit of financial development against its potential cost and make informed decisions on financial liberalization. 
Warnock and Warnock (2009) study the effect of international capital inflow on US longterm interest rates by looking at the effect of foreign-purchased US government bonds on 10-year Treasury yield. They predict that if there were no foreign purchases of US government bonds for one year, long-term rates would have been 80 basis points higher. They also find similar effects on US mortgage rates and other long-term interest rates. Warnock and Warnock only focus on the effect of US government bonds held by foreigners whereas we look at various components of foreign investments in the United States. Their study was conducted before the recent financial crisis, so it does not include post-financial crisis period. Our sample covers pre- and post- financial crisis.

Ferreira and Laux (2009) examine the impact of portfolio flows on growth of 50 countries, including advanced and less-developed countries, from 1988 to 2000 . They find that openness to portfolio flows has positive effects on economic growth. They show that positive effects of net equity inflow on growth is greater for less-developed countries. They report that one percent increase in the lagged net sale of local equities by local residents increases advanced and developing countries' GDP growth by 0.2 and 3.2 percentage points, respectively. They mainly focus on the effect of net portfolio flows on growth. Our study concentrates on the effect of gross portfolio inflow and its components. Our sample also includes the recent financial crises.

Aizenman et.al (2013) study the effect of international capital flows on economic growth of 100 countries between 1990 and 2010. They find a significant and stable relationship between FDI and growth. However, the relationships between portfolio flows and growth are shown to be less stable. They find one standard deviation increase in FDI inflow and outflow increase growth rate of GDP per capita by 1.8 and 12.1 percentage points, respectively. Aizenman et al. (2013) also show that one standard deviation increases of FDI inflow, equity investment and short-term debt 
during pre-crisis period increase GDP per capita growth by $0.9,0.4$ and zero percentage points, respectively.

Blanchard et al. (2015) develop an extension to the Mundell Fleming model to study whether an increase of capital inflow has a positive or a negative effect on economic growth. They show that dividing the capital inflow into bond flows and non-bond flows can explain the conflict between theory and what policymakers believe. Their empirical results show that increases in nonbond flows and bond flows have positive and negative impacts on output, respectively. They use instrumental variables to resolve the endogeneity issue. In this chapter, we use structural VAR models where all variables are assumed to be endogenous. An important contribution of this study is to use disaggregated quarterly data that covers the pre- and post-financial crisis period, so we can study the effect of shocks to sub-categories of capital inflow on US GDP.

\subsection{Structural VAR Models}

There is significant evidence in literature suggesting that domestic GDP is one of the main determinants of capital inflow into a country (e.g. De Vita and Kyaw (2008)). There are also studies that investigated the effect of capital inflow on domestic economy and found significant results (e.g. Blanchard et al. (2016)), so feedback effects are important. In this chapter, we use a structural VAR model where all variables are assumed to be endogenous. Structural VAR allows us to study the dynamic effects of foreign investment shocks on US output. Each model contains lags of US GDP growth on the right hand-side, including trade variables as components of GDP. Therefore, the estimated effects are beyond the effects of trade on US GDP growth. In our models, we identify shocks that are exogenous and independent of each other and find out how they impact US GDP. 
A Vector Autoregression (VAR) model introduced by Sims (1980), can be explained as a system of linear multivariate regressions where all variables are treated as endogenous and each variable is a function of lagged values of all other endogenous variables in the system. Our reduced form VAR models are based on quarterly data from 1980 Q1- 2016 Q1 and are defined as follows: $Y_{t}=C_{0}+C_{1} Y_{t-1}+C_{2} Y_{t-2}+\cdots+C_{p} Y_{t-p}+e_{t}$

Where $\boldsymbol{Y}_{t}=\left(y_{1 t}, y_{2 t}, \ldots y_{n t}\right)^{\prime}$ is a vector of $n$ variables at time $t, \boldsymbol{C}_{0}$ is a $(n \times 1)$ vector of constants, $\boldsymbol{C}_{1}, \boldsymbol{C}_{2}$ and $\boldsymbol{C}_{p}$ are $(n \times n)$ matrices of coefficients and $\boldsymbol{e}_{t}$ is a $(n \times 1)$ vector of residuals where $E\left[\boldsymbol{e}_{t}\right]=0$ and $E\left[\boldsymbol{e}_{t} \boldsymbol{e}_{\tau}^{\prime}\right]= \begin{cases}\Omega, & \text { if } t=\tau \\ 0 & \text { otherwise }\end{cases}$

An important specification issue when we use VAR is stationarity. Therefore, we use growth rate of all variables, that are stationary, in our VARs. Also, all VAR models in this chapter include 4 lags which seem to be appropriate for quarterly data. Our results remain unchanged when we use AIC suggested lag length. Structural VAR is then defined as follow:

$A_{0} Y_{t}=\alpha+\sum_{i=1}^{4} A_{i} Y_{t-i}+\varepsilon_{t}$

Where $\boldsymbol{Y}_{t}=\left(y_{1 t}, y_{2 t}, \ldots y_{n t}\right)^{\prime}$ is a vector of $n$ variables at time $t$ and $\boldsymbol{\varepsilon}_{t}$ represents the vector of structural innovations that are serially and mutually uncorrelated. If we left multiply the equation (1.2) by $\boldsymbol{A}_{0}^{-1}$, we obtain the reduced form VAR with a similar format as equation (1.1). $\boldsymbol{A}_{0}^{-1}$ has a recursive structure which is designed to decompose the reduced form errors $\boldsymbol{e}_{t}$ to exogenous structural shocks $\varepsilon_{t}$.

$e_{t}=A_{0}^{-1} \varepsilon_{t}$

To estimate a Structural VAR, we need to start with the reduced-form VAR and solve for structural parameters to find matrix $\boldsymbol{A}_{0}$. 
Once we identify the structural VAR, we find impulse responses to each structural shock. To achieve this, we need to transform our structural VAR so our endogenous variables are defined as a sum of structural shocks:

$Y_{t}=\mu+\sum_{i=0}^{\infty} \Psi_{i} A^{-1} \varepsilon_{t-i}$

Where $\boldsymbol{\mu}=\boldsymbol{C}(\boldsymbol{L})^{-1} \boldsymbol{C}_{\mathbf{0}}$ and $\boldsymbol{\Psi}_{i}$ represents $(n \times n)$ coefficient matrix of reduced form errors $\boldsymbol{e}_{\boldsymbol{t}}$ in the Vector Moving Average (VMA) format. ${ }^{4}$ For each part of this chapter we first explain $\boldsymbol{Y}_{t}$ variables included and then show the recursive structure used to decompose the reduced form errors.

Ramey (2016) explains characteristics of structural shocks as follows: "(1) they should be exogenous with respect to other current and lagged endogenous variables in the model; (2) they should be uncorrelated with other exogenous shocks and (3) they should represent either unanticipated movements in exogenous variables or news about future movements in exogenous variables." Structural shocks estimated in this chapter are consistent with Ramey (2016)'s definition of structural shocks.

\subsubsection{Model 1: US GDP and Net Capital Inflow}

Earlier studies focused on net capital inflow to measure the effect of foreign capital on growth. Therefore, in our first model we study the effect of net foreign investments in the US on US output for comparison purposes.

US GDP is US GDP growth and net capital inflow measures the growth of net foreign investment in the US. Net foreign investment in the US is defined as the gross US assets held by foreigners

${ }^{4} \boldsymbol{C}(\boldsymbol{L})$ is defined as $\boldsymbol{C}(\boldsymbol{L})=\left(\boldsymbol{I}_{n}-\boldsymbol{C}_{1} \boldsymbol{L}-\boldsymbol{C}_{2} \boldsymbol{L}^{2}-\cdots-\boldsymbol{C}_{p} \boldsymbol{L}^{p}\right)$ where $\boldsymbol{L}, \boldsymbol{L}^{2}, \ldots, \boldsymbol{L}^{p}$ are lag operators 
less the gross foreign assets held by US residents. Our structural VAR follows the equation (1.2) and the decomposition of reduced form errors $\boldsymbol{e}_{t}$ follows equation (1.3):

$$
\boldsymbol{e}_{t} \equiv\left(\begin{array}{c}
e_{t}^{U S G D P} \\
e_{t}^{\text {net capital inflow }}
\end{array}\right)=\left[\begin{array}{ll}
a_{11} & 0 \\
a_{21} & a_{22}
\end{array}\right]\left(\begin{array}{c}
\varepsilon_{t}^{U S \text { GDP shock }} \\
\varepsilon_{t}^{\text {net capital inflow shock }}
\end{array}\right)
$$

We assume that US GDP growth does not respond to net capital inflow innovations within the same quarter. Capital inflow affects domestic output through two channels, exchange rate and interest rate. Based on exchange rate channel, higher capital inflow turns into higher demand for local currency which creates an upward pressure on price of local currency, US dollar in our case. Appreciation of US dollar makes US goods and services more expensive abroad and foreign goods and services cheaper in the United States. Therefore, US balance of payment deteriorates and US output decreases.

The interest rate channel focuses on the impact of capital inflow on domestic interest rates. As foreign capital flows into the US the demand for US assets grows which creates a downward pressure on domestic interest rates. Lower domestic interest rates reduce the cost of borrowing in the US and promote investment and output. These effects will not be instant. Therefore, it is plausible to assume that the effects of capital inflow on US GDP will not occur within the same quarter. Net capital inflow innovations that have not been explained by GDP growth shocks will be included on net capital inflow shocks. The assumption that US output does not contemporaneously respond to capital flow innovations holds throughout this chapter.

\subsubsection{Model 2: US GDP, Gross US Assets Held by Foreigners and Gross Foreign Assets Held by} US Residents.

In this model, we study how US output responds to gross capital inflow shocks compared to gross capital outflow shocks. Gross capital inflow measures growth of total US assets held by foreigners and gross capital outflow measures growth of total foreign assets held by US residents. 
Structural VAR follows equation (1.2) form and the decomposition of reduced form errors $\boldsymbol{e}_{t}$ follows equation (1.3):

$$
\boldsymbol{e}_{t} \equiv\left(\begin{array}{c}
e_{t}^{U S \text { GDP }} \\
e_{t}^{\text {gross capital inflow }} \\
e_{t}^{\text {gross capital outflow }}
\end{array}\right)=\left[\begin{array}{lll}
a_{11} & 0 & 0 \\
a_{21} & a_{22} & a_{23} \\
a_{31} & a_{32} & a_{33}
\end{array}\right]\left(\begin{array}{c}
\varepsilon_{t}^{\text {US GDP shock }} \\
\varepsilon_{t}^{\text {gross capital inflow shock }} \\
\varepsilon_{t}^{\text {gross capital outflow shock }}
\end{array}\right)
$$

We allow capital inflow and outflow to respond to each other's innovations contemporaneously. As a result, we require one more assumption for identification purposes. Thus, we assume $a_{23}=a_{32}$ so capital inflow and outflow affect each other contemporaneously and in equal magnitudes. This assumption seems to be in line with the co-movements observe in capital inflow and capital outflow series.

\subsubsection{Model 3: US GDP, Foreign Direct Investments (FDI) in the US, US Portfolio Assets Held} by Foreigners and Foreign Bank Lending.

This model focuses on the components of US assets held by foreign investors and how they affect US GDP. FDI inflow is FDI growth, portfolio inflow measures the growth of portfolio investments held by foreigners and bank credit inflow is the growth of foreign bank lending.

The setup of the structural VAR is the same as equation (1.2) and $\boldsymbol{e}_{t}$ follows equation (1.3):

$$
\boldsymbol{e}_{t} \equiv\left(\begin{array}{c}
e_{t}^{\text {US GDP }} \\
e_{t}^{\text {fdi inflow }} \\
e_{t}^{\text {portfolio inflow }} \\
e_{t}^{\text {bank credit inflow }}
\end{array}\right)=\left[\begin{array}{llll}
a_{11} & 0 & 0 & 0 \\
a_{21} & a_{22} & 0 & 0 \\
a_{31} & a_{32} & a_{33} & a_{34} \\
a_{41} & a_{42} & a_{43} & a_{44}
\end{array}\right]\left(\begin{array}{c}
\varepsilon_{t}^{\text {US GDP shock }} \\
\varepsilon_{t}^{\text {fdi inflow shock }} \\
\varepsilon_{t}^{\text {portfolio inflow shock }} \\
\varepsilon_{t}^{\text {bank credit inflow shock }}
\end{array}\right)
$$

We assume that US GDP growth does not respond to capital inflow innovations contemporaneously. Capital inflow innovations in this part include FDI innovations, portfolio innovations and bank credit innovations. We assume these innovations only affects US GDP growth with a lag. We also assume FDI inflow does not respond to portfolio innovations and bank 
credit innovations contemporaneously. That is not far from reality because FDI is mainly seen as a long-term investment that does not fluctuate significantly in response to temporary changes. Thus, we can assume any portfolio or bank credit innovations only affect FDI with a lag.

Portfolio investments and bank credits are fairly liquid and more responsive to shocks than FDI. Therefore, we assume that portfolio inflow responds to bank credit inflow innovations contemporaneously and vice versa. This assumption means $a_{34}=a_{43}$ which allows portfolio and bank credit inflows to respond to each other's shocks contemporaneously and with equal magnitudes.

\subsubsection{Model 4: US GDP, US Equity Portfolio and US Debt Portfolio Held by Foreigners}

This model concentrates on how US GDP growth responds to shocks to equity and debt inflows, two components of portfolio inflow. Equity inflow measures growth rate of US equity and investment fund shares held by foreign investors, and debt inflow is growth rate of US debt held by foreign investors. Equity and investment fund shares held by foreigners include US corporate equity, money market fund shares and mutual fund shares. US debt held by foreigners consists of US corporate debt and US government debt. The structural VAR follows equation (1.2) where $\boldsymbol{e}_{t}$ has the following format:

$$
\boldsymbol{e}_{t} \equiv\left(\begin{array}{c}
e_{t}^{U S G D P} \\
e_{t}^{\text {equity inflow }} \\
e_{t}^{\text {debt inflow }}
\end{array}\right)=\left[\begin{array}{lll}
a_{11} & 0 & 0 \\
a_{21} & a_{22} & a_{23} \\
a_{31} & a_{32} & a_{33}
\end{array}\right]\left(\begin{array}{c}
\varepsilon_{t}^{U S \text { GDP shock }} \\
\varepsilon_{t}^{\text {equity inflow shock }} \\
\varepsilon_{t}^{\text {debt inflow shock }}
\end{array}\right)
$$

We assume that US GDP does not respond to equity inflow or debt inflow innovations within the same quarter. We also assume that debt inflow and equity inflow respond to each other's innovations contemporaneously. This assumption is imposed by $a_{23}=a_{32}$ so we are able to estimate the extra unknown parameter. This assumption is also in line with the fact that equity and bond markets operate on a daily basis, so investors have access to daily information such as interest 
rates, yields and prices. Consequently, investors operating in these markets can observe unexpected changes and respond to them swiftly.

\subsubsection{Model 5: US GDP, US Government and Corporate Debt}

In this model, we examine the response of US output to shocks to US government debt inflow and US corporate debt inflow, two components of portfolio debt inflow. US government debt measures growth of US government debt held by foreigners and US corporate debt measures growth of US corporate debt held by foreigners. US government debt includes Treasury securities, US agency and government sponsored enterprise (GSE)-backed securities and municipal securities. US corporate debt contains US corporate bonds and open market paper. Structural VAR follows equation (1.2) and $\boldsymbol{e}_{t}$ can be defined as follows:

$$
\boldsymbol{e}_{t} \equiv\left(\begin{array}{c}
e_{t}^{U S G D P} \\
e_{t}^{\text {US government debt }} \\
e_{t}^{\text {US corporate debt }}
\end{array}\right)=\left[\begin{array}{lll}
a_{11} & 0 & 0 \\
a_{21} & a_{22} & 0 \\
a_{31} & a_{32} & a_{33}
\end{array}\right]\left(\begin{array}{c}
\varepsilon_{t}^{U S \text { GDP shock }} \\
\varepsilon_{t}^{\text {US government debt inflow shock }} \\
\varepsilon_{t}^{\text {US corporate debt inflow shock }}
\end{array}\right)
$$

US GDP does not respond to US debt innovations within the same quarter. We assume that US government debt held by foreigners does not respond to US corporate debt innovations within the same quarter. Therefore, US corporate debt innovations that cannot be explained by US output shocks or US government debt shocks reflect shocks to US corporate debt held by foreigners.

\subsection{Data}

There are three main sources that offer US capital flow data. IMF databases, International Financial Statistics (IFS) and Balance of Payments and International Investment Position Statistics (BOP/IIP), are popular sources in capital flow literature. They are particularly useful for panel data studies as they contain both quarterly and annual data from numerous developed and developing countries. Apart from the main components of capital flow, BOP database also contains 
subcategories that form each component. Compared to IMF databases, our data source goes one step further as it also includes data on components of portfolio equity and debt. Another benefit of our source is that it contains data on flows as well as levels for each category.

First source is US International Transactions data from Bureau of Economic Analysis (BEA). The series in this dataset match with IMF BOP data, the only difference is that the extended details on US financial account starts from 1999 Q1 whereas IMF datasets goes back to 1970s. However, IMF highlights the fact that there is a break in comparability of data in 1999 Q1. That means the data reported after 1999 Q1 does not form a consistent series with the data reported prior to that date. That will only affect subcategories of capital flow's main components such as equity and debt instruments. BEA has also reported quarterly data on US International Investment Position (IIP) since 2006. Those series are too short for our time series analysis.

Second US-specific source is Treasury International Capital System (TIC). TIC data do not cover data on FDI flows but they cover most components of international financial flows. TIC monthly data are cross-border financial flows to and from US reported by broker/dealers of securities, banks and other market participants. TIC monthly and annual holdings data are reported by US custodians of securities, issuers of US securities in foreign countries and US investors in foreign securities that do not use US custodians ${ }^{5}$.

Finally, the third source, and the one that we use for this chapter, is Financial Accounts of the United States- Z.1 tables- that are available from Board of Governors of the Federal Reserve System's website. This source contains two sets of data series that are associated with US financial relations with the rest of the world. The first set, the one we use for this chapter, is presented in table L.133 Rest of the World and contains series on the levels of various US assets held by

\footnotetext{
${ }^{5}$ For more details on TIC data please visit: https://www.treasury.gov/resource-center/data-chart-center/tic
} 
foreigners and foreign assets held by US residents at the end of each quarter. The second set is presented in table F.133 Rest of the World and include series on the flows of assets and liabilities between US residents and foreign investors in each quarter. In financial accounts flow of assets means the exchange of assets, so this table is equivalent to transaction of assets and liabilities in each quarter.

The difference between level and flow datasets are well explained in Board of Governors of the Federal Reserve System's website:

"In the SNA2008, the change in the level from one period to the next is called the "economic flow," and can be decomposed into three broad elements: transactions, which measure the exchange of assets; revaluations, which measure changes in market value of untraded assets; and other changes in volume, which measure discontinuities or breaks in time series due to disaster losses or a change in source data or definition. In the "Financial Accounts," "flows" refer to the exchange of assets, corresponding to the SNA definition of transactions, that is, "flow tables" in the "Financial Accounts" are equivalent to "transaction tables" in the SNA terminology. In practice, other volume changes are relatively rare, and revaluations occur only for series carried at market value (such as corporate equities and mutual fund shares), so for many series the change in the level is equal to the flow."

There are benefits to using this source. First of all, it contains quarterly data of more than five decades which reduce our concern over small sample size bias problem. Secondly, the financial accounts for the rest of the world has more details than any other datasets that we mentioned earlier. This characteristic allows us to investigate the role that each sub-category plays

\footnotetext{
${ }^{6}$ For more information, please visit:

https://www.federalreserve.gov/releases/z1/current/html/introductory_text.htm
} 
on US growth. This study is the first to study how shocks to components of foreign portfolio investment and its subcategories affect US GDP. It is important to note that financial accounts data does not categorize capital inflows and outflows in a conventional way. It shows financial assets and liabilities of rest of the word in relation to the US and it breaks down the components of each category. Unlike BEA data that explicitly identifies FDI, portfolio and bank credit, FRB's database only identifies FDI explicitly, but it contains series that can be categorized either as portfolio investment or bank credit based on how they are calculated. For this chapter, we use this dataset and we calculate portfolio investments and bank credits using the details provided on each series. Appendix 1 contains a flow chart showing the relationship between capital inflow variables and their components.

Apart from capital flow variables, we also collect US nominal GDP from BEA and US CPI from Federal Reserve Bank of St. Louis (FRED). All variables are corrected for inflation and are in real terms. Since all variables have unit roots we use growth rates of them in our models that are stationary ${ }^{7}$. A brief description of the capital flow variables and descriptive statistics of all variables are presented in Table 1-1 and Table 1-2, respectively.

\subsection{Primary Empirical Results}

In this section, we present impulse responses associated with each structural VAR model introduced in section 1.3 . We only report the accumulated responses that can be interpreted as the long-term effect on US GDP. We are interested in the first row of each panel as they present the effect of capital flow variables on US GDP. Since all our variables are in growth rate format, the unit of each vertical axis is percentage point.

\footnotetext{
${ }^{7}$ Unit root test results for all variables are reported in Appendix 2
} 
Figure 1-5 captures impulse responses for the first model where we study the effect of net foreign investment in the US on US output. A positive one standard deviation shock to net capital inflow has a small positive effect of 0.1 percentage point on US GDP growth after eight quarters. This small positive effect is statistically insignificant.

The impulses responses for the second SVAR are displayed in Figure 1-6. This model compares US GDP responses to gross capital inflow and gross capital outflow shocks. A one standard deviation shock to total US assets held by foreigners have a positive and statistically significant effect on US output. The long-run effect of this shock on US GDP eight quarters after it occurs is 0.5 percentage points. A positive shock to total foreign assets held by US residents has a small positive but statistically insignificant effect on US output growth after two years.

Figure 1-7 displays responses of the third model and illustrates US GDP responses to shocks to FDI, portfolio and bank credit inflows. A positive shock to portfolio inflow has a positive and significant effect on US output. A one standard deviation increase in portfolio inflow raises US GDP by 0.7 percentage points after eight quarters. One standard deviation of portfolio inflow equals $\$ 570$ billion in 2016 Q1. Therefore, the multiplier equals 0.23 for portfolio investment. A positive shock to bank credit inflow has a very small positive but insignificant effect on US output. Our results are different from Durham (2003)'s, where foreign portfolio investments are found to have no effect on growth. He also shows that foreign bank lending has a negative effect on growth. His sample include both developed and developing economies, which could be one possible reason for why our results are different.

Finally, we find that a positive shock to FDI inflow has a negative but insignificant effect on US GDP growth in the long-run. The negative effect of FDI growth on US GDP growth is 
puzzling. Most studies that focus on the effect of FDI on growth use FDI flows variables. ${ }^{8}$ Our dataset reports FDI levels based on current cost, the value of assets at the time of purchase. As a result of that, FDI series used in this study are different compared to FDI series reported by BEA or IMF, which are based on market value. We suspect that might be the reason for the unexpected negative sign of FDI effect on US output growth. Figure 1-8 portrays the difference between the two measurements of FDI, current cost and market value, over time and shows that the gap between these two measures have indeed widened over time.

BEA International Investment Position (BEA IIP) data contains both current cost and market value measures of FDI. However, its quarterly series only go back to 2006 so we repeat the third SVAR using BEA IIP annual data instead. The annual VAR is based on one lag and impulse responses are calculated up to five years. Figure 1-9 shows impulse responses for the third model based on BEA IIP annual data. A positive shock to FDI growth has a positive effect of 0.8 percentage points on US output growth after two years. The positive effect of FDI inflow on US output is in line with what we expect from the literature. Thus, we conclude that the FDI negative sign we found earlier is mainly due to the use of FDI current cost data.

Figure 1-10 portrays impulse responses of US GDP to equity and debt inflow shocks as described in the fourth SVAR. A positive shock to equity inflow has a positive and partially significant effect on US output growth. A one standard deviation shock to portfolio equity inflow increases US output by 0.4 percentage points after eight quarters. One standard deviation of equity inflow equals $\$ 514$ billion in 2016 Q1. Thus, the multiplier for equity investment is 0.14 . Our estimate is in line with Blanchard et al. (2015)'s estimations. They show that one percent increase

${ }^{8}$ See Iwasaki and Tokunaga (2014)'s for further references on this issue. 
of portfolio equity flows as percentage of GDP increases GDP growth by 0.5 percentage points. Moreover, we find that a positive shock to debt inflow have a positive and statistically significant impact on US output. A one standard deviation improvement in portfolio debt inflow increases US GDP growth by 0.5 percentage points after two years. One standard deviation of debt inflow is \$276 billion in 2016 Q1. Therefore, the multiplier equals 0.33 for debt inflow.

Figure 1-11 illustrates impulse responses for the fifth model, impulse responses of US output to shocks to US government debt and US corporate debt. A positive shock to US corporate debt has a positive and significant effect on US GDP growth. Within two years, US GDP increases by 0.7 percentage points in response to a one standard deviation shock to US corporate debt inflow. One standard deviation of US corporate debt inflow equals \$144 billion in 2016 Q1. Therefore, the multiplier for US corporate debt inflow is 0.89. A positive shock to US government debt inflow has a positive but statistically insignificant impact on US GDP growth. One standard deviation of US government debt inflow equals \$218 billion in 2016 Q1. Thus, the multiplier for US government debt inflow is 0.25 . US corporate debt inflow has the highest multiplier among subcategories of portfolio investment.

Our analysis shows that shocks to foreign portfolio investments have positive and significant impact on US GDP growth in the long-run.

\subsection{Results from Local Projection Method}

Standard VAR impulse responses can be sensitive to lag-order choice. Kilian (2001) explains that the effects of overfitting and underfitting of a VAR model on impulse responses are asymmetric. He compares the impulse responses point estimates and confidence intervals resulted from different information criteria and concludes that VAR models with lag-order based on parsimonious criteria such as SIC and HQC perform well at short horizons but perform poorly at 
longer time horizons. He also shows that models with lag-order based on more balanced criteria such as AIC perform well at both short and long horizons.

In this section, we use local projection method to re-estimate impulse responses for each model described in the previous section. Jordà (2005) introduces local projection impulse response function (LPIRF) that is robust to misspecifications. In this method, impulse responses are calculated based on a series of regressions that have lead orders of endogenous variable on their left-hand side. This method has helped researchers calculate impulse responses that are more robust to lag misspecifications compared to standard VAR impulse responses.

Jordà (2005) uses the following notation to describe how $\boldsymbol{y}_{t+S}$ is projected onto the linear space of lag orders of $\boldsymbol{y}_{t}$ :

$y_{t+s}=\alpha^{s}+B_{1}^{s+1} y_{t-1}+B_{2}^{s+1} y_{t-2}+\cdots+B_{p}^{s+1} y_{t-p}+u_{t+s}^{s}$

$s=0,1,2, \ldots, h-1$

Where $\boldsymbol{y}_{t+s}$ is the projection of $\boldsymbol{y}$ at horizon $t+s, \boldsymbol{\alpha}^{s}$ is an $n \times 1$ vector of constants and $B_{i}^{s+1}$ represents matrices of coefficients for each lag $i$ and horizon $s+1$. There will be one regression for each value of $s$ and local projections include $h$ regressions computed using equation (1.5). It is important to note that when $s=0$ equation (1.5) is the same as a standard VAR. ${ }^{9}$ LPIRF can then be estimated by:

$\widehat{I R}\left(t, s, d_{i}\right)=\widehat{B}_{1}^{s} d_{i} \quad s=0,1,2, \ldots, h-1$

Where $\boldsymbol{d}_{i}$ represents the shocks and $B_{1}^{0}=\boldsymbol{I}$ for $s=0$.

\footnotetext{
${ }^{9}$ Ronayne (2011) points out that Jordà (2005) original notation $s=0,1,2, \ldots, h$ will lead to $h+1$ regressions where in fact the total number of regressions should be $h$ as Jordà (2005) specified. We address the issue in equation (1.5).
} 
Kilian and Kim (2009) compare bias and variance of impulse responses from standard VAR and local projection models. They argue that local projection estimators have higher bias and variance in small samples and as the sample size grows the bias of local projection estimators shrinks but their asymptotic intervals become significantly wider than standard VAR ones. They reject that local projection confidence intervals are more accurate than standard VAR intervals.

In defense of local projection methods, Ronayne (2011) compares standard VAR impulse responses with local projection impulse responses and finds that they diverge after horizons higher than the lag length used in associated VARs. He shows that the bias of standard VAR impulse responses increases in longer horizons and suggests including local projection impulse responses especially when one studies long-run effects. Therefore, in this section, we estimate local projection responses for the models we explained in section 1.3 and compare the standard VAR impulse responses with local projection ones for the variables of interest.

Local projection and standard VAR impulse responses of US GDP to a positive shock to portfolio inflows are shown in Figure 1-12. Panel A shows local projection and standard VAR impulse responses of US GDP to a positive shock to portfolio inflow and Panel B compares the accumulated impulse responses obtained from the two methods. LPIRF shows that a one standard deviation shock to portfolio inflow increases US GDP by 0.5 and 0.9 percentage points after 8 and 14 quarters, respectively. LPIRF is close to our standard VAR impulse responses where a positive shock to portfolio inflow increases US output by 0.7 percentage points after two years.

Figure 1-13 shows local projection and standard VAR impulse responses of US GDP to shocks to equity and debt inflows, components of portfolio inflow. Panel A and Panel B show impulse responses and accumulated impulse responses of US GDP to equity and debt inflow shocks, respectively. LPIRF displays that a one standard deviation increase in portfolio equity 
inflow increases US GDP by 0.3 and 0.6 percentage points after 8 and 14 quarters, respectively. In response to a positive shock to portfolio debt inflow, US output goes up by 0.7 percentage points after 14 quarters. LPIRF and standard VAR impulse responses lead to similar results.

Finally, we compare local projection and standard VAR impulse responses to shocks to components of portfolio debt on US GDP in Figure 1-14. Panel A and Panel B exhibit impulse responses and accumulated impulse responses of US GDP to US government and corporate debt inflow shocks, respectively. A one standard deviation rise in US corporate debt inflow increases US GDP growth by 0.7 and 0.8 percentage points after two and five years, respectively. A positive shock to US government debt inflow elevates US output by 0.3 percentage points after two years. However, the effect turns negative after five years. Overall, local projection impulse responses support our claim that portfolio inflow shocks have positive and significant effects on the US economy.

\subsection{Results from Factor Augmented VAR Models}

One of the issues of the VAR approach is that every additional variable to the model increases the number of parameters that need to be estimated exponentially. Therefore, we have followed the conventional method by considering a core VAR and changing the variables to study their effects. Consequently, there might be concerns that our estimates are subjected to omitted variable bias. For example, if we included US interest rates, representing US monetary policy, would the effect of foreign investment on US GDP become negligible. In this section, we use two methods to study whether including the effects of US monetary policy influence our results. First, we use Factor Augmented VAR (FAVAR) method, similar to the framework used by Bernanke et al. (2005), to include the effects of US monetary policy. We assume that our core VAR variables 
are observable, so we can compare the impulse responses of our standard VAR and FAVAR models.

In all our FAVAR models, we assume US GDP is an observable, slow-moving factor, capital inflow variables are observable fast-moving factors and there is one unobservable fastmoving factor representing US monetary policy that is estimated from five US interest rate series. Observable factors are standardized versions of the associated observable variables and the unobservable factor is estimated using principal component method as explained by Bernanke et al. (2005).

Our FAVAR impulse responses are comparable to standard VAR impulse responses obtained from models (3) through (5). However, it is important to note that the vertical axes in our FAVAR impulse responses represent unit of standard deviation as all included factors are standardized. We only report impulse responses of US GDP to shocks to our variables of interest, portfolio inflow and its components. Therefore, to compare the FAVAR results with standard VAR ones we need to multiply the FAVAR responses by standard deviation of US GDP, 0.8 percentage points.

In the first FAVAR, we study the effect of portfolio inflow shocks on US GDP. The included factors are as follows:

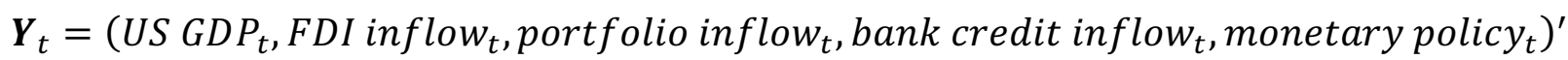

We assume that US GDP $P_{t}, F D I$ inflow $_{t}$, portfolio inflow, , bank credit inflow are $_{t}$ observable factors and monetary policy is $_{\text {in }}$ ubservable factor estimated using five US interest rate series. The interest rates are 3-Month Treasury Bill, 6-Month Treasury Bill, 1-Year Treasury Constant Maturity Rate, 2-Year Constant Maturity Rate, and 5-Year Constant Maturity Rate. 
To identify the shocks, we use recursive ordering and we assume that US GDP only responds to capital inflow and monetary policy innovations with a lag. We also assume that FDI does not respond to portfolio and bank credit inflow innovations within the same quarter. Similar to our standard VAR, portfolio and bank credit inflow respond to each other's innovations contemporaneously and in equal magnitudes. Following Bernanke et al. (2005) we order the monetary policy factor last so interest rate innovations that have not been captured by US GDP shocks, FDI shocks, portfolio inflow shocks and bank credit inflow shocks are defined as US monetary policy shocks.

Figure 1-15 shows that a positive shock to portfolio inflow has a positive and statistically significant effect on US GDP. A one standard deviation shock to portfolio inflow increases US output by 0.6 percentage points after two years, very close to 0.7 percentage points we found from our standard structural VAR model.

The second FAVAR studies the effect of shocks to components of portfolio inflow, equity and debt, on US output. The following factors are included:

$\boldsymbol{Y}_{t}=\left(U S G D P_{t}, \text { equity inflow }{ }_{t}, \text { debt inflow }{ }_{t}, \text { monetary policy }_{t}\right)^{\prime}$

We assume that US GDP only responds to equity, debt and monetary policy innovations with a lag. Equity and debt inflow respond to each other's innovations contemporaneously and in equal magnitudes. Interest rate innovations that have not been captured by US GDP, equity and debt shocks are defined by US monetary policy shocks.

Figure 1-16 illustrates the effect of equity and debt inflow shocks on US output. A positive one standard deviation shock to equity and debt inflow increase US GDP by equal magnitudes of 0.4 percentage points after two years. 
The final FAVAR displays the effect of US government debt and corporate debt inflow shocks on US GDP and contains the following factors:

$\boldsymbol{Y}_{t}=$

$\left(U S G_{D}, \text { US government debt inflow }{ }_{t}, \text { US corporate debt inflow }{ }_{t}, \text { monetary polic }_{t}\right)^{\prime}$

We assume that US output does not respond to US government, corporate debt inflow and monetary policy innovations contemporaneously. Moreover, US government debt inflow does not respond to US corporate debt inflow and monetary policy innovations within the same quarter. We also assume US corporate debt inflow innovations only respond to US monetary policy shocks with a lag. Interest rate innovations that cannot be explained by US GDP shocks, US government and corporate debt inflow shocks are captured by US monetary policy shocks.

Figure 1-17 shows a positive shock to US corporate debt inflow has a positive and statistically significant effect on US output. A one standard deviation shock to US corporate debt increases US GDP by 0.6 percentage points after eight quarters. A positive shock to US government debt inflow has a small positive but statistically insignificant long-term effect on US output.

In the second method, we include the $\mathrm{Wu}$-Xia shadow federal funds rate in our standard VAR models to study the effects of US monetary policy on our estimates. Effective Federal Funds rate remained below 25 basis points for almost seven years, so we include $\mathrm{Wu}-\mathrm{Xia}$ shadow federal funds rate instead of Effective Federal Funds Rate to capture Federal Reserve unconventional monetary policy during and after the financial crisis. This data adds valuable information that might not be represented fully by Effective Federal Funds rate alone. Wu and Xia (2016) estimated shadow federal funds rate and allowed it to become negative.

Black (1995) explained that the short-term interest rate cannot be negative because we have currency with zero interest rate as an option. If currency was not an option, then interest rate could 
become negative and shadow interest rate captures that. Wu and Xia (2016)'s shadow federal funds rate is identical to Effective Federal Funds rate when the shadow fed funds rate is at least 25 basis points. However, they deviate when the rate ranges between 0 and 25 basis points. The results are similar to standard VAR impulse responses. ${ }^{10}$

Our conclusion that portfolio inflow shocks have a positive and significant impact on US economy holds even when we account for US monetary policy.

\subsection{Conclusion}

The aim of this chapter is to estimate the effect of portfolio inflow and its components on the US economy. While there is a wide range of papers covering multiple aspects of capital flows to and from emerging economies, there are not many papers that study the effects of foreign investments on output in advanced economies. This chapter addresses that issue by focusing on the United States. We use structural VAR methods because it allows us to incorporate feedback effects in our models. We use rest of the world section of US financial accounts, a dataset from 1980 Q1 to 2016 Q1, which is available from Board of Governors of the Federal Reserve System's website. This disaggregated database allows us to study the impact of shocks to components of portfolio inflow on US GDP.

Our results show that a one standard deviation shock to foreign portfolio investment increases US GDP growth by 0.7 percentage points after two years. We also find that a positive shock to US corporate debt inflow has a positive and significant effect on US GDP growth in the long run. A one standard deviation shock to US corporate debt inflow improves US output growth by 0.7 percentage points within two years. Our results suggest that while the effect of equity inflow

\footnotetext{
10 The results are not reported in the chapter, but they are available upon request.
} 
on the US economy is similar to what has been reported for emerging economies, the effect of debt inflow on US GDP is significantly greater than what has been found for developing economies. For example, Blanchard et al. (2015) estimated that one percent increases of portfolio equity inflow and debt inflow increase emerging economies GDP growth by 0.5 and 0.03 percentage points, respectively.

Our results are robust to using local projection methods to estimate impulse responses. Local projection impulse responses are robust to misspecification and provide reliable results for longer horizons. Furthermore, the effect of portfolio inflow shocks on US GDP remains positive and significant even after we control for the effects of US monetary policy. Our findings can be particularly beneficial to policy makers in emerging countries and provide a further motive for them to encourage the development of their capital markets. By studying the impact of capital inflows on the US economy, emerging economies can project the effect of foreign investment on their own growth once their financial markets are fully developed. 


\subsection{References}

Aizenman, J., Chinn, M. D., \& Ito, H. (2010). The emerging global financial architecture: Tracing and evaluating new patterns of the trilemma configuration. Journal of International Money and Finance, 29(4), 615-641.

Aizenman, J., Jinjarak, Y., \& Park, D. (2013). Capital Flows and Economic Growth in the Era of Financial Integration and Crisis, 1990-2010. Open Economies Review, 24(3), 371-396.

Backus, D., Henriksen, E., Lambert, F., \& Telmer, C. (2009). Current Account Fact and Fiction. NBER Working Paper No. 15525.

Bernanke, B. S., Boivin, J., \& Eliasz, P. (2005). Measuring the Effects of Monetary Policy: A Factor-Augmented Vector Autoregressive (FAVAR) Approach. The Quarterly Journal of Economics, 120(1), 387-422.

Black, F. (1995). Interest Rates as Options. The Journal of Finance, 50(5), 1371-1376.

Blanchard, O., Ostry, J. D., Ghosh, A. R., \& Chamon, M. (2015). Are Capital Inflows Expansionary or Contractionary? Theory, Policy Implications, and Some Evidence. NBER Working Paper No. 21619.

Blanchard, O., Ostry, J. D., Ghosh, A. R., \& Chamon, M. (2016). Capital Flows: Expansionary or Contractionary? American Economic Review: Papers and Proceedings, 565-569.

Board of Governors of the Federal Reserve System. (2017, December 7). Financial Accounts of the United States - Z.1. Retrieved from Board of Governors of the Federal Reserve System: https://www.federalreserve.gov/releases/z1/current/html/introductory_text.htm 
Bosworth, B. P., \& Collins, S. M. (1999). Capital Flows to Developing Economies: Implications for Saving and Investment. Brookings Papers on Economic Activity, 1999(1), 143-180.

Broner, F., Didier, T., Erce, A., \& Schmukler, S. L. (2013). Gross capital flows: Dynamics and crises. Journal of Monetary Economics, 60(1), 113-133.

De la Torre, A., Didier, T., \& Pienknagura, S. (2012). Latin America Copes with Volatility: The Dark Side of Globalization. World Bank Latin America and Caribbean Semi-Annual Report.

De Vita, G., \& Kyaw, K. S. (2008). Determinants of Capital Flows to Developing Countries: a Structural VAR Analysis. Journal of Economic Studies, 35(4), 304-322.

Durham, J. B. (2003, February). Foreign Portfolio Investment, Foreign Bank Lending, and Economic Growth. Board of Governors of the Federal Reserve System International Finance Discussion Papers No.757.

Evans, M. D. (2017). External balances, trade and financial conditions. Journal of International Economics, 107, 165-184.

Ferreira, M. A., \& Laux, P. A. (2009). Portfolio flows, volatility and growth. Journal of International Money and Finance(28), 271-292.

Forbes, K. J., \& Warnock, F. E. (2012). Capital flow waves: Surges, stops, flight, and retrenchment. Journal of International Economics, 88(2), 235-251.

Haque, S. M., Huang, Z., \& Kunii, K. (2015). External Solvency Analysis: Can US sustain its debt? Retrieved from SSRN: https://ssrn.com/abstract=2777833 or http://dx.doi.org/10.2139/ssrn.2777833 
Higgins, M., \& Klitgaard, T. (1998). Viewing the US Current Account Deficit as a Capital Inflow. Current Issues in Economics and Finance, 4(13).

Iwasaki, I., \& Tokunaga, M. (2014). Macroeconomic Impacts of FDI in Transition Economies: A Meta-Analysis. World Development, 61, 53-69.

Jordà, Ò. (2005). Estimation and Inference of Impulse Responses by Local Projections. American Economic Review(95), 161-182.

Kilian, L. (2001). Impulse Response Analysis in Vector Autoregressions with Unknown Lag Order. Journal of Forecasting(20), 161-179.

Kilian, L., \& Kim, Y. (2011). How Reliable Are Local Projection Estimators of Impulse Responses? Review of Economics and Statistics, 93(4), 1460-1466.

Magud, N. E., Reinhart, C., \& Rogoff, K. (2011). Capital Controls: Myth and Reality - A Portfolio Balance Approach. NBER Working Papers 16805.

Obstfeld, M. (2012). Does the Current Account Still Matter? American Economic Review, 102(3), 1-23.

Obstfeld, M., \& Rogoff, K. (2007). The Usustainable US Current Account Position Revisited. In R. H. Clarida, G7 Current Account Imbalances: Sustainability and Adjustment (pp. 339376). University of Chicago Press.

Prasad, E. S., Rajan, R. G., \& Subramanian, A. (2007). Foreign Capital and Economic Growth. Brookings Papers on Economic Activity, 1, 153-230.

Ramey, V. A. (2016). Macroeconomic Shocks and Their Propagation. NBER Working Paper 21978. 
Ronayne, D. (2011). Which Impulse Response Function? Warwick economic research papers, no 971. University of Warwick, Department of Economics.

Sims, C. A. (1980). Macroeconomics and Reality. Econometrica, 48(1), 1-48.

Summers, L. H. (2004, March 23). The United States and the Global Adjustment Process. Speach at the Third Annual Stavros S. Niarchos Lecture Institute for International Economics. Washington DC: Peterson Institute for International Economics.

Warnock, F. E., \& Warnock, V. C. (2009). International capital flows and US interest rates. Journal of International Money and Finance, 28, 903-919.

Wu, J., \& Xia, F. (2016). Measuring the Macroeconomic Impact of Monetary Policy at the Zero Lower Bound. Journal of Money, Credit and Banking, 48(2-3), 253-291. 
Table 1-1-Description of capital inflow variables

\begin{tabular}{|l|l|}
\hline Capital flow Variables & \multicolumn{1}{c|}{ Brief description } \\
\hline net capital inflow & $\begin{array}{l}\text { The difference between total US assets held by foreigners and total foreign assets held by US } \\
\text { residents }\end{array}$ \\
\hline Gross capital inflow & Total US assets held by foreigners which include FDI in the US, portfolio and bank credit inflows \\
\hline Gross capital outflow & $\begin{array}{l}\text { Total foreign assets held by US residents which include FDI abroad, portfolio and bank credit } \\
\text { outflows }\end{array}$ \\
\hline FDI inflow (current cost) & $\begin{array}{l}\text { US equity and debt held by foreigners when they own and control 10 percent or more of nonresident } \\
\text { entity's voting securities. It is calculated based on the cost of FDI assets at the time of their purchase }\end{array}$ \\
\hline FDI inflow (market value) & $\begin{array}{l}\text { US equity and debt held by foreigners when they own and control 10 percent or more of nonresident } \\
\text { entity's voting securities. It is calculated based on the market value of FDI assets at that point in time }\end{array}$ \\
\hline Portfolio inflow & US equity and debt held by foreigners that are not included in FDI \\
\hline Bank credit inflow & Financial assets held by foreigners that are not included in FDI and portfolio investments \\
\hline Portfolio equity inflow & US corporate equity, mutual fund shares and money market shares held by foreigners \\
\hline Portfolio debt inflow & US corporate debts and US government debts held by foreigners \\
\hline US corporate debt inflow & US corporate bonds and open market paper also known as commercial paper held by foreigners \\
\hline US government debt inflow & US Treasury and municipal securities and Agency and GSE-backed securities held by foreigners \\
\hline
\end{tabular}


Table 1-2-Descriptive Statistics of the variables

\begin{tabular}{|c|c|c|c|c|c|c|c|}
\hline Variables & Mean & Maximum & Minimum & Std. Dev. & Source & Sample & \# Obs. \\
\hline Real GDP growth & 0.52 & 2.04 & -3.20 & 0.79 & $\mathrm{BEA}^{1}$ & 1980 Q1-2016Q1 & 145 \\
\hline Real GDP growth & 2.13 & 6.22 & -4.27 & 2.13 & $\mathrm{BEA}^{1}$ & $1976-2016^{6}$ & 40 \\
\hline Real net capital inflow growth & 9.12 & 574.49 & -576.61 & 77.60 & $\mathrm{FRB}^{2}$ & 1980 Q1-2016Q1 & 145 \\
\hline Real total capital inflow growth & 1.99 & 13.43 & -4.67 & 2.49 & $\mathrm{FRB}^{2}$ & 1980 Q1-2016Q1 & 145 \\
\hline Real total capital outflow growth & 1.55 & 13.37 & -11.61 & 3.50 & $\mathrm{FRB}^{2}$ & 1980 Q1-2016Q1 & 145 \\
\hline Real FDI inflow growth (current cost) & 1.78 & 18.88 & -5.02 & 2.75 & $\mathrm{FRB}^{2}$ & 1980 Q1-2016Q1 & 145 \\
\hline Real FDI inflow growth (market value) & 9.21 & 54.34 & -32.82 & 14.54 & $\mathrm{BEA}^{3}$ & $1976-2016^{6}$ & 40 \\
\hline Real portfolio inflow growth & 2.26 & 11.65 & -9.25 & 3.39 & $\mathrm{FRB}^{2}$ & 1980 Q1-2016Q1 & 145 \\
\hline Real portfolio inflow growth & 8.23 & 24.43 & -14.50 & 8.53 & $\mathrm{BEA}^{3}$ & $1976-2016^{6}$ & 40 \\
\hline Real bank credit inflow growth & 1.35 & 33.26 & -23.68 & 7.04 & $\mathrm{FRB}^{2}$ & 1980 Q1-2016Q1 & 145 \\
\hline Real bank credit inflow growth & 6.40 & 23.63 & -8.21 & 7.83 & $\mathrm{BEA}^{3}$ & $1976-2016^{6}$ & 40 \\
\hline Real portfolio equity inflow growth & 2.46 & 20.84 & -32.59 & 8.37 & $\mathrm{FRB}^{2}$ & 1980 Q1-2016Q1 & 145 \\
\hline Real portfolio debt inflow growth & 2.17 & 10.88 & -6.33 & 2.58 & $\mathrm{FRB}^{2}$ & 1980 Q1-2016Q1 & 145 \\
\hline Real US corporate debt inflow growth & 2.61 & 21.68 & -13.75 & 4.30 & $\mathrm{FRB}^{2}$ & 1980 Q1-2016Q1 & 145 \\
\hline Real US government debt inflow growth & 2.04 & 12.98 & -7.57 & 2.97 & $\mathrm{FRB}^{2}$ & 1980 Q1-2016Q1 & 145 \\
\hline 3-Month Treasury Bill Rate & 4.53 & 15.05 & 0.01 & 3.60 & FRED $^{4}$ & 1980 Q1-2016Q1 & 145 \\
\hline 6-Month Treasury Bill Rate & 4.63 & 15.06 & 0.05 & 3.58 & FRED $^{4}$ & 1980 Q1-2016Q1 & 145 \\
\hline 1-Year Treasury Constant Maturity Rate & 5.03 & 16.32 & 0.10 & 3.84 & FRED $^{4}$ & 1980 Q1-2016Q1 & 145 \\
\hline 2-Year Treasury Constant Maturity Rate & 5.38 & 16.03 & 0.26 & 3.82 & FRED $^{4}$ & 1980 Q1-2016Q1 & 145 \\
\hline 5- Year Treasury Constant Maturity Rate & 5.94 & 15.43 & 0.67 & 3.54 & FRED $^{4}$ & 1980 Q1-2016Q1 & 145 \\
\hline Wu-Xia shadow federal funds rate & 4.92 & 18.37 & -2.92 & 4.56 & FRBA $^{5}$ & 1980 Q1-2016Q1 & 145 \\
\hline
\end{tabular}

${ }^{1}$ National Data from US Bureau of Economic Analysis

${ }^{2}$ Financial Accounts of the United States from Board of Governors of the Federal Reserve System

${ }^{3}$ International Investment Position from US Bureau of Economic Analysis

${ }^{4}$ Federal Reserve Bank of St. Louis

${ }^{5} \mathrm{Wu}$-Xia Shadow Federal Funds Rate from Federal Reserve Bank of Atlanta

${ }^{6}$ Annual data 
Figure 1-1-US international investments

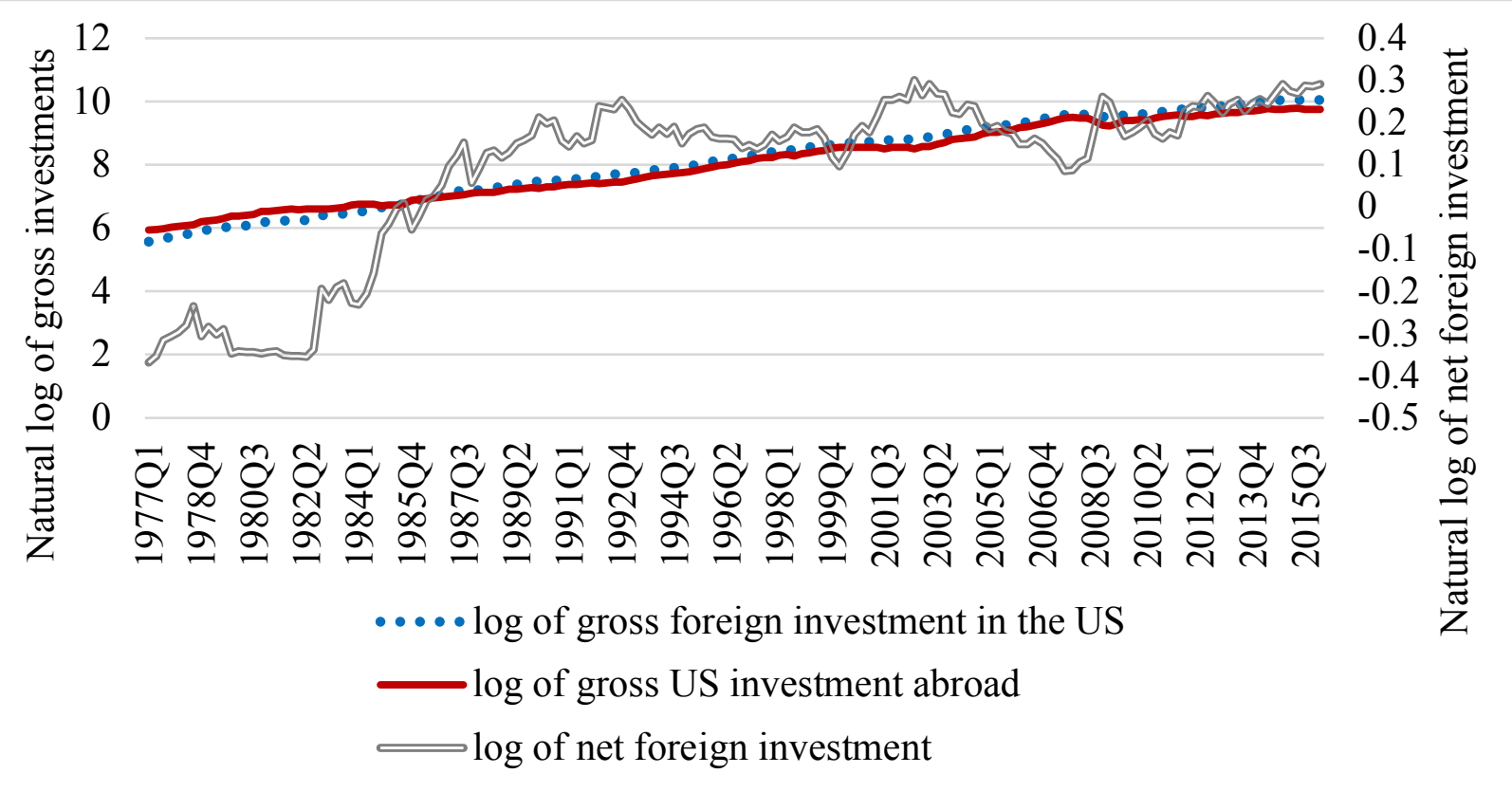

Source: Financial Accounts of the United States, Board of Governors of the Federal Reserve System 
Figure 1-2-Main components of total foreign investment in the US

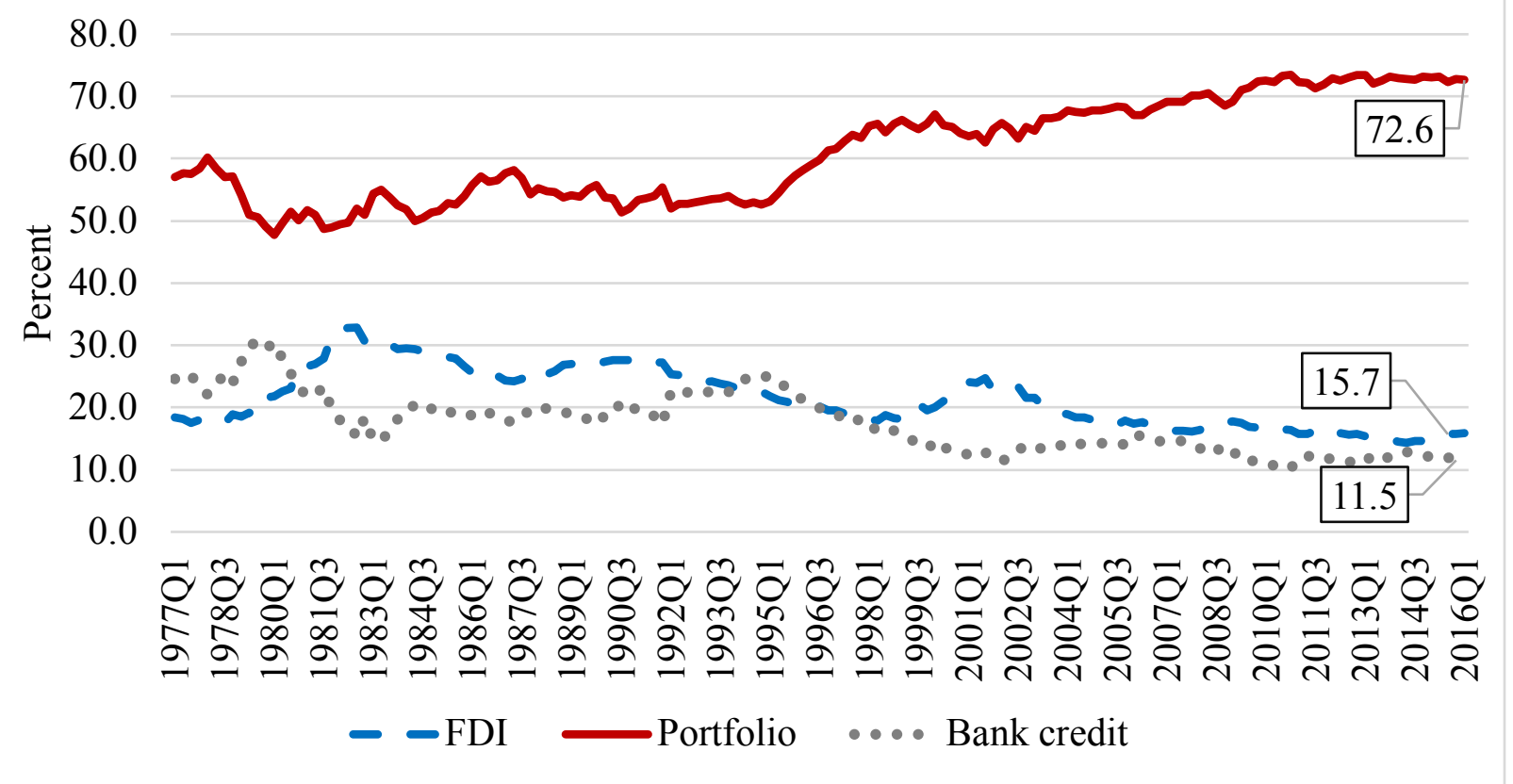

Source: Financial Accounts of the United States, Board of Governors of the Federal Reserve System 
Figure 1-3-Change in composition of foreign investment in the US

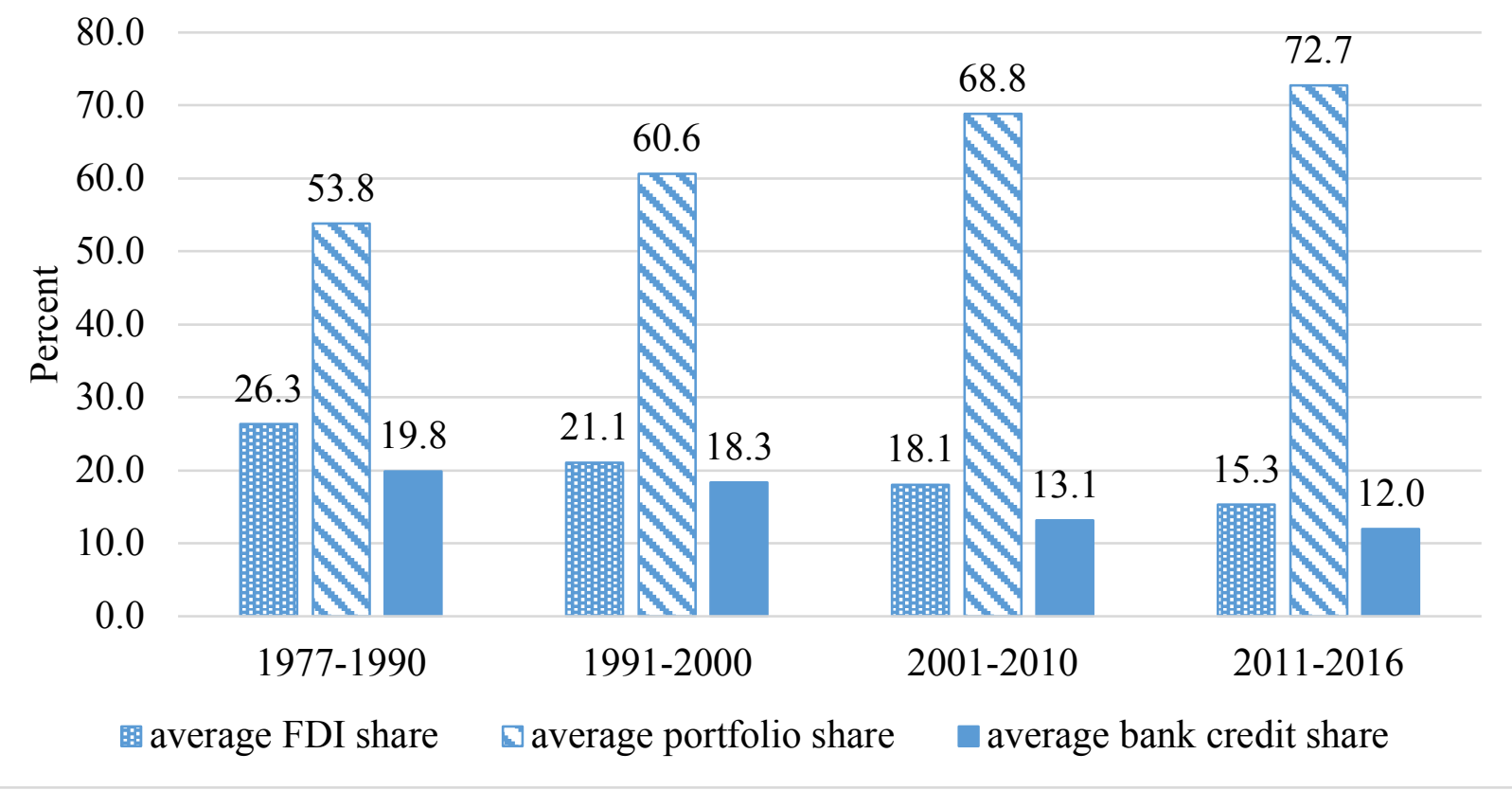

Source: Financial Accounts of the United States, Board of Governors of the Federal Reserve System 
Figure 1-4-Debt and equity as share of portfolio investment

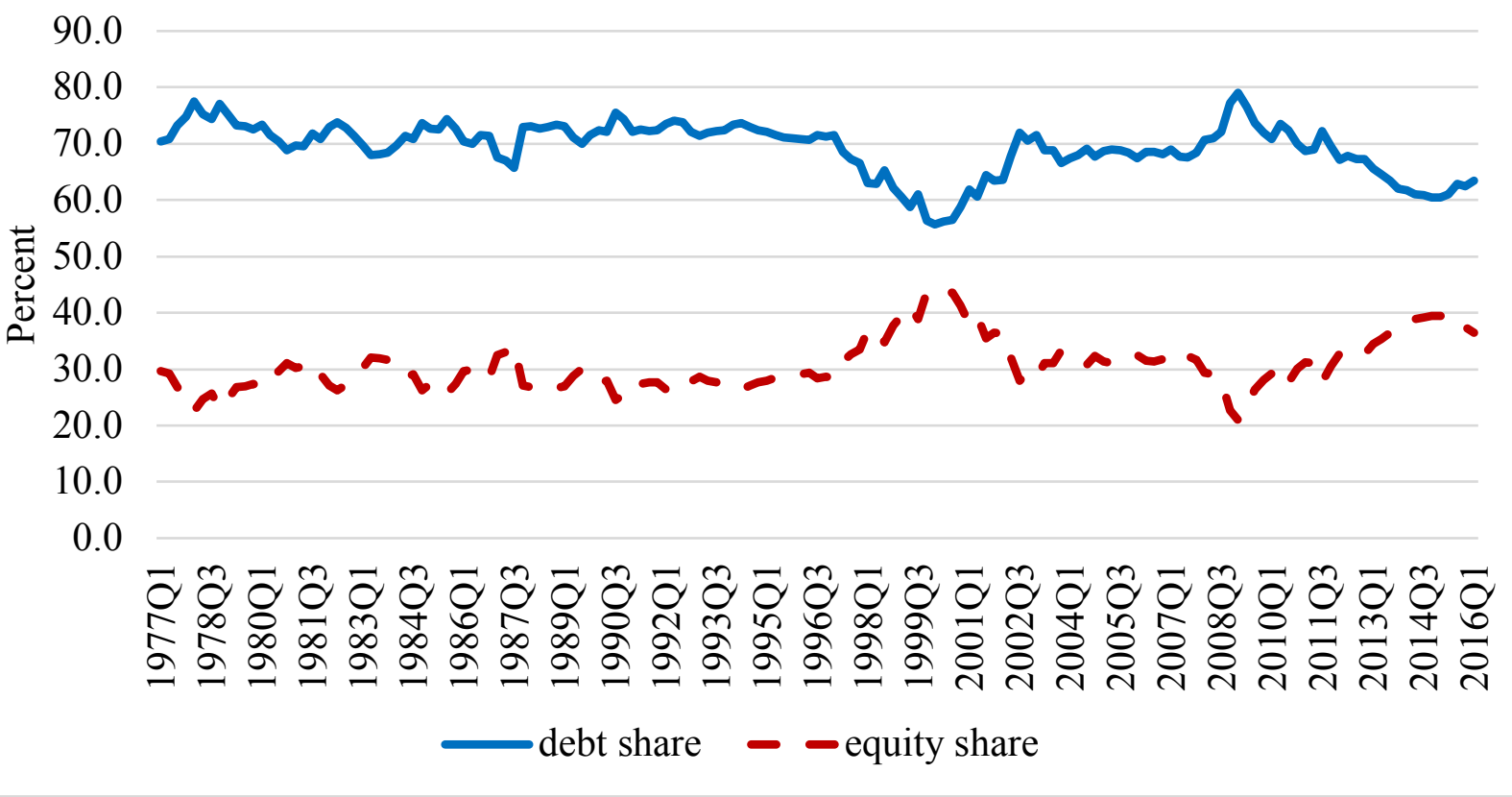

Source: Financial Accounts of the United States, Board of Governors of the Federal Reserve System 
Figure 1-5-Impulse responses for US GDP and net foreign investments

Accumulated Response to Structural One S.D. Innovations \pm 2 S.E.

Response of US GDP to US GDP shock

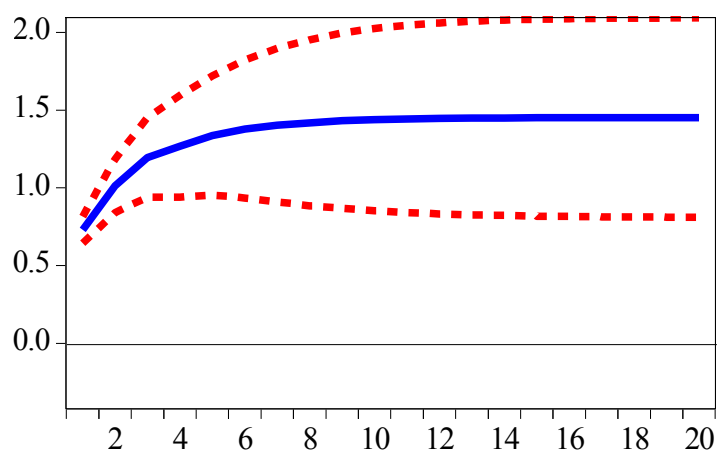

Response of net capital inflow to US GDP shock

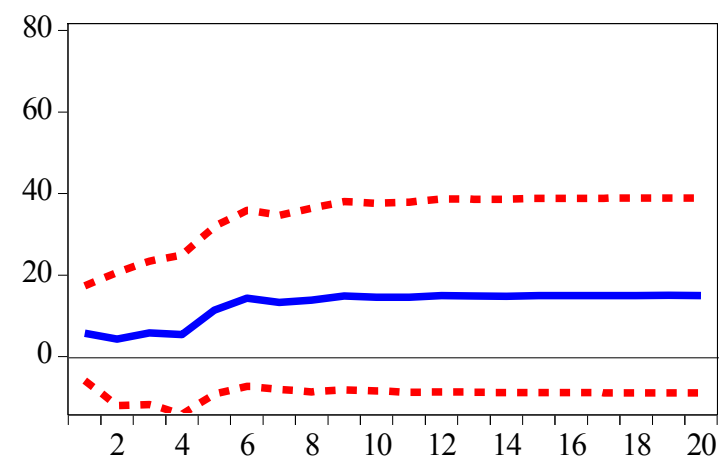

Response of US GDP to net capital inflow shock

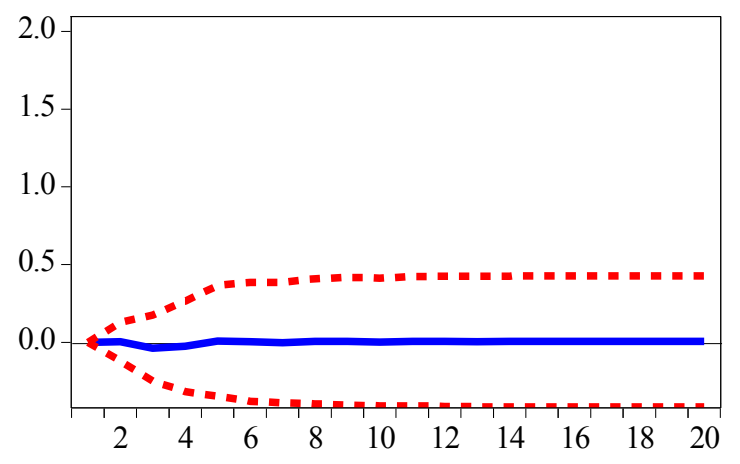

Response of net capital inflow to net capital inflow shock

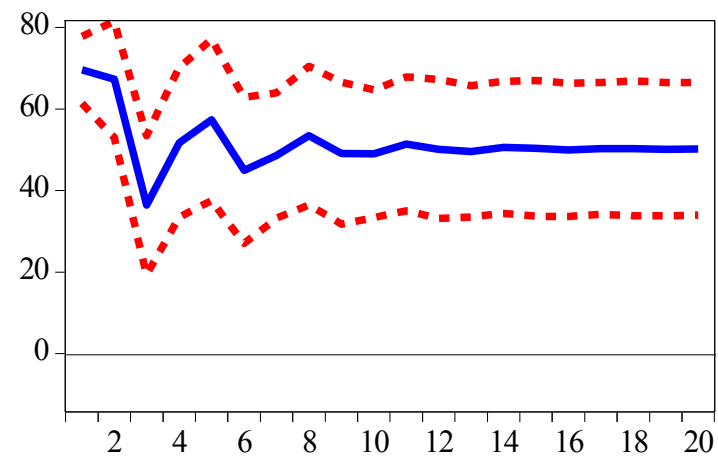




\section{Figure 1-6-Impulse responses for US GDP, capital inflow and capital outflow}

\section{Accumulated Response to Structural One S.D. Innovations \pm 2 S.E.}

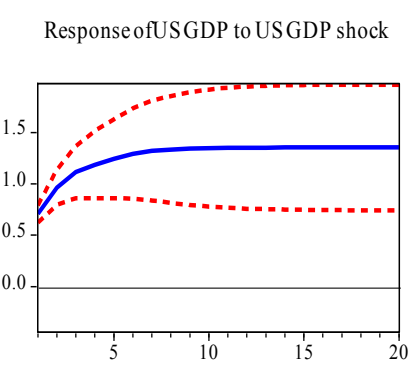

Response ofgross capital inflow to USGDP shock

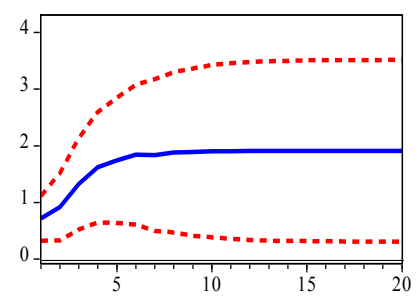

Response ofgross capital outflow to US GDP shock

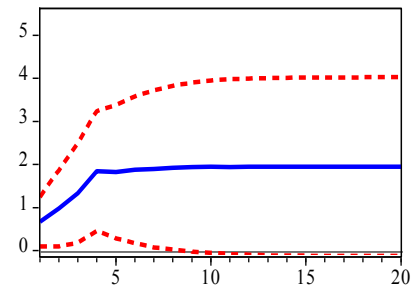

Response ofUS GDP to gross capital inflow shock

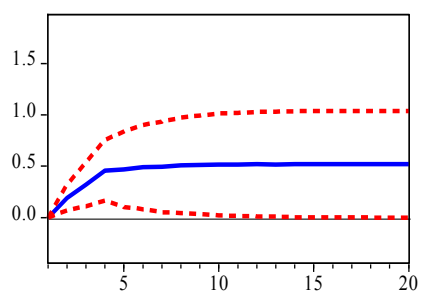

Response ofgross capital inflow to gross capital inflow shock

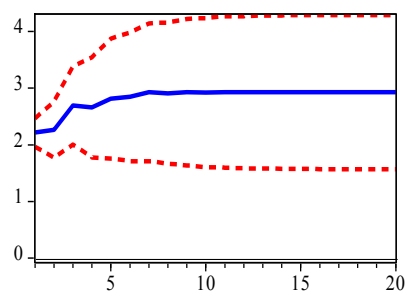

Response ofgross capital outflow to gross capital inflow shock

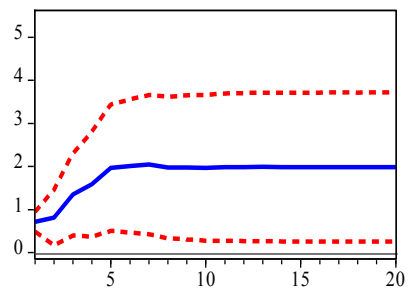

Response ofUS GDP to gross capital outflow shock

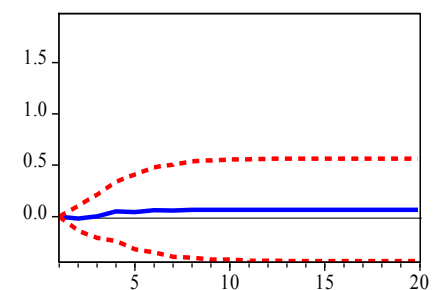

Response ofgross capital inflow to gross capital outflow shock

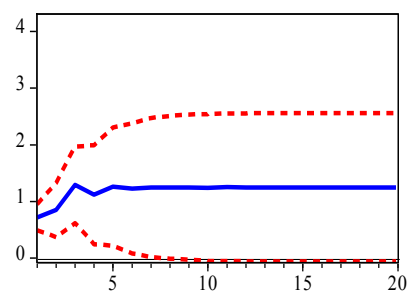

Response ofgross capital outflow to gross capital outflow shock

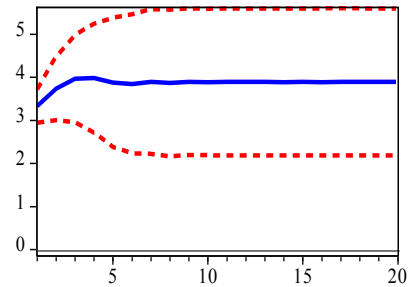


Figure 1-7-Impulse responses for US GDP, FDI, portfolio inflow and bank credits Accumulated Response to Structural One S.D. Innovations \pm 2 S.E.

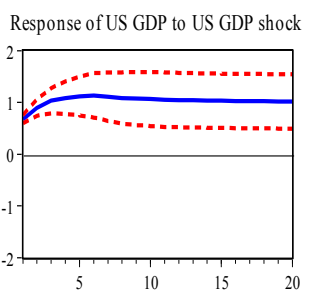

Response of FDI inflow to US GDP shock

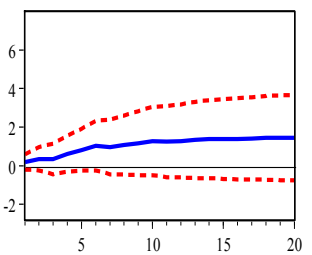

Response of portfolio inflow to US GDP shock

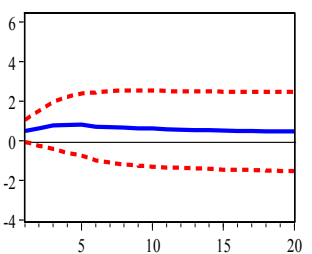

Response of bank credit inflow to US GDP shock

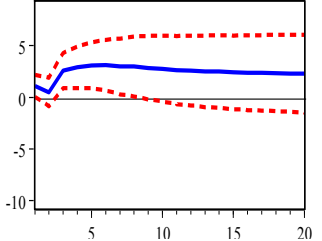

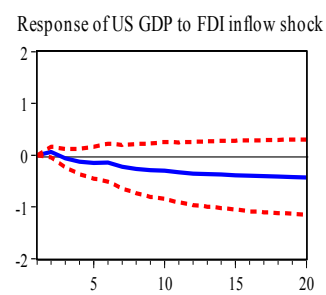

Response ofFDI inflow to FDI inflow shock

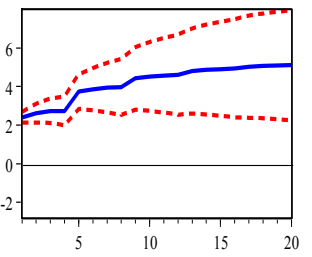

Response of portfolio inflow to FDI inflow shock

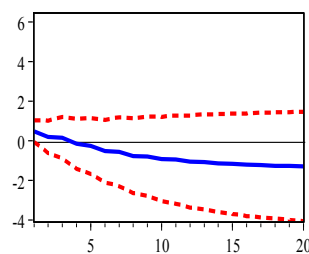

Response of bank credit inflow to FDI inflow shock Response of bank credit inflow to portfolio inflow shock

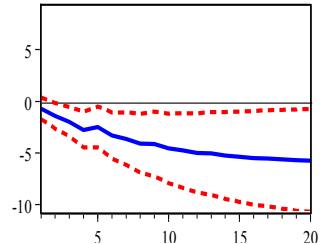

Response of US GDP to portfolio inflow shock

Response of FDI inflow to portfolio inflow shock

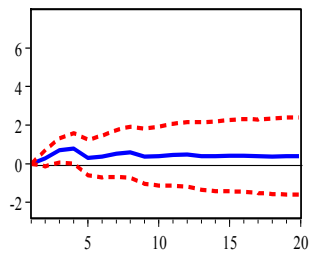

Response of portfolio inflow to portfolio inflow shock
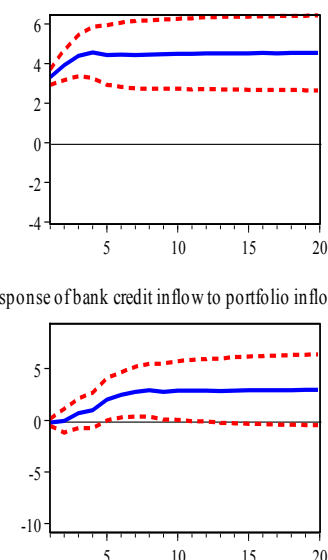

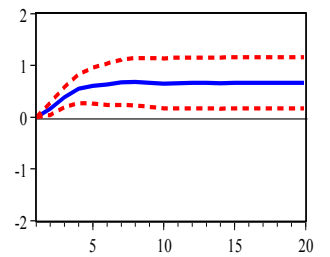

Response of US GDP to bank credit inflow shock

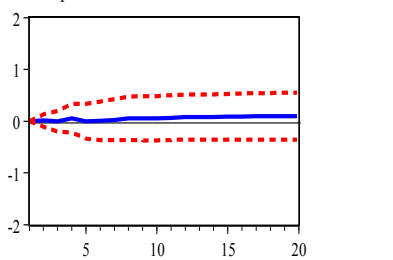

Response of FDI inflow to bank credit inflow shock

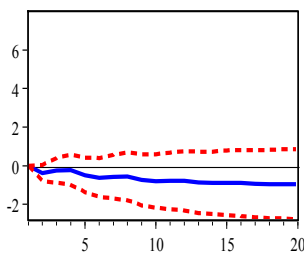

Response of portfolio inflow to bank credit inflow shock

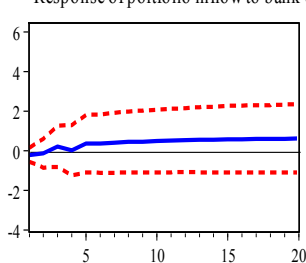

Response of bank credit inflow to bank credit inflow shock

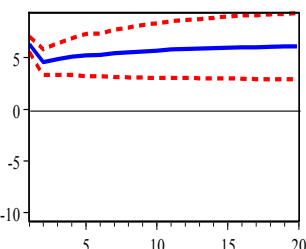


Figure 1-8-FDI current cost and market value

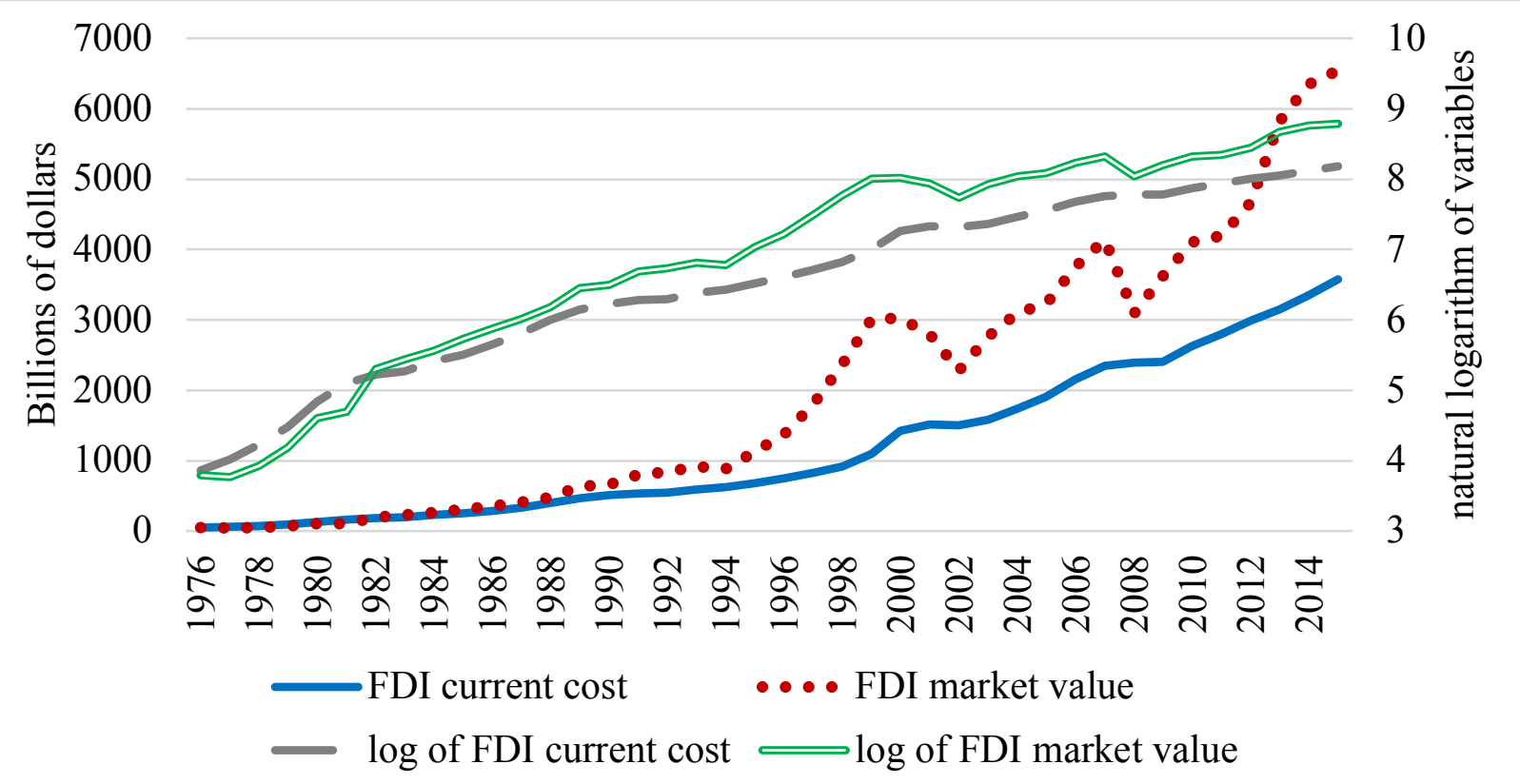

Source: Financial Accounts of the United States, Board of Governors of the Federal Reserve System and International Investment Position, US Bureau of Economic Analysis 
Figure 1-9-Impulse responses for US GDP, FDI, portfolio inflow and bank credits Accumulated Response to Structural One S.D. Innovations \pm 2 S.E.

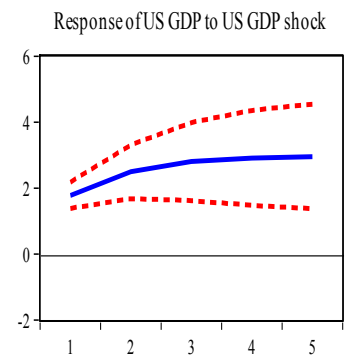

Accumulated Response to Structural One S.D. Innovations \pm 2 S.E.

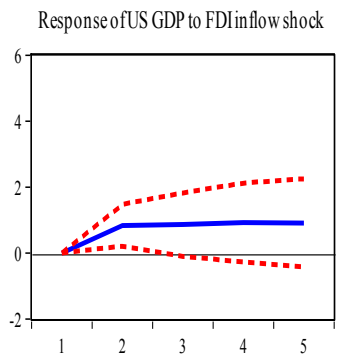

Response ofUS GDP to portfolio inflow shock
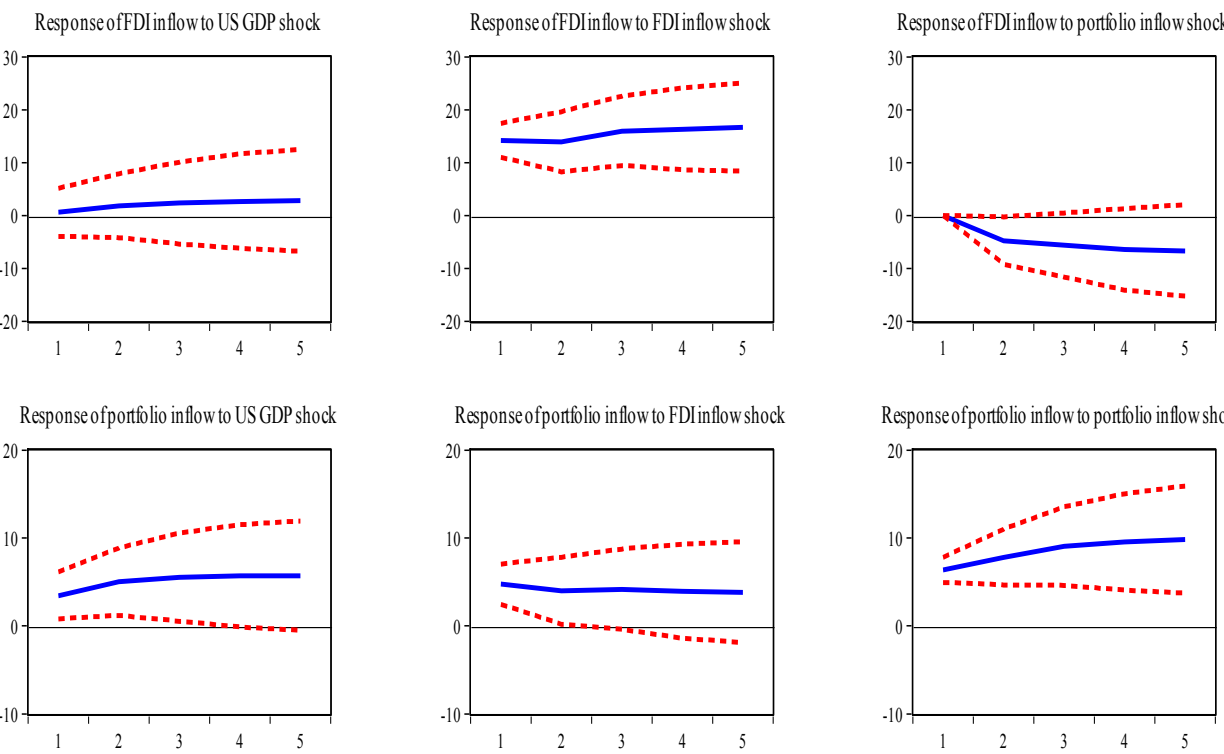

Response ofportfolio inflow to FDlinflow shock

Response of portfolio inflow to portfolio inflow shock
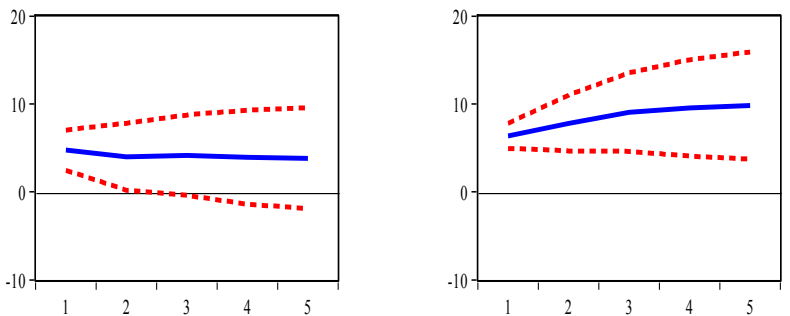

Response ofbank credit inflow to US GDP shock

Response ofbank credit inflow to FDlinflow shock

Response ofbank credit inflow to portfolio inflow shock
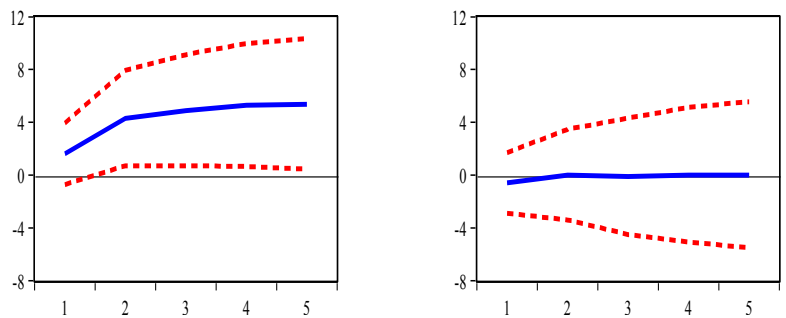

Response ofUS GDP to bank credit inflow shock

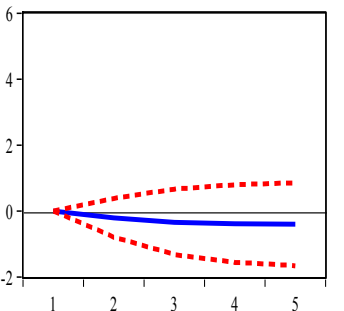

Response ofFDI inflow to bank credit inflow shock

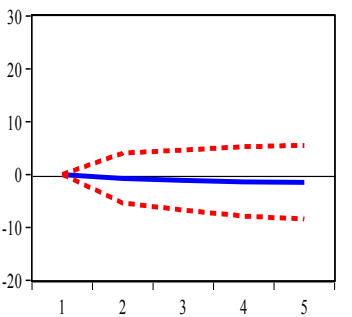

Response of portfolio inflow to bank credit inflow shock

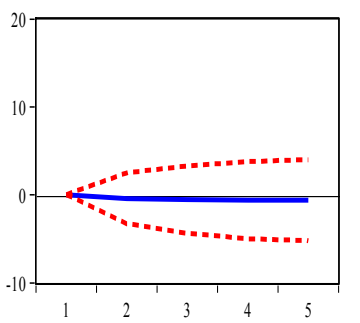

Response ofbank credit inflow to bank credit inflow shock

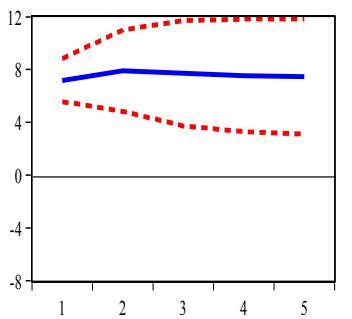




\section{Figure 1-10-Impulse responses for US GDP, equity and debt inflow}

Accumulated Response to Structural One S.D. Innovations \pm 2 S.E.

Response of US GDP to US GDP shock

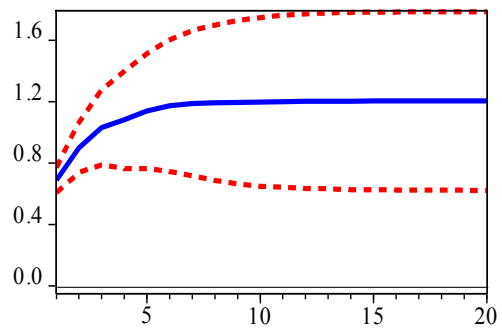

Response of equity inflow to US GDP shock

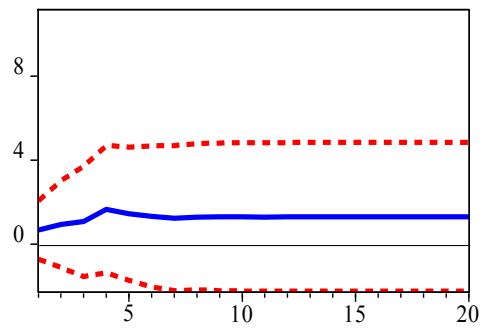

Response of debt inflow to US GDP shock

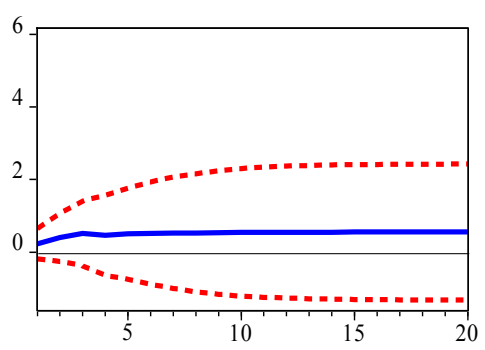

Response of US GDP to equity inflow shock

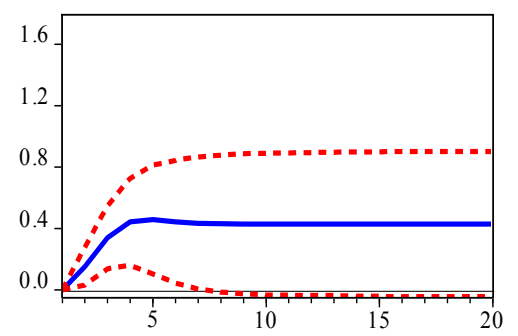

Response of equity inflow to equity inflow shock

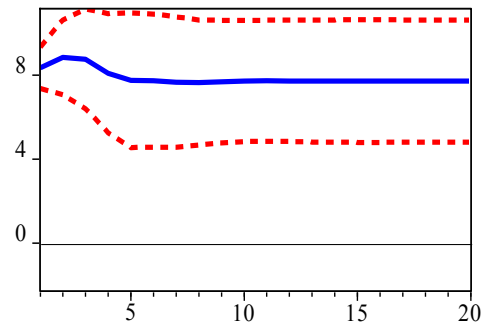

Response of debt inflow to equity inflow shock

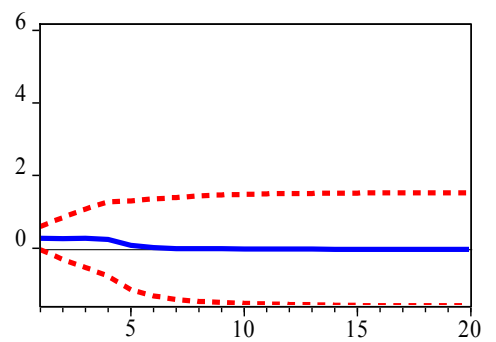

Response of US GDP to debt inflow shock

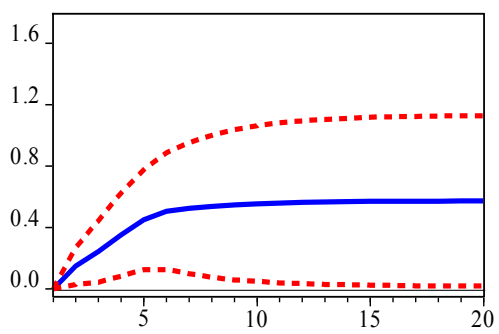

Response of equity inflow to debt inflow shock

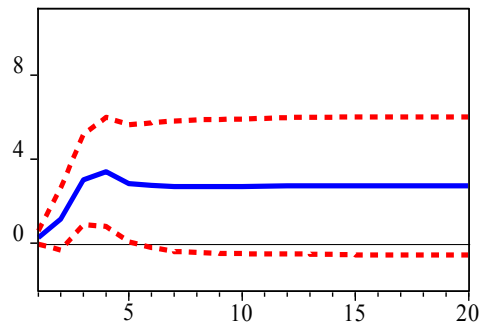

Response of debt inflow to debt inflow shock

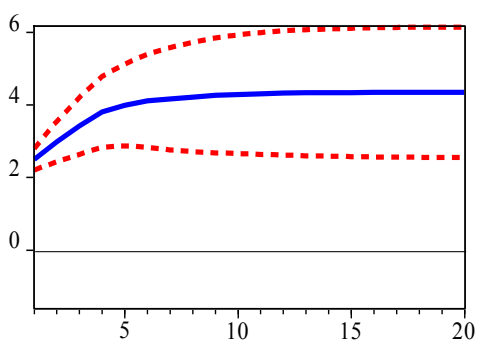


Figure 1-11-Impulse responses for US GDP, government debt and corporate debt Accumulated Response to Structural One S.D. Innovations \pm 2 S.E.

Response of US GDP to US GDP shock

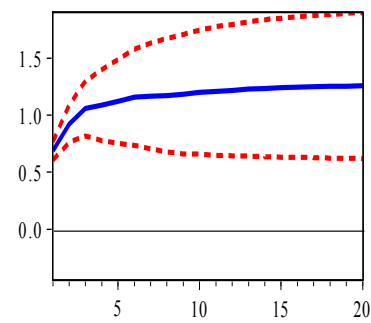

Response of US govemment debt inflow to US GDP shock

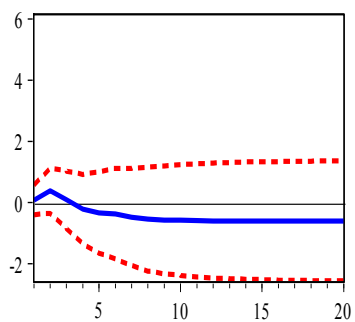

Response of US corporate debt inflow to US GDP shock

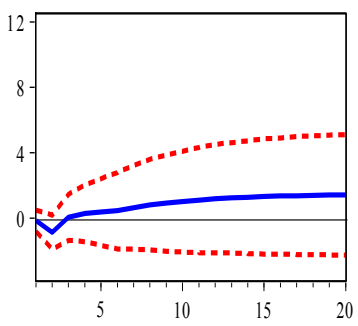

Response of US GDP to US govemment debt inflow shock

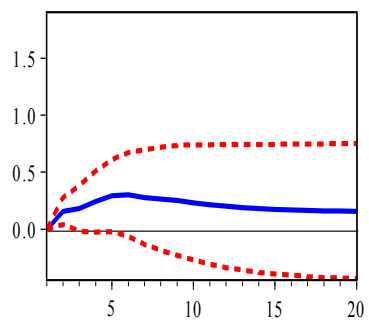

Response of US government debt inflow to US govemment debt inflow shock

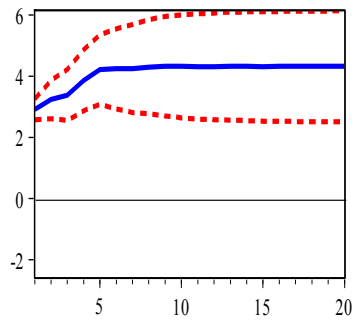

Response of US corporate debt inflow to US govemment debt inflow shock

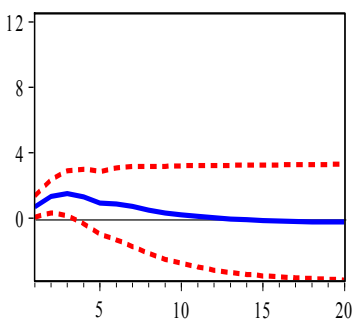

Response of US GDP to US comprate debt inflow shock

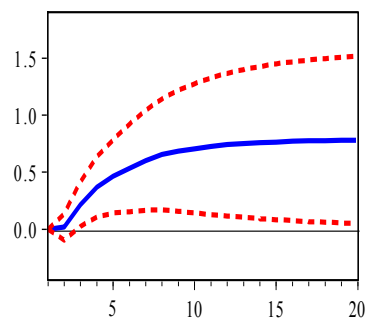

Response of US govemment debt inflow to US corporate debt inflow shock

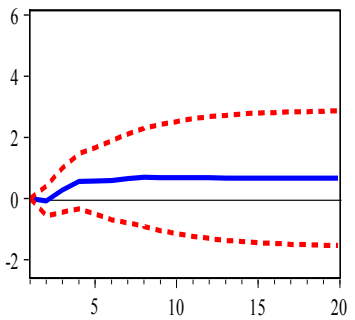

Response of US corporate debt inflow to US corporate debt inflow shock

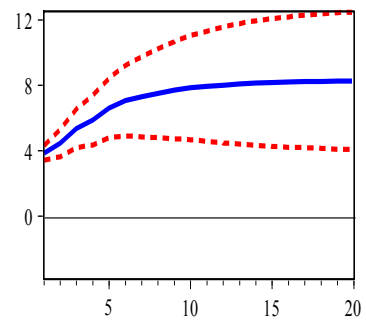


Figure 1-12-LP impulse responses for US GDP and portfolio inflow

Panel A: Responses to structural one S.D. innovations

Response of US GDP to portfolio inflow

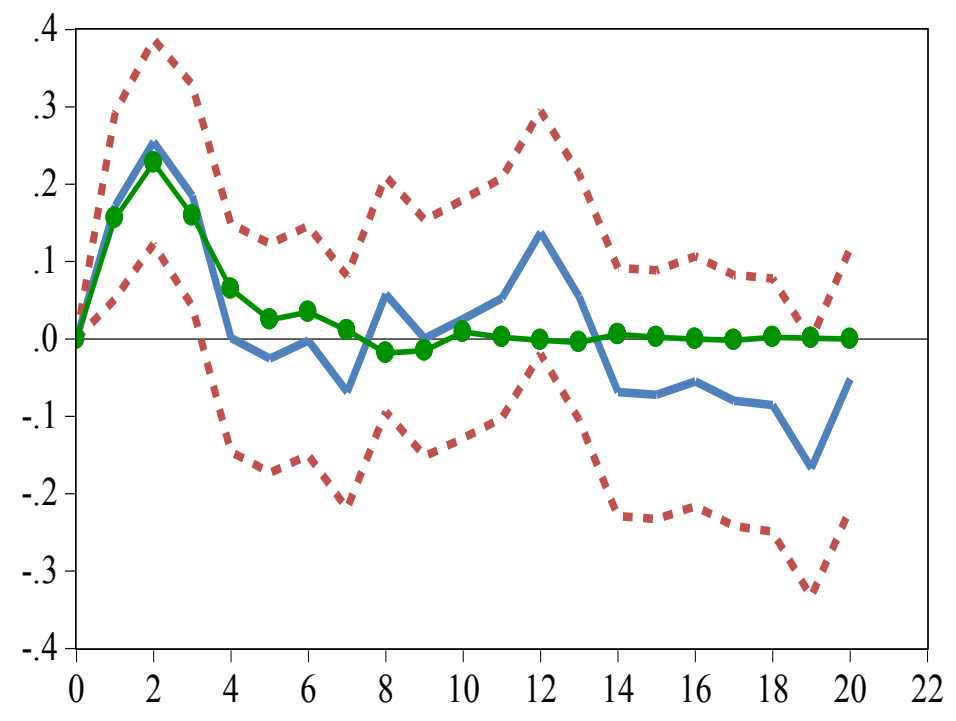

Note: The blue solid line is the impulse responses calculated by local projections method, red dash lines are two standard error bands for coefficients of local projections responses and the green line with circles is the impulse response from the standard VAR model.

Panel B: Accumulated responses to structural one S.D. innovations

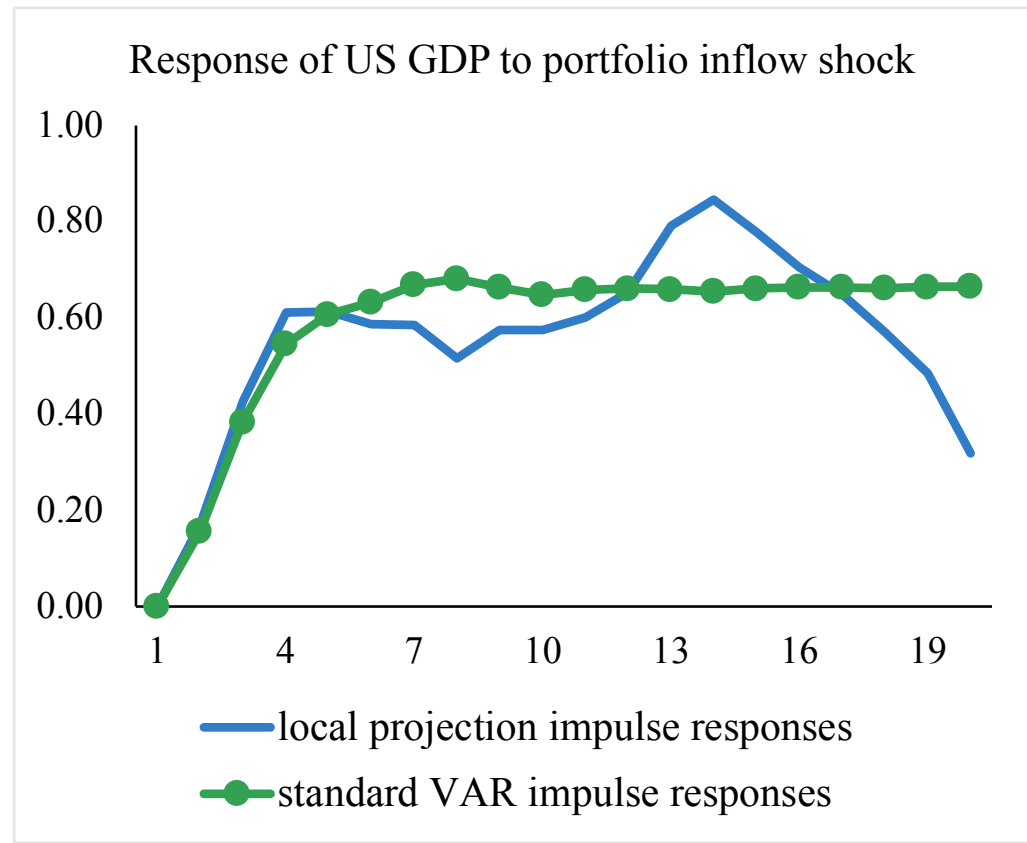


Figure 1-13-LP impulse responses for US GDP, equity and debt inflow

Panel A: Responses to structural one S.D. innovations
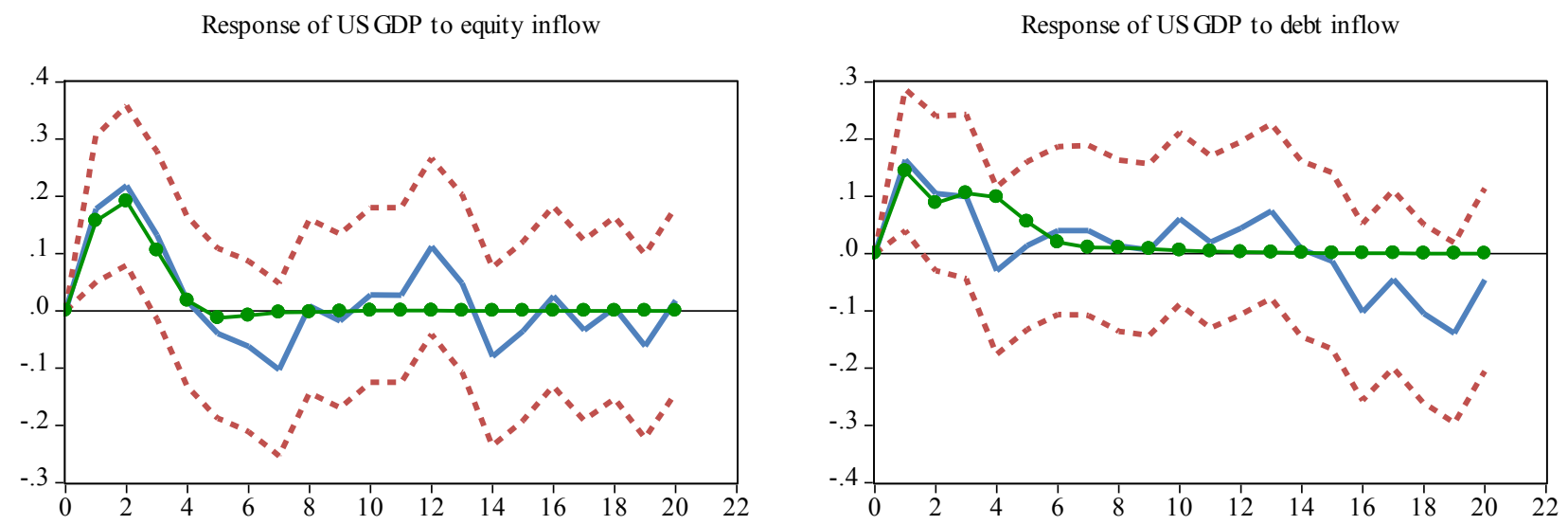

Note: The blue solid lines are the impulse responses calculated by local projections method, red dash lines are two standard error bands for coefficients of local projections responses and the green lines with circles are the impulse response from standard VAR models.

Panel B: Accumulated responses to structural one S.D. innovations
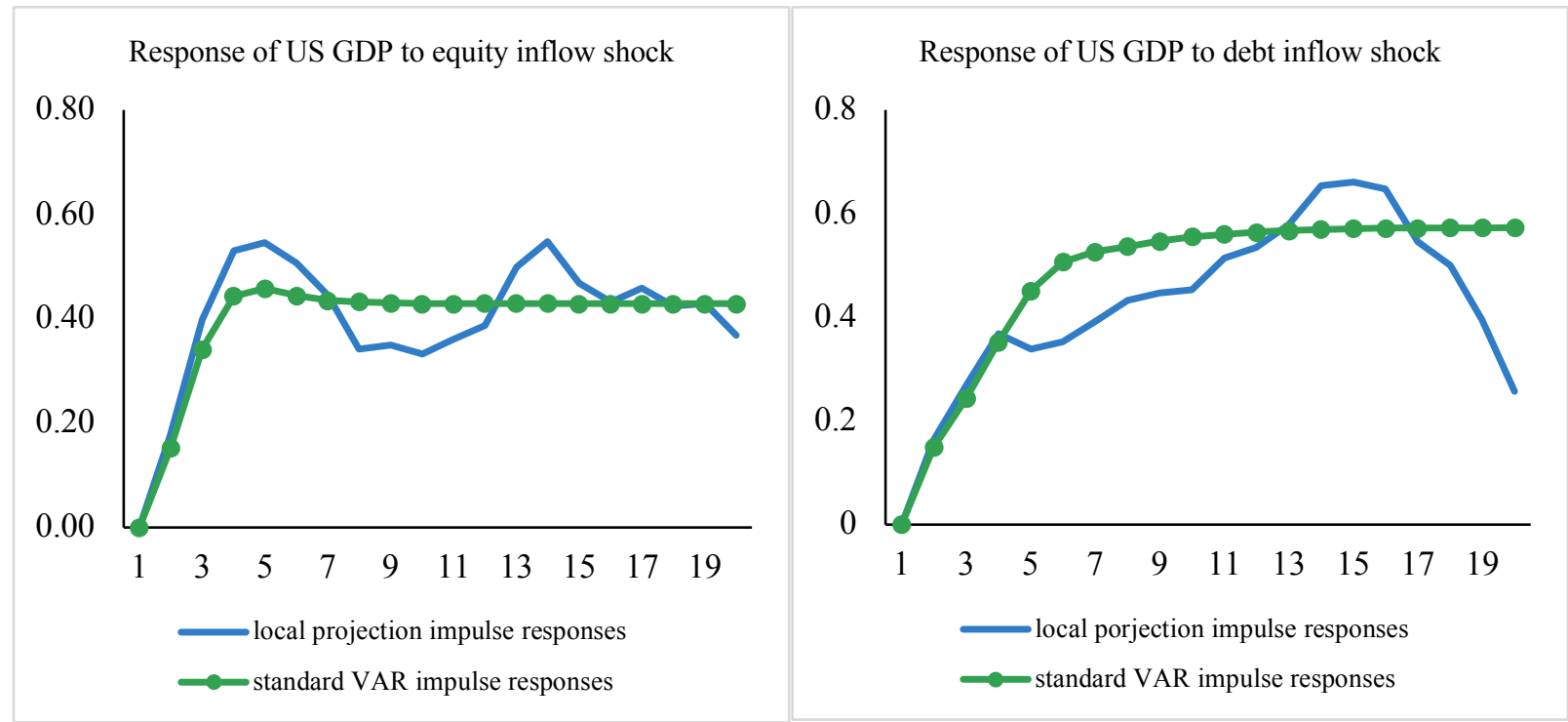
Figure 1-14-LP impulse responses for US GDP, government and corporate debt Panel A: Responses to structural one S.D. innovations
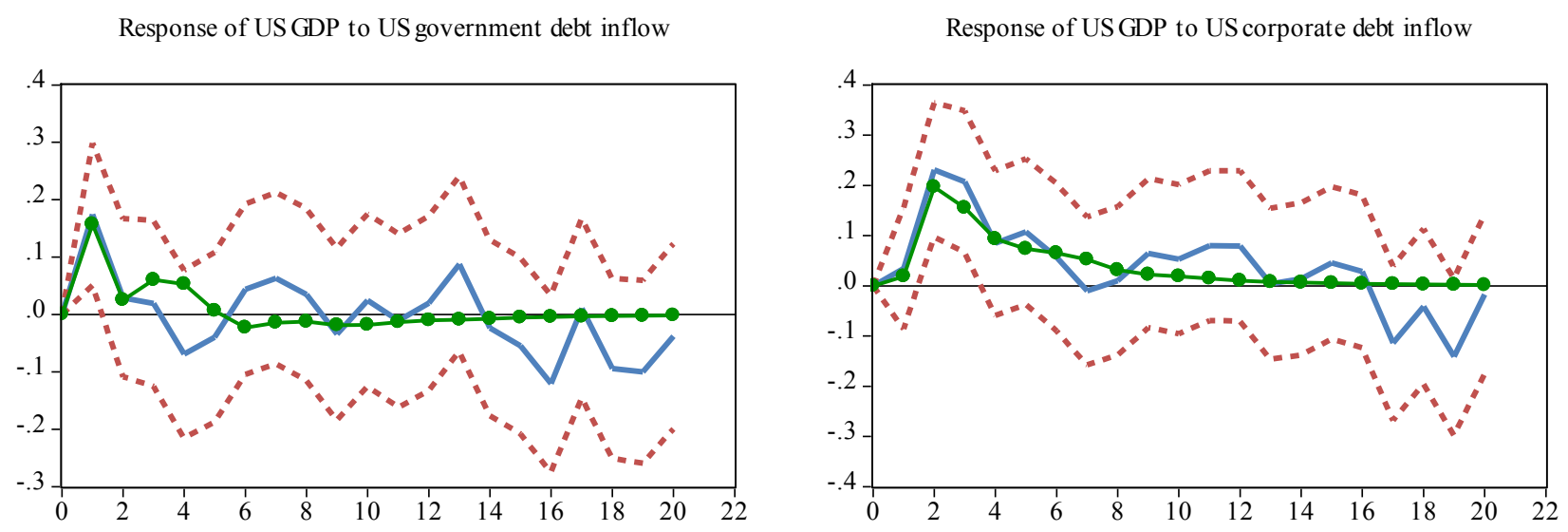

Note: The blue solid lines are the impulse responses calculated by local projections method, red dash lines are two standard error bands for coefficients of local projections responses and the green lines with circles are the impulse response from standard VAR models.

Panel B: Accumulated responses to structural one S.D. innovations

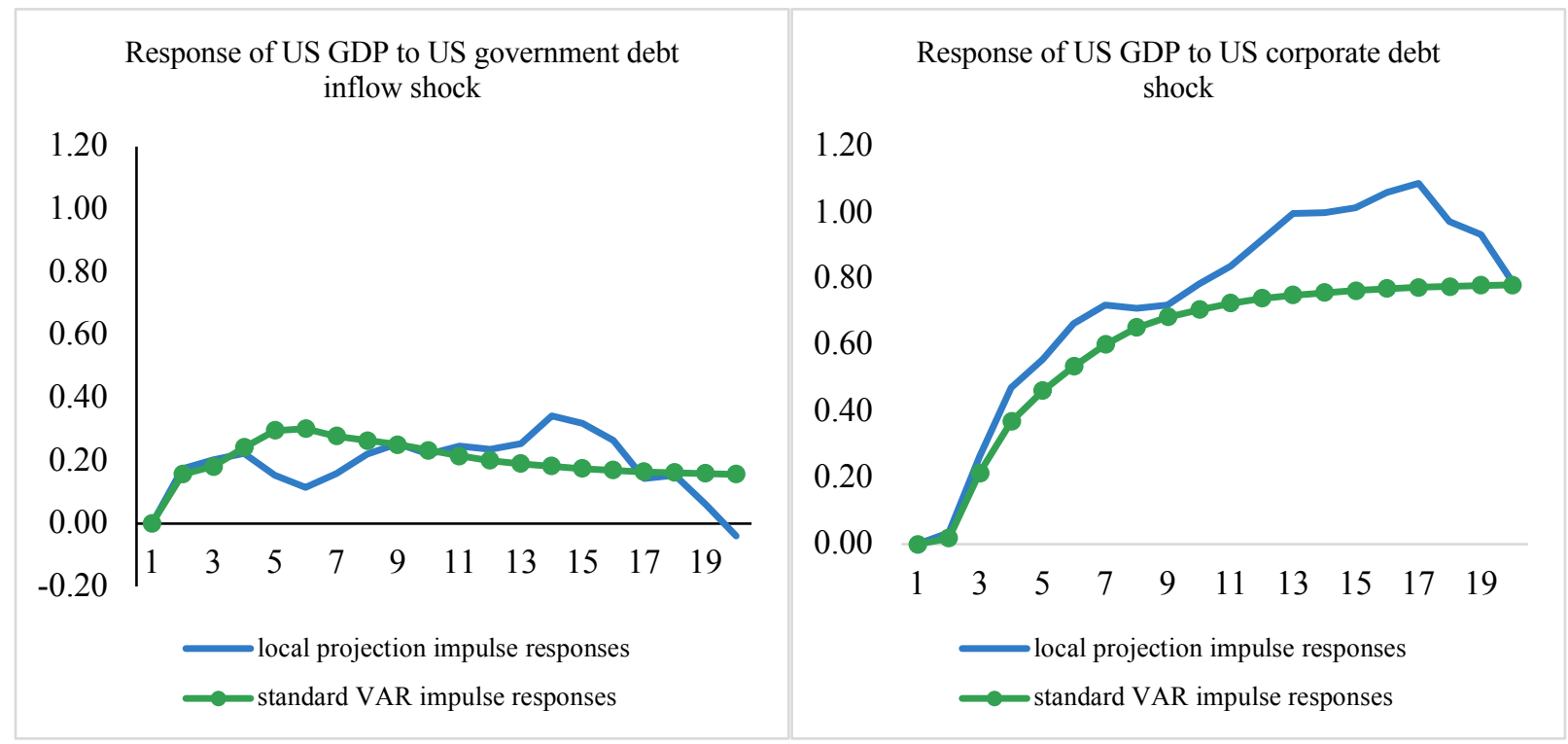


Figure 1-15-FAVAR impulse responses for US GDP and portfolio inflow

Accumulated response to structural one S.D. innovations \pm 2 S.E.

Response of US GDP to portfolio inflow shock

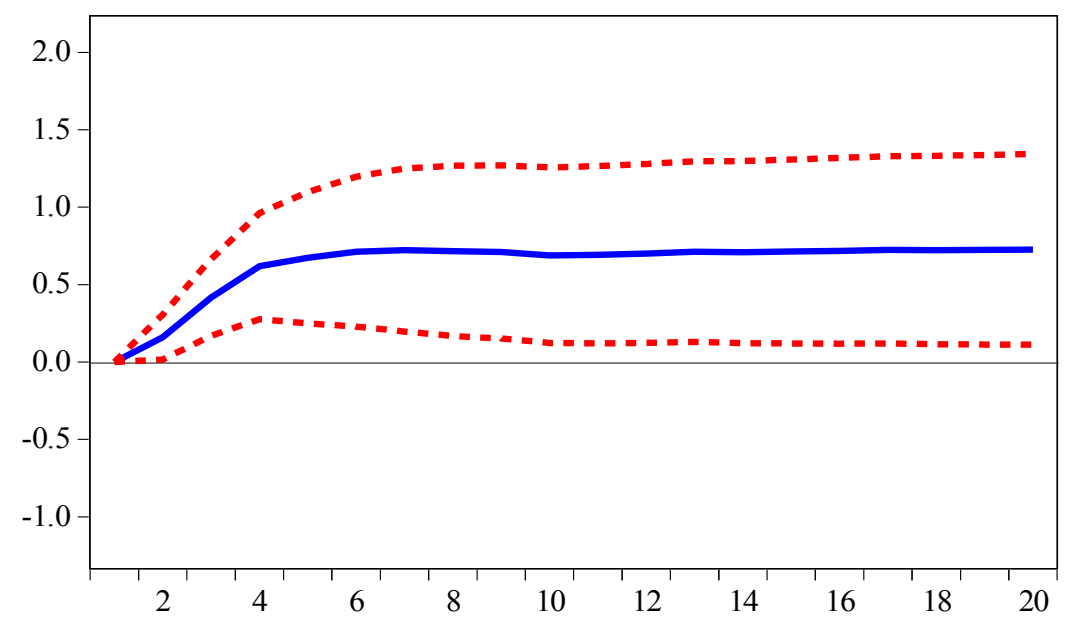


Figure 1-16-FAVAR impulse responses for US GDP, equity inflow and debt inflow Accumulated response to structural one S.D. innovations \pm 2 S.E.

Response of US GDP to equity inflow shock Response of US GDP to debt inflow shock
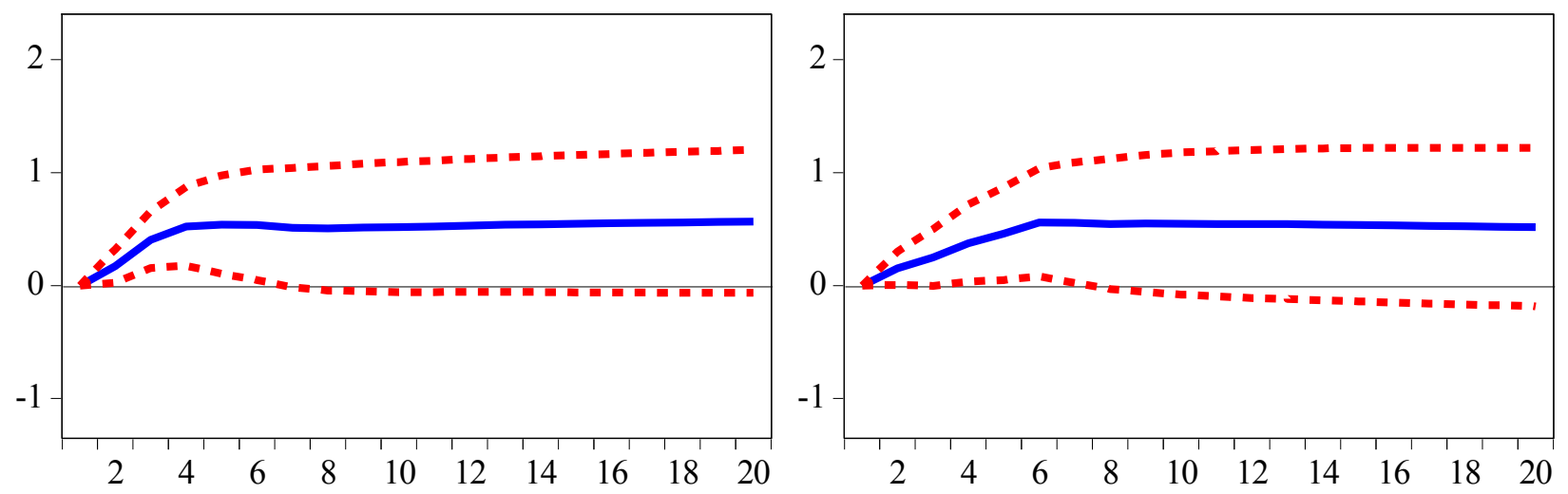
Figure 1-17-FAVAR impulse responses for US GDP, government and corporate debt Accumulated response to structural one S.D. innovations \pm 2 S.E.

Response of US GDP to US government debt inflow shock Response of US GDP to US corporate debt inflow shock
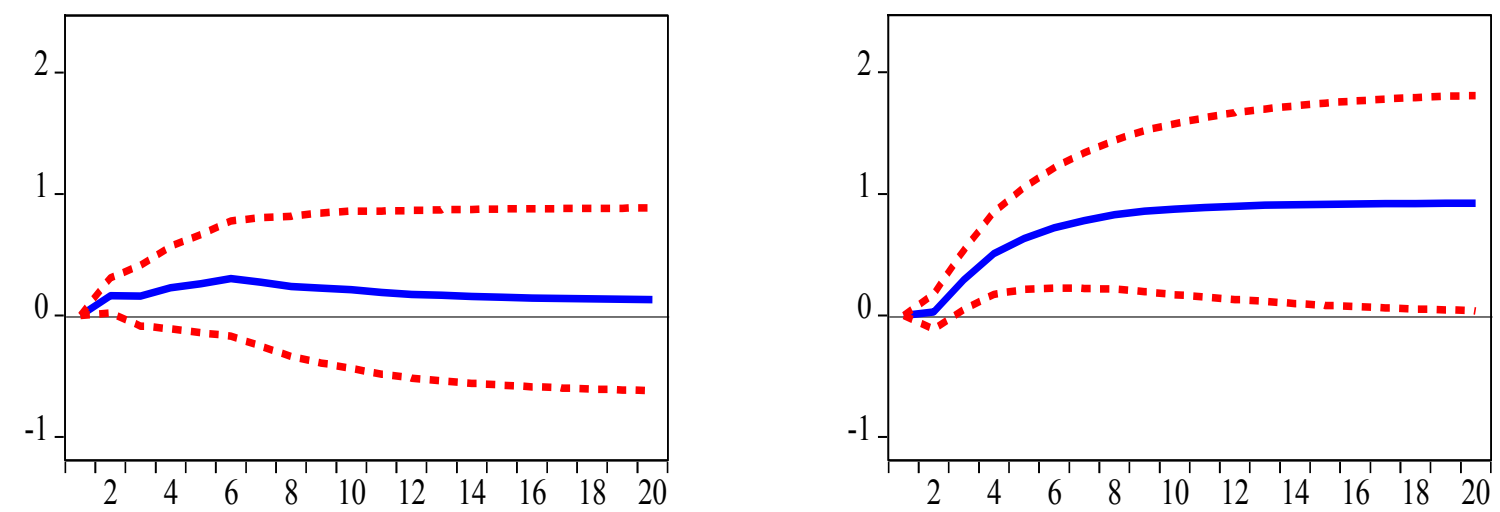


\section{Chapter 2: Forecasting US GDP Growth, Does}

\section{Foreign Investment Matter?}

\subsection{Introduction}

Total foreign investment in the US reached $\$ 24.5$ trillion by the end of the first quarter of 2017. ${ }^{11}$ Despite the volume of foreign capital in the US, there are limited studies that look at the effect of capital inflow on US economy. ${ }^{12}$ Moreover, capital flow variables have not been considered in the forecasting of US GDP. This chapter aims to close that gap by studying whether the inclusion of capital flow variables can improve US GDP forecasts.

We apply the three-pass regression filter (3PRF) method introduced by Kelly and Pruitt (2015) to forecast US GDP using capital inflow and outflow as well as trade variables. We use the disaggregated capital flow series from 1991 Q4 to 2017 Q1 reported in the United States financial accounts. We also consider a number of benchmark models and use the mean square forecast error (MSFE) metric to compare in-sample and out-of-sample forecasts of 3PRF models with the benchmark ones. We use autoregressive (AR) and autoregressive distributed lag (ARDL) models as our benchmarks. These models are commonly used in the literature as benchmarks since they are known to perform well and are hard to beat (Banerjee and Marcellino (2006), Rapach and Strauss (2008), Castle et al. (2013) and Ravazzolo and Rothman (2013)).

\footnotetext{
11 That is the lower bound of total foreign investment where foreign direct investment is valued on current-cost basis. If foreign direct investment is measured at market-value, total US liabilities for the same period goes up to almost $\$ 33$ trillion according to US Bureau of Economic Analysis (BEA).

12 See Warnock and Warnock (2009) for the impact of international capital inflow on US long-term interest rates. They show that US long-term interest rates would have been 80 basis points higher if the international capital inflow was zero for one year.
} 
Our results show that incorporating capital flow variables by employing 3PRF method produces significantly more accurate US GDP forecasts than AR models. Inclusion of capital flow variables can improve in-sample MSFE of autoregressive forecasts by at least 18 percent. In comparison to ARDL models, in-sample 3PRF forecasts perform at least as well as the benchmark models in shorter horizons and better in longer horizons. Inclusion of capital flow and trade information by applying 3PRF can improve MSFE of ARDL models by at least 6 percent in longer horizons. 3PRF out-of-sample forecasts with capital inflow and outflow variables perform significantly better than AR benchmarks in shorter horizons $(h=1,2,4)$ but in longer horizons $(h=8)$ they only marginally outperform AR models. Our results show that 3PRF forecasts outperform ARDL models in the overwhelming majority of cases, although their margins are slim when ARDL models are well-specified.

The first contribution of this chapter is the inclusion of capital flow variables in forecasting US GDP growth. In the forecasting of macroeconomic variables with a large number of predictors, external information is limited to the inclusion of trade series such as exports and imports (e.g. Stock and Watson, 2012), and the importance of foreign investments has been overlooked. The second contribution is estimating US GDP forecasts using 3PRF and comparing them with AR and ARDL models. We show that in-sample and out-of-sample 3PRF forecasts, with capital flow variables, outperform pure autoregressive models for all forecasting horizons. Out-of-sample forecasts of 3PRF models using capital flow and trade variables outperform ARDL models. The improvements are small, however, when ARDL models are well-specified.

The rest of the chapter is structured as follows: Section 2.2 presents brief empirical background on the effect of capital flow on economic growth. In section 2.3, we explain the 3PRF method and our benchmark models. The description of our data source is presented in section 2.4 
Section 2.5 compares 3PRF in-sample and out-of-sample forecasts with the benchmark models, and section 2.6 concludes.

\subsection{Empirical Background on Capital Flow and Growth}

In this section, we look at studies on the effect of capital flow on economic growth. There is a division between the effect of capital inflow on growth suggested by theory and what policy makers in emerging economies believe (Blanchard et al., 2016). Theory suggests that an increase of capital inflow into a country with flexible exchange rate policy puts upward pressure on domestic currency. Therefore, domestic currency appreciates, and the country's current account deteriorates, resulting in lower GDP if the money supply remains unchanged. In practice, an ongoing flow of foreign capital into a country also puts downward pressure on domestic interest rates promoting investment and increasing output. Blanchard et al. (2015) show that increases in non-bond flows and bond-flows have positive and negative impact on output, respectively.

Warnock and Warnock (2009) study the effect of international capital inflow on US longterm interest rates by looking at the effect of foreign-purchased US government bonds on 10-year Treasury yields. They show that if there was no foreign purchase of US government bonds for one year, long-term rates would have been 80 basis points higher. They also find similar effects on US mortgage rates and other long-term interest rates. Their study is conducted before the recent financial crisis, so it does not include post-financial crisis period. Our sample, however, covers pre- and post- financial crisis.

Aizenman et.al (2013) study the effects of international capital flows on economic growth of 100 countries between 1990 and 2010. They find a significant and stable relationship between FDI and growth. However, the relationships between portfolio flows and growth were less stable. They show one standard deviation increases in FDI inflow and outflow increase growth rate of 
GDP per capita by 1.8 and 12.06 percentage points, respectively. They find that a one standard deviation increase of FDI inflow, equity investment and short-term debt during pre-crisis period increase GDP per capita growth by $0.94,0.39$ and zero percentage points, respectively.

Durham (2003) examines the effect of foreign portfolio investment and bank lending on economic growth of 88 countries from 1977 to 2000. His estimations show that portfolio investments and foreign bank lending have no effect and negative impact on growth, respectively. However, he mentions that his results might be affected by simultaneity bias given the use of simultaneous equations. The author shows that one percentage point increases in the ratio of portfolio investments to GDP and foreign bank lending as percentage of GDP reduce average growth rates by 1.4 and 0.15 percentage points, respectively.

\subsection{Forecasting Methods}

In this section, we briefly explain dimension reduction techniques used in macroeconomic forecasting literature, we then describe 3PRF forecasting method in section 2.3.1 and our benchmark forecasts in section 2.3.2.

Stock and Watson (2002) were the first to study large number of predictors in forecasting macroeconomic variables. They use principal component analysis to estimate unobserved latent factors which capture the covariability of the predictors and use them for forecasting macroeconomic series. Principal component method only looks at the predictors, so the extracted factors are the best fit for the predictors and not necessarily the target series. Boivin and $\mathrm{Ng}(2006)$ address the issue with using large number of predictors. They show that in an unscreened large dataset, the factors with high forecasting power can be dominated by other factors. Their forecasting exercise shows that factors extracted from small-sized, pre-screened series of 40 lead to better results compared to factors from large, unscreened series. 
Partial Least Squares (PLS) is an alternative dimension reduction technique introduced by Wold (1982). In PLS latent factors are extracted from the correlation or covariance matrix that includes both target variable and predictors. It took decades for the method to gain momentum in macroeconomic forecasting, but recently it has been used as an alternative dimension reduction technique in forecasting with large dataset (e.g. Fuentes et al. (2015), Groen and Kapetanios (2016) and Carrasco and Rossi (2016)).

\subsubsection{Three-Pass Regression Filter Forecasts}

In this section, we explain 3PRF method introduced by Kelly and Pruitt (2015). They show that 3PRF can be reduced to PLS when: in the first pass the target variable is used as a proxy, predictors are demeaned and standardized and no constant is used in the first two passes. They use the 3PRF method to forecast various macroeconomic variables and show that 3PRF performs best for eight out of thirteen variables. In this chapter, we apply Kelly and Pruitt (2015)'s 3PRF method to estimate both in-sample and out-of-sample forecasts of US GDP using capital inflow, outflow and trade variables. For simplicity, we explain the method for the case where predictors only include capital inflow variables. The same steps can be used even when predictors include additional series such as capital outflow and trade variables. 3PRF estimates can be obtained from a set of three OLS regressions:

First pass is the time series regression where we regress time series of capital inflow predictors on the matrix of proxies one by one:

$x_{i, t}=\phi_{0, i}+z^{\prime} \phi_{i}+\epsilon_{i t}$ for $i=1, \ldots, N$.

Where $x_{i, t}$ is the time series of capital inflow variable $i, \mathbf{z}$ is a $1 \times T$ vector of our single proxy, $\boldsymbol{\phi}_{i}$ is a $1 \times N$ vector of slope coefficients and $N$ is the number of capital inflow predictors. We save the slope estimate $\widehat{\boldsymbol{\phi}}_{i}$. 
In the second pass, we regress cross section of capital inflow predictors on slope estimates obtained from the first pass:

$x_{i, t}=\phi_{0, t}+\widehat{\phi}^{\prime} F_{t}+\varepsilon_{i t}$ for $t=1, \ldots, T$.

$\boldsymbol{F}_{t}$ is a $1 \times T$ vector of slope coefficients and $T$ is number of observations in each time series. We save the slope estimate $\widehat{\boldsymbol{F}}_{t}$.

Finally, in the third pass, we regress one-period ahead of US GDP, our target variable, on predictive factors obtained from the second pass:

$y_{t+1}=\beta_{0}+\widehat{F}^{\prime} \beta+\eta_{t+1}$

Equation (9) provide us with forecasted US GDP, $\hat{y}_{t+1}$.

We used the following auto-proxy algorithm, introduced by Kelly and Pruitt (2015), to select a single proxy that we use in the first pass:

“...

1. Initialize $\boldsymbol{r}_{0}=\boldsymbol{y} . \quad$ For $k=1, \ldots, L$ :

2. Define the $k^{\text {th }}$ automatic proxy to be $r_{k-1}$. Stop if $k=L$; otherwise proceed.

3. Compute the $3 P R F$ for target $\boldsymbol{y}$ using cross section $\boldsymbol{X}$ using statistical proxies 1 through $k$. Denote the resulting forecast $\hat{y}_{k}$.

4. Calculate $r_{k}=y-\hat{y}_{k}$, advance $k$, and go to step 1."

Where $\boldsymbol{y}$ is our target variable, US GDP, $L$ is the number of proxies, that is equal to one, and $\boldsymbol{X}$ is the matrix of capital inflow variables.

Once we estimate $\hat{y}_{t+1}$ we can calculate associated forecasts errors as follows:

$u_{t+1}=y_{t+1}-\widehat{y}_{t+1}$

For $h$-step ahead forecasts, one can just replace $y_{t+1}$ with $y_{t+h}$ as explained by Kelly and Pruitt (2015). However, we define $y_{t+h}=\left(\frac{1}{h}\right) \sum_{j=1}^{h} y_{t+j}$ as the forecast of US GDP over the next $h$ 
quarters so it is consistent with our benchmark models. Therefore, forecast errors for $h$ step ahead forecasts are calculated as follows:

$u_{t+h}=y_{t+h}-\widehat{y}_{t+h}$

We then use these forecast errors to calculate mean square forecast error (MSFE) of 3PRF forecasts.

\subsubsection{Benchmark Forecasts}

In this section, we explain our benchmark forecasts that are used to evaluate 3PRF forecasts. We use ten benchmark forecasts, two autoregressive models (AR (1) and AR (4)), two autoregressive distributed lag models with only gross capital inflow (ARDL $(1,1)$ inflow, ARDL $(4,4)$ inflow), two ARDL models with only net exports (ARDL $(1,1)$ net trade, ARDL $(4,4)$ net trade), two ARDL with both gross capital inflow and outflow variables (ARDL $(1,1,1)$ flows, ARDL $(4,4,4)$ flows) and two ARDL with exports and imports variables (ARDL $(1,1,1)$ trade and ARDL $(4,4,4)$ trade). The $h$ step ahead forecast of the autoregressive models are estimated as follows:

$y_{t+h}^{h}=a+\sum_{j=0}^{p_{1}} b_{j} y_{t-j}+\varepsilon_{t+h}^{h}$

Where $y_{t+h}^{h}=\left(\frac{1}{h}\right) \sum_{j=1}^{h} y_{t+j}$ is the approximate of US GDP over the next $h$ quarters and $p_{1}$ is the number of lags in each AR model (e.g. $p_{1}=1$ for $\mathrm{AR}(1)$ and $p_{1}=4$ for AR (4)). Autoregressive benchmarks especially AR (4) is commonly used in forecasting literature to evaluate the predictive power of more complex methods (e.g. Fuentes et al., 2015).

We also consider ARDL models where in addition to lags of US GDP, lags of aggregate capital flow and trade variables are also included in the models. These benchmarks are used to compare 3PRF forecasts with forecasts obtained from aggregate variables such as gross capital flows and trade. We use four different types of ARDL models: The first type has total capital 
inflow (e.g. ARDL $(1,1)$ inflow), the second type contains net exports (e.g. ARDL $(1,1)$ net trade), the third type includes both total capital inflow and outflow (e.g. ARDL $(1,1,1)$ flows) and the fourth type has both exports and imports (e.g. ARDL $(1,1,1)$ trade). For the first type, we estimate $h$-step ahead forecasts as follows:

$y_{t+h}^{h}=a+\sum_{j=0}^{p_{1}-1} b_{j} y_{t-j} \sum_{j=0}^{p_{2}-1} c_{j}, x_{i n f l o w, t-j}+\varepsilon_{t+h}^{h}$

Where $x_{\text {inflow }}$ is total capital inflow, $p_{1}$ is the lag length of target variable and $p_{2}$ is the lag length of total capital inflow variable. The second type is very similar to the first type, the only difference is that we use net exports instead of total capital inflow:

$y_{t+h}^{h}=a+\sum_{j=0}^{p_{1}-1} b_{j} y_{t-j} \sum_{j=0}^{p_{2}-1} c_{j}, x_{n e t ~ e x p o r t s, t-j}+\varepsilon_{t+h}^{h}$

The third and fourth types have two sets of predictors. The third type contains capital inflow and capital outflow:

$y_{t+h}^{h}=a+\sum_{j=0}^{p_{1}-1} b_{j} y_{t-j} \sum_{j=0}^{p_{2}-1} c_{j}, x_{\text {inflow }, t-j}+\sum_{j=0}^{p_{3}-1} d_{j}, x_{o u t f l o w, t-j}+\varepsilon_{t+h}^{h}$

Where $x_{\text {outflow }}$ is total capital outflow and $p_{3}$ is lag length of total capital outflow. The fourth type is similar to the third type, but it includes exports and imports instead of capital inflow and outflow:

$y_{t+h}^{h}=a+\sum_{j=0}^{p_{1}-1} b_{j} y_{t-j} \sum_{j=0}^{p_{2}-1} c_{j}, x_{\text {exports }, t-j}+\sum_{j=0}^{p_{3}-1} d_{j}, x_{i m p o r t s, t-j}+\varepsilon_{t+h}^{h}$

We consider forecast horizons of 1, 2, 4 and 8 quarters. In-sample forecasts are calculated using the entire sample from 1991 Q4 until 2017 Q1. The recursive out-of-sample forecasts are estimated by dividing the sample in half, where the first half is used to estimate the coefficients and form the initial forecast and the second half is used to evaluate the forecasts.

For each benchmark model, forecast errors are calculated as follows:

$$
u_{t+h}=y_{t+h}^{h}-\widehat{y}_{t+h}^{h}
$$


The benchmark forecast errors are then used to calculate $M S F E_{\text {benchmark }}$. Finally, we compare $M S F E_{3 P R F}$ and $M S F E_{\text {benchmark }}$ by computing $M S F E_{\text {ratio }}$ :

$M S F E_{\text {ratio }}=\frac{M S F E_{3 P R F}}{M S F E_{\text {benchmark }}}$

$M S F E_{\text {ratio }}$ smaller than one indicates that 3PRF forecast performs better than the benchmark model.

\subsection{Data}

The data source of this chapter is Financial Accounts of the United States- Z.1 tables- that are available from Board of Governors of the Federal Reserve System's website. This source contains two sets of data series that are associated with US financial relations with the rest of the world. The first set, the one we use, is presented in table L.133 Rest of the World and contains series on the levels of various US assets held by foreigners and foreign assets held by US residents at the end of each quarter. Second set is presented in table F.133 Rest of the World and include series on the flows of assets and liabilities between US residents and foreign investors in each quarter. In financial accounts flow of assets means the exchange of assets so this table is equivalent to transaction of assets and liabilities in each quarter.

The benefit of this source is that it contains disaggregated data on the components of capital inflow and outflow. Our sample covers the period from 1991 Q4 until 2017 Q1. There are two reasons why we choose to start our sample from 1991. First, prior to 1991 there are multiple series containing zero and after 1991 there is only one series including zero. Second, we preferred our forecast evaluation period to include pre- and post-financial crisis. If we started our sample from 2001, where all series are non-zero, our forecasting evaluation period would start in mid 2009, 
after the financial crisis. So, to avoid that, we opt for 1991 Q4. Appendix 1 and Appendix 3 contain flow charts of capital inflow and capital outflow variables, respectively. ${ }^{13}$

Apart from capital flow variables we also collect US real GDP (billions of chained 2009 dollars) and US GDP deflator $(2009=100)$ from Federal Reserve Bank of St. Louis (FRED) as well as US net exports, exports and imports from US Bureau of Economic Analysis (BEA). All variables are corrected for inflation. Also, all variables have a unit root, so we use annualized growth rates to ensure stationary. Descriptions of capital inflow and capital outflow variables are presented in Table 2-1 and Table 2-2, respectively. And descriptive statistics of all variables are displayed in Table 2-3.

\subsection{Primary Results}

In this section, we present MSFE ratios associated with models introduced in Section 2.2. Table 2-4 shows the performance of 3PRF in-sample forecasts compared to benchmark forecasts. The first column captures MSFE ratios where the numerator is MSFE of 3PRF forecasts using only capital inflow. Note that associated ARDL benchmarks include two types of models: one that includes lags of only total capital inflow and another one that contains lags of net exports. Our results show that 3PRF forecasts with only capital inflow variables perform significantly better than autoregressive models, AR (1) and AR (4), regardless of forecast horizons. 3PRF forecasts perform better than simple autoregressive forecasts by at least 18 percent. In comparison to ARDL models, 3PRF forecasts perform at least as good in short forecasting horizons and significantly better in longer horizons.

${ }^{13}$ We only used the most disaggregated series of each category. 
The second column illustrates MSFE ratios where the numerator is MSFE of 3PRF forecasts using both capital inflow and capital outflow variables and the denominator is the MSFE of associated benchmark models. There are three types of benchmark models in this column. The first type is the autoregressive models. The second type is ARDL models including both capital inflow and outflow variables. And the third type is ARDL models containing exports and imports. 3PRF in-sample forecasts with capital inflow and outflow variables outperform autoregressive benchmark forecasts by at least 21 percent. In short-horizons, 3PRF forecasts, with capital inflow and outflow, perform at least as well as ARDL benchmarks with capital inflow and outflow. In longer horizons, however, 3PRF forecasts perform notably better. 3PRF forecasts perform at least as well as ARDL models with exports and imports.

The third column displays MSFE ratios where the numerator is MSFE of 3PRF forecasts using capital inflow, capital outflow, exports, imports and net exports variables and the denominator is the MSFE of benchmark models, the same as those used in the second column. 3PRF forecasts performs better than autoregressive benchmarks by at least 26 percent. In comparison with ARDL models, 3PRF forecasts perform at least as well in short-horizons and significantly better in longer horizons. 3PRF forecasts that use both capital flow and trade variables outperform 3PRF forecasts that only use capital flow variables.

Table 2-5 displays the comparison between 3PRF out-of-sample forecasts and benchmark forecasts. In forecast horizons of up to a year, out-of-sample 3PRF forecasts perform remarkably better than AR benchmark models. They outperform autoregressive models by at least 14 percent. At longer horizons, 3PRF forecasts only marginally outperform AR models.

Our results show that $3 \mathrm{PRF}$ forecasts outperform ARDL models regardless of forecast horizons. However, when ARDL models are well-specified their MSFEs are close to MSFEs of 
3PRF forecasts. The use of 3PRF on capital flow variables seem to pay off as it results in lower MSFEs in most cases. 3PRF forecasts that use both capital flow and trade variables perform better than 3PRF forecasts that only rely on capital flow variables in all forecasting horizons.

\subsection{Comparison of 3PRF and Principal Components Forecasts}

In this section, we present MSFE ratios where 3PRF forecasts are compared with principal components forecasts. We use the following ARDL framework to incorporate principal components into our forecast:

$y_{t+h}^{h}=a+\sum_{j=0}^{p_{1}-1} b_{j} y_{t-j} \sum_{j=0}^{p_{2}-1} c_{j}, x_{P C 1, t-j}+\varepsilon_{t+h}^{h}$

$x_{P C 1}$ is the first principle component extracted from the associated capital flow variables included in each model.

Table 2-6 shows the comparison between in-sample 3PRF forecasts and principal components ones. In-sample 3PRF forecasts with capital flow and trade variables outperform principal components models by at least 7 percent in shorter horizons forecasts and 19 percent in longer horizons. Table 2-7 illustrates the comparison between out-of-sample 3PRF forecasts and principal components models. Out-of-sample 3PRF forecasts using capital flow and trade variables perform significantly better than principal components models especially in shorter horizons. Outof-sample 3PRF forecasts outperform principal components forecasts by at least 18 percent in shorter horizons and 10 percent in longer horizons.

\subsection{Conclusion}

This chapter aims to forecast US GDP growth using disaggregated financial accounts data. All studies using a large number of predictors to forecast US GDP have one thing in common, they all use time series that mainly consider domestic variables. Although they include trade series such 
as exports and imports, they seem to have overlooked foreign investment variables. Therefore, we aim to bridge that gap by examining whether including capital flow variables improve the conventional autoregressive benchmark forecasts of US GDP.

We use disaggregated capital flow series from 1991 Q4 to 2017 Q1 that are reported in United States financial accounts and incorporate capital flow variables into our forecasts by using 3PRF, the new dimension reduction technique introduced by Kelly and Pruitt (2015). We evaluate 3PRF forecasts by using multiple benchmark models and use the MSFE metric to compare 3PRF forecasts with benchmark forecasts.

We found that 3PRF forecasts, both in-sample and out-of-sample, outperform AR forecasts significantly regardless of forecasting horizons. The only exception is the out-of-sample forecast of eight quarters ahead where 3PRF only marginally performs better than AR benchmarks. In comparison to ARDL models, in-sample 3PRF forecasts perform noticeably better in longer horizons. Our results show that 3PRF forecasts outperform ARDL models in majority of cases, although their margins are slim when ARDL models are well-specified. In-sample and out-ofsample 3PRF forecasts with capital flow and trade variables perform better than benchmark models in all forecasting horizons. Moreover, 3PRF in-sample and out-of-sample forecasts using capital flow and trade variables outperform principal components models regardless of the forecasting horizon. 


\subsection{References}

Aizenman, Joshua, Yothin Jinjarak, and Donghyun Park. 2013. "Capital Flows and Economic Growth in the Era of Financial Integration and Crisis, 1990-2010." Open Economies Review 24 (3): 371-396.

Banerjee, Anindya, and Massimiliano Marcellino. 2006. "Are there any reliable leading indicators for US inflation and GDP growth?" International Journal of Forecasting 22: 137-151.

Blanchard, Olivier, Jonathan D. Ostry, Atish R. Ghosh, and Marcos Chamon. 2015. "Are Capital Inflows Expansionary or Contractionary? Theory, Policy Implications, and Some Evidence." NBER Working Paper No. 21619.

Blanchard, Olivier, Jonathan D. Ostry, Atish R. Ghosh, and Marcos Chamon. 2016. "Capital Flows: Expansionary or Contractionary?" American Economic Review: Papers and Proceedings 565-569.

Boivin, Jean, and Serena Ng. 2006. "Are more data always better for factor analysis?" Journal of Econometrics 132 (1): 169-194.

Carrasco, Marine, and Barbara Rossi. 2016. "In-Sample Inference and Forecasting in Misspecified Factor Models." Journal of Business \& Economic Statistics 34 (3): 313-338.

Castle, Jennifer L., Michael P. Clements, and David F. Hendry. 2013. "Forecasting by factors, by variables, by both or neither?" Journal of Econometrics 177 (2): 305-319.

Durham, Benson J. 2003. "Foreign Portfolio Investment, Foreign Bank Lending, and Economic Growth." Board of Governors of the Federal Reserve System International Finance Discussion Papers No. 757. 
Fuentes, Julieta, Pilar Poncela, and Julio Rodríguez. 2015. "Sparse Partial Least Squares in Time Series for Macroeconomic Forecasting." Journal of Applied Econometrics 30 (4): 576-595.

Groen, Jan J.J., and George Kapetanios. 2016. "Revisiting useful approaches to data-rich macroeconomic forecasting." Computational Statistics and Data Analysis 100: 221-239.

Kelly, Bryan, and Seth Pruitt. 2015. "The three-pass regression filter: A new approach to forecasting using many predictors." Journal of Econometrics 186 (2): 294-316.

Rapach, David E., and Jack K. Strauss. 2008. "Forecasting US Employment Growth Using Forecast Combining Methods." Journal of Forecasting 27 (1): 75-93.

Ravazzolo, Francesco, and Philip Rothman. 2013. "Oil and US GDP: A Real-Time Out-of Sample Examination." Journal of Money, Credit and Banking 45 (2-3): 449-463.

Stock, James H., and Mark W. Watson. 2002. "Forecasting Using Principal Components from a Large Number of Predictors." Journal of the American Statistical Association 97 (460): 1167-1179.

Stock, James H., and Mark W. Watson. 2012. "Generalized Shrinkage Methods for Forecasting Using Many Predictors." Journal of Business \& Economic Statistics 30 (4): 481-493.

Warnock, Francis E., and Veronica Cacdac Warnock. 2009. "International capital flows and US interest rates." Journal of International Money and Finance 28: 903-919.

Wold, Herman. 1982. "Soft Modeling, The Basic Design and Some Extensions." System Under Indiect Observation, in: Jöreskog, K.-G., Wold, H. ed. 
Table 2-1-Description of capital inflow variables

\begin{tabular}{|c|c|}
\hline Capital inflow variables & Brief description \\
\hline SDR allocations & Federal government; special drawing rights (SDR) allocations \\
\hline Net interbank & Net interbank transactions with banks in foreign countries \\
\hline US checkable deposits and currency & US checkable deposits and currency \\
\hline US time deposits & US total time and savings deposits including negotiable certificates of deposit \\
\hline Money market fund shares & US money market mutual fund shares \\
\hline Security repurchased agreements & $\begin{array}{l}\text { Security repurchased agreements including transactions with deposit-taking institutions excluding } \\
\text { the central bank, deposits, of which resale agreement. Also, transactions with other financial } \\
\text { institutions excluding general government, loans, of which: resale agreements. Level is calculated } \\
\text { as the previous level plus the unadjusted flow. }\end{array}$ \\
\hline Open market paper & Commercial paper and other securities, short term debt securities. \\
\hline Treasury bills & Treasury bills and certificates \\
\hline Other Treasury securities & $\begin{array}{l}\text { Other Treasury securities, including Treasury Bonds and Notes and excluding Treasury bills and } \\
\text { certificates. }\end{array}$ \\
\hline Agency and GSE backed securities & Agency-and GSE- (Government-Sponsored Enterprises) backed securities \\
\hline Municipal securities & Municipal securities including state and local government securities. \\
\hline US corporate bonds & $\begin{array}{l}\text { Corporate and foreign bonds including corporate bonds issued by Netherlands Antillean Financial } \\
\text { subsidiaries of US corporations. }\end{array}$ \\
\hline Loans to US corporate business & $\begin{array}{l}\text { US nonfinancial business loans including loans secured by real estate and commercial and industrial } \\
\text { loans. }\end{array}$ \\
\hline US corporate equities & US corporate equities \\
\hline Mutual fund shares & $\begin{array}{l}\text { US mutual fund shares excluding estimated holding of ETFs (Exchange Traded Funds), REITs } \\
\text { (Real Estate Investment Trusts) and hedge fund, private equity and limited partner private fund } \\
\text { shares }\end{array}$ \\
\hline Trade receivables & Trade receivables including trade credit and advances \\
\hline Foreign direct investment in US & Foreign direct investment in the US at current cost \\
\hline
\end{tabular}

Source: Financial Accounts of the United States from Board of Governors of the Federal Reserve System 
Table 2-2- Description of capital outflow variables

\begin{tabular}{|l|l|}
\hline Capital outflow variables & Brief description \\
\hline US official reserve assets & $\begin{array}{l}\text { US official reserve assets including SDRs holding, reserve position in IMF and other US reserve } \\
\text { assets }\end{array}$ \\
\hline US private deposits & US private deposits, including short-term and long-term negotiable certificates of deposit \\
\hline Security repurchase agreements & $\begin{array}{l}\text { Security repurchased agreements including transactions with deposit-taking institutions excluding } \\
\text { the central bank, deposits, of which resale agreement. Also, transactions with other financial } \\
\text { institutions excluding general government, loans, of which: resale agreements. Level is calculated } \\
\text { as the previous level plus the unadjusted flow. }\end{array}$ \\
\hline Commercial paper & Commercial paper issued by financial and nonfinancial firms \\
\hline Bonds & Long-term and short-term securities less negotiable certificates of deposits and commercial paper \\
\hline Depository institution loans & $\begin{array}{l}\text { Depository institution loans to foreign official institutions, foreign banks and foreigners other than } \\
\text { foreign official institutions and foreign banks }\end{array}$ \\
\hline Other loans and advances & $\begin{array}{l}\text { US government loans excluding capital subscriptions and contributions to international financial } \\
\text { institutions and the IMF, customer's liability on acceptances outstanding to commercial banking } \\
\text { and other loans and advances due from foreign addressees. }\end{array}$ \\
\hline Trade payables & Trade credit and advances \\
\hline US direct investment abroad & US direct investment abroad including Netherlands Antillean subsidiaries at current cost \\
\hline US equity in IBRD & Capital subscriptions and contributions to international financial institutions \\
\hline Nonofficial foreign currencies & Nonofficial US currencies \\
\hline Investment by holding companies & Net transactions due to holding companies \\
\hline $\begin{array}{l}\text { Market value of foreign equities } \\
\text { held by US residents }\end{array}$ & Foreign corporate equities including foreign investment fund shares \\
\hline
\end{tabular}

Source: Financial Accounts of the United States from Board of Governors of the Federal Reserve System 
Table 2-3- Descriptive Statistics of variables

\begin{tabular}{|c|c|c|c|c|}
\hline Variables & Mean & Max & Min & Std. Dev. \\
\hline US GDP & 2.48 & 7.48 & -8.54 & 2.39 \\
\hline Total capital inflow & 0.52 & 2.02 & -1.02 & 0.56 \\
\hline Total capital outflow & 0.48 & 2.49 & -2.63 & 0.93 \\
\hline Exports & 3.13 & 25.71 & -41.91 & 10.35 \\
\hline Imports & 3.94 & 26.81 & -66.61 & 12.17 \\
\hline Net exports & 13.65 & 235.12 & -136.63 & 47.71 \\
\hline \multicolumn{5}{|l|}{ US Assets held by foreigners } \\
\hline SDR allocations & 5.80 & 798.33 & -30.17 & 79.94 \\
\hline Net interbank & 89.99 & 9353.03 & -8889.53 & 3269.61 \\
\hline US checkable deposits currency & 6.49 & 65.08 & -31.96 & 11.35 \\
\hline US time deposits & 7.80 & 460.46 & -111.87 & 49.96 \\
\hline Money market fund shares & 14.33 & 80.27 & -17.85 & 18.70 \\
\hline Security repurchased agreements & 12.15 & 273.64 & -195.66 & 59.59 \\
\hline Open market paper & 8.35 & 170.70 & -137.58 & 44.43 \\
\hline Treasury bills & 5.29 & 162.05 & -82.52 & 34.50 \\
\hline Other Treasury securities & 8.83 & 36.26 & -41.24 & 13.05 \\
\hline Agency and GSE backed securities & 9.27 & 81.82 & -45.66 & 21.02 \\
\hline Municipal securities & 12.40 & 77.34 & -20.57 & 15.88 \\
\hline US corporate bonds & 8.91 & 53.45 & -50.27 & 14.10 \\
\hline Loans to US corporate business & -0.16 & 97.35 & -73.75 & 30.05 \\
\hline US corporate equities & 10.17 & 73.12 & -102.52 & 32.10 \\
\hline Mutual fund shares & 19.58 & 275.13 & -113.88 & 47.68 \\
\hline Trade receivables & 4.16 & 64.46 & -105.60 & 25.26 \\
\hline Foreign direct investment in US & 6.08 & 55.24 & -19.87 & 9.00 \\
\hline \multicolumn{5}{|l|}{ Foreign assets held by US residents } \\
\hline US official reserve assets & 0.15 & 224.67 & -54.92 & 30.85 \\
\hline US private deposits & -0.33 & 87.03 & -62.82 & 24.43 \\
\hline Security repurchase agreements & 53.30 & 4796.48 & -226.97 & 476.03 \\
\hline Commercial paper & 4.38 & 138.51 & -178.44 & 38.33 \\
\hline Bonds & 8.83 & 147.61 & -54.01 & 23.94 \\
\hline Depository institution loans & 2.85 & 40.16 & -68.88 & 18.10 \\
\hline Other loans and advances & -3.28 & 160.88 & -35.91 & 20.98 \\
\hline Trade payables & 2.13 & 114.33 & -54.54 & 26.30 \\
\hline US direct investment abroad & 6.77 & 34.99 & -14.73 & 6.95 \\
\hline US equity in IBRD & 2.44 & 13.85 & -2.15 & 3.37 \\
\hline Nonofficial foreign currencies & 4.98 & 1395.02 & -637.81 & 225.19 \\
\hline Investment by holding companies & 7.68 & 7953.17 & -7731.56 & 1112.61 \\
\hline Market value of foreign equities & 11.36 & 101.60 & -112.52 & 38.35 \\
\hline
\end{tabular}

Note: Full sample is 1991 Q4 - 2017 Q1. All variables are transformed to annualized growth rate and corrected for inflation 
Table 2-4- In-sample 3PRF forecasts of US GDP growth

\begin{tabular}{|c|c|c|c|c|c|}
\hline MSFE ratios & $\begin{array}{l}\text { 3PRF-capital } \\
\text { inflow only (1) }\end{array}$ & MSFE ratios & $\begin{array}{l}\text { 3PRF-capital inflow } \\
\text { and outflow (2) }\end{array}$ & MSFE ratios & $\begin{array}{l}\text { 3PRF-capital inflow, } \\
\text { outflow and trade (3) }\end{array}$ \\
\hline \multicolumn{6}{|c|}{$h=1$} \\
\hline $\mathrm{AR}(1)$ & 0.78 & AR (1) & 0.75 & AR (1) & 0.70 \\
\hline AR (4) & 0.82 & AR (4) & 0.79 & AR (4) & 0.74 \\
\hline ARDL $(1,1)$ inflow & 0.86 & $\operatorname{ARDL}(1,1,1)$ flows & 0.85 & $\operatorname{ARDL}(1,1,1)$ flows & 0.80 \\
\hline ARDL $(4,4)$ inflow & 0.97 & $\operatorname{ARDL}(4,4,4)$ flows & 0.99 & ARDL $(4,4,4)$ flows & 0.92 \\
\hline ARDL $(1,1)$ net trade & 0.88 & $\operatorname{ARDL}(1,1,1)$ trade & 0.91 & $\operatorname{ARDL}(1,1,1)$ trade & 0.85 \\
\hline ARDL $(4,4)$ net trade & 0.97 & ARDL $(4,4,4)$ trade & 1.03 & ARDL $(4,4,4)$ trade & 0.97 \\
\hline \multicolumn{6}{|l|}{ 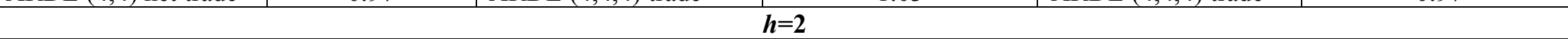 } \\
\hline AR (1) & 0.79 & AR (1) & 0.73 & AR (1) & 0.71 \\
\hline AR (4) & 0.81 & $\mathrm{AR}(4)$ & 0.75 & AR (4) & 0.72 \\
\hline ARDL $(1,1)$ inflow & 0.90 & $\operatorname{ARDL}(1,1,1)$ flows & 0.85 & $\operatorname{ARDL}(1,1,1)$ flows & 0.82 \\
\hline ARDL $(4,4)$ inflow & 1.00 & $\operatorname{ARDL}(4,4,4)$ flows & 0.97 & ARDL $(4,4,4)$ flows & 0.93 \\
\hline $\operatorname{ARDL}(1,1)$ net trade & 0.80 & $\operatorname{ARDL}(1,1,1)$ trade & 0.86 & $\operatorname{ARDL}(1,1,1)$ trade & 0.83 \\
\hline ARDL $(4,4)$ net trade & 0.90 & ARDL $(4,4,4)$ trade & 0.98 & ARDL $(4,4,4)$ trade & 0.94 \\
\hline \multicolumn{6}{|l|}{ 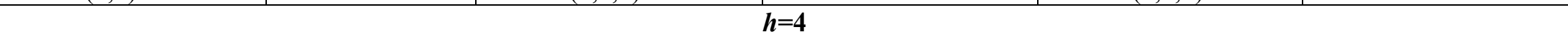 } \\
\hline AR (1) & 0.72 & AR (1) & 0.67 & AR (1) & 0.65 \\
\hline AR (4) & 0.72 & AR (4) & 0.68 & AR (4) & 0.66 \\
\hline ARDL $(1,1)$ inflow & 0.80 & $\operatorname{ARDL}(1,1,1)$ flows & 0.75 & $\operatorname{ARDL}(1,1,1)$ flows & 0.74 \\
\hline ARDL $(4,4)$ inflow & 0.87 & $\operatorname{ARDL}(4,4,4)$ flows & 0.87 & $\operatorname{ARDL}(4,4,4)$ flows & 0.85 \\
\hline $\operatorname{ARDL}(1,1)$ net trade & 0.73 & $\operatorname{ARDL}(1,1,1)$ trade & 0.75 & $\operatorname{ARDL}(1,1,1)$ trade & 0.74 \\
\hline ARDL $(4,4)$ net trade & 0.76 & ARDL $(4,4,4)$ trade & 0.83 & ARDL $(4,4,4)$ trade & 0.81 \\
\hline \multicolumn{6}{|c|}{$h=8$} \\
\hline AR (1) & 0.79 & AR (1) & 0.75 & AR (1) & 0.70 \\
\hline AR (4) & 0.80 & $\mathrm{AR}(4)$ & 0.76 & AR (4) & 0.71 \\
\hline ARDL $(1,1)$ inflow & 0.81 & $\operatorname{ARDL}(1,1,1)$ flows & 0.77 & $\operatorname{ARDL}(1,1,1)$ flows & 0.73 \\
\hline ARDL $(4,4)$ inflow & 0.85 & $\operatorname{ARDL}(4,4,4)$ flows & 0.91 & $\operatorname{ARDL}(4,4,4)$ flows & 0.85 \\
\hline $\operatorname{ARDL}(1,1)$ net trade & 0.82 & $\operatorname{ARDL}(1,1,1)$ trade & 0.90 & $\operatorname{ARDL}(1,1,1)$ trade & 0.84 \\
\hline ARDL $(4,4)$ net trade & 0.91 & ARDL $(4,4,4)$ trade & 1.00 & ARDL $(4,4,4)$ trade & 0.94 \\
\hline
\end{tabular}

Note: Full sample is 1991Q4-2017Q1 
Table 2-5- Out-of-sample 3PRF forecasts of US GDP growth

\begin{tabular}{|c|c|c|c|c|c|}
\hline MSFE ratios & $\begin{array}{l}\text { 3PRF-capital } \\
\text { inflow only (1) }\end{array}$ & MSFE ratios & $\begin{array}{l}\text { 3PRF-capital inflow } \\
\text { and outflow (2) }\end{array}$ & MSFE ratios & $\begin{array}{l}\text { 3PRF- capital inflow, } \\
\text { outflow and trade (3) }\end{array}$ \\
\hline \multicolumn{6}{|c|}{$h=1$} \\
\hline AR (1) & 0.86 & AR (1) & 0.81 & AR (1) & 0.74 \\
\hline AR (4) & 0.81 & AR (4) & 0.76 & AR (4) & 0.69 \\
\hline ARDL $(1,1)$ inflow & 0.98 & $\operatorname{ARDL}(1,1,1)$ flows & 0.91 & ARDL $(1,1,1)$ flows & 0.83 \\
\hline ARDL $(4,4)$ inflow & 0.89 & $\operatorname{ARDL}(4,4,4)$ flows & 0.83 & ARDL $(4,4,4)$ flows & 0.76 \\
\hline ARDL $(1,1)$ net trade & 1.00 & $\operatorname{ARDL}(1,1,1)$ trade & 0.98 & $\operatorname{ARDL}(1,1,1)$ trade & 0.89 \\
\hline ARDL $(4,4)$ net trade & 0.94 & $\operatorname{ARDL}(4,4,4)$ trade & 0.78 & ARDL $(4,4,4)$ trade & 0.72 \\
\hline \multicolumn{6}{|c|}{$h=2$} \\
\hline AR (1) & 0.84 & AR (1) & 0.87 & AR (1) & 0.81 \\
\hline $\mathrm{AR}(4)$ & 0.72 & AR (4) & 0.74 & AR (4) & 0.70 \\
\hline ARDL $(1,1)$ inflow & 0.91 & $\operatorname{ARDL}(1,1,1)$ flows & 0.92 & $\operatorname{ARDL}(1,1,1)$ flows & 0.86 \\
\hline ARDL $(4,4)$ inflow & 0.78 & $\operatorname{ARDL}(4,4,4)$ flows & 0.80 & ARDL $(4,4,4)$ flows & 0.75 \\
\hline ARDL $(1,1)$ net trade & 0.93 & $\operatorname{ARDL}(1,1,1)$ trade & 0.99 & $\operatorname{ARDL}(1,1,1)$ trade & 0.93 \\
\hline ARDL $(4,4)$ net trade & 0.75 & ARDL $(4,4,4)$ trade & 0.75 & ARDL $(4,4,4)$ trade & 0.71 \\
\hline \multicolumn{6}{|c|}{ 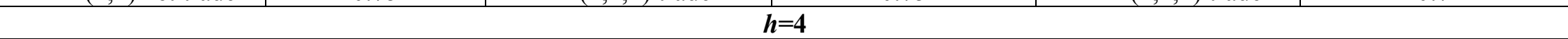 } \\
\hline $\mathrm{AR}(1)$ & 0.79 & AR (1) & 0.81 & $\mathrm{AR}(1)$ & 0.78 \\
\hline AR (4) & 0.72 & AR (4) & 0.74 & AR (4) & 0.71 \\
\hline ARDL $(1,1)$ inflow & 0.85 & $\operatorname{ARDL}(1,1,1)$ flows & 0.84 & $\operatorname{ARDL}(1,1,1)$ flows & 0.81 \\
\hline ARDL $(4,4)$ inflow & 0.74 & $\operatorname{ARDL}(4,4,4)$ flows & 0.73 & $\operatorname{ARDL}(4,4,4)$ flows & 0.70 \\
\hline ARDL $(1,1)$ net trade & 0.81 & $\operatorname{ARDL}(1,1,1)$ trade & 0.86 & ARDL $(1,1,1)$ trade & 0.82 \\
\hline ARDL $(4,4)$ net trade & 0.76 & ARDL $(4,4,4)$ trade & 0.65 & ARDL $(4,4,4)$ trade & 0.63 \\
\hline \multicolumn{6}{|l|}{ H } \\
\hline AR (1) & 0.96 & $\mathrm{AR}(1)$ & 0.95 & AR (1) & 0.91 \\
\hline AR (4) & 0.95 & AR (4) & 0.94 & AR (4) & 0.90 \\
\hline ARDL $(1,1)$ inflow & 0.97 & $\operatorname{ARDL}(1,1,1)$ flows & 0.95 & $\operatorname{ARDL}(1,1,1)$ flows & 0.90 \\
\hline ARDL $(4,4)$ inflow & 0.75 & $\operatorname{ARDL}(4,4,4)$ flows & 0.73 & $\operatorname{ARDL}(4,4,4)$ flows & 0.70 \\
\hline ARDL $(1,1)$ net trade & 0.99 & $\operatorname{ARDL}(1,1,1)$ trade & 0.93 & $\operatorname{ARDL}(1,1,1)$ trade & 0.89 \\
\hline ARDL $(4,4)$ net trade & 0.99 & ARDL $(4,4,4)$ trade & 0.67 & ARDL $(4,4,4)$ trade & 0.65 \\
\hline
\end{tabular}

Note: Full sample is 1991Q4-2017Q1. Recursive procedure starts out-of-sample forecasts halfway through the sample. 
Table 2-6- Comparison of in-sample forecasts of 3PRF and principal components

\begin{tabular}{|c|c|c|c|c|c|}
\hline MSFE ratios ${ }^{1}$ & $\begin{array}{l}\text { 3PRF-capital } \\
\text { inflow only (1) }\end{array}$ & MSFE ratios ${ }^{2}$ & $\begin{array}{l}\text { 3PRF-capital inflow } \\
\text { and outflow (2) }\end{array}$ & MSFE ratios ${ }^{3}$ & $\begin{array}{l}\text { 3PRF- capital inflow, } \\
\text { outflow and trade (3) }\end{array}$ \\
\hline \multicolumn{6}{|c|}{$h=1$} \\
\hline ARDL $(1,1)$ PC1 & 0.79 & ARDL $(1,1)$ PC1 & 0.96 & ARDL $(1,1)$ PC1 & 0.89 \\
\hline $\operatorname{ARDL}(4,4)$ PC1 & 0.92 & ARDL $(4,4)$ PC1 & 1.03 & ARDL $(4,4)$ PC1 & 0.93 \\
\hline \multicolumn{6}{|c|}{$h=2$} \\
\hline ARDL $(1,1)$ PC1 & 0.94 & ARDL $(1,1)$ PC1 & 0.92 & ARDL $(1,1)$ PC1 & 0.83 \\
\hline ARDL $(4,4)$ PC1 & 0.98 & ARDL $(4,4) \mathrm{PC} 1$ & 0.96 & ARDL $(4,4)$ PC1 & 0.86 \\
\hline \multicolumn{6}{|c|}{$h=4$} \\
\hline ARDL $(1,1)$ PC1 & 0.78 & $\operatorname{ARDL}(1,1) \mathrm{PC} 1$ & 0.77 & ARDL $(1,1)$ PC1 & 0.71 \\
\hline ARDL $(4,4)$ PC1 & 0.83 & ARDL $(4,4)$ PC1 & 0.81 & ARDL $(4,4)$ PC1 & 0.75 \\
\hline \multicolumn{6}{|c|}{$h=8$} \\
\hline ARDL $(1,1)$ PC1 & 0.79 & ARDL $(1,1)$ PC1 & 0.76 & ARDL $(1,1)$ PC1 & 0.70 \\
\hline ARDL $(4,4)$ PC1 & 0.92 & ARDL $(4,4) \mathrm{PC} 1$ & 0.83 & ARDL $(4,4)$ PC1 & 0.81 \\
\hline
\end{tabular}

Note: Full sample is 1991Q4-2017Q1. PC1 means lags of the first principal component was included in the model. Therefore, ARDL $(4,4)$ PC1 represents the model with 4 lags of US GDP and 4 lags of the first principal component.

${ }^{1}$ The numerator contains MSFE of principal components using only capital inflow variables

${ }^{2}$ The numerator contains MSFE of principal components using both capital inflow and capital outflow variables

${ }^{3}$ The numerator contains MSFE of principal components using capital inflow, capital outflow and trade variables 
Table 2-7- Comparison of out-of-sample forecasts of 3PRF and principal components

\begin{tabular}{|c|c|c|c|c|c|}
\hline MSFE ratios ${ }^{1}$ & $\begin{array}{l}\text { 3PRF-capital } \\
\text { inflow only (1) }\end{array}$ & MSFE ratios ${ }^{2}$ & $\begin{array}{l}\text { 3PRF-capital inflow } \\
\text { and outflow (2) }\end{array}$ & MSFE ratios ${ }^{3}$ & $\begin{array}{l}\text { 3PRF- capital inflow, } \\
\text { outflow and trade (3) }\end{array}$ \\
\hline \multicolumn{6}{|c|}{$h=1$} \\
\hline ARDL $(1,1)$ PC1 & 0.94 & ARDL $(1,1)$ PC1 & 0.93 & ARDL $(1,1)$ PC1 & 0.81 \\
\hline ARDL $(4,4)$ PC1 & 0.70 & $\operatorname{ARDL}(4,4)$ PC1 & 0.86 & $\operatorname{ARDL}(4,4) \mathrm{PC} 1$ & 0.71 \\
\hline \multicolumn{6}{|c|}{$h=2$} \\
\hline ARDL $(1,1)$ PC1 & 0.89 & ARDL $(1,1)$ PC1 & 0.94 & ARDL $(1,1)$ PC1 & 0.82 \\
\hline ARDL $(4,4)$ PC1 & 0.79 & ARDL $(4,4)$ PC1 & 0.74 & ARDL $(4,4)$ PC1 & 0.73 \\
\hline \multicolumn{6}{|c|}{$h=4$} \\
\hline ARDL $(1,1)$ PC1 & 0.81 & ARDL $(1,1)$ PC1 & 0.85 & ARDL $(1,1)$ PC1 & 0.77 \\
\hline ARDL $(4,4)$ PC1 & 0.92 & $\operatorname{ARDL}(4,4)$ PC1 & 0.81 & $\operatorname{ARDL}(4,4) \mathrm{PC} 1$ & 0.70 \\
\hline \multicolumn{6}{|c|}{$h=8$} \\
\hline ARDL $(1,1)$ PC1 & 0.94 & ARDL $(1,1)$ PC1 & 1.01 & ARDL $(1,1)$ PC1 & 0.90 \\
\hline ARDL $(4,4)$ PC1 & 0.70 & $\operatorname{ARDL}(4,4)$ PC1 & 0.88 & $\operatorname{ARDL}(4,4) \mathrm{PC} 1$ & 0.67 \\
\hline
\end{tabular}

Note: Full sample is 1991Q4-2017Q1. Recursive procedure starts out-of-sample forecasts halfway through the sample. PC1 means lags of the first principal component was included in the model. Therefore, ARDL $(4,4)$ PC1 represents the model with 4 lags of US GDP and 4 lags of the first principal component.

${ }^{1}$ The numerator contains MSFE of principal components using only capital inflow variables

${ }^{2}$ The numerator contains MSFE of principal components using both capital inflow and capital outflow variables

${ }^{3}$ The numerator contains MSFE of principal components using capital inflow, capital outflow and trade variables 


\section{Chapter 3: Foreign Portfolio Investment and the Real Economy in the United Kingdom}

\subsection{Introduction}

Foreign investment in the UK reached over $\$ 10$ trillion at the end of 2016. The share of portfolio inflow has increased from less than 20 percent in the mid 1980s to the current level of 37 percent. The capital flow literature focuses on emerging economies, and a limited number of studies concentrate on how foreign investment affects advanced economies. The first chapter's results show that shocks to portfolio investment and its components have positive and significant impact on US GDP in the long-run. This chapter studies the effect of portfolio investment and its components on UK GDP. There are two reasons for choosing the UK economy, first, the United Kingdom's economy is significantly smaller than the United States', so the concern that our results might be driven due to the size of the US economy can be addressed. Second, the UK foreign investment dataset goes back to the mid-1980s, so a time series analysis similar to the one presented for the US economy is possible.

This chapter uses structural VAR models to study the dynamic effects of portfolio investment on the UK economy. There are two benefits to this method. Firstly, it considers the feedback effects between the variables of interest. Secondly, it facilitates the study of the longterm effects of shocks to portfolio inflow variables on UK economy. The chapter also uses factor augmented VAR (FAVAR) method to investigate whether the inclusion of UK monetary policy component would change the main results. In addition to UK GDP, it studies the long-term effects of foreign portfolio investment on UK domestic investment and consumption. 
The primary results show that an unexpected increase in portfolio investment increases UK GDP by 0.4 percentage points after two years. Furthermore, the structural VAR impulse responses illustrate that positive shocks to equity and debt inflow have positive and negative effects on UK GDP, respectively. A one standard deviation shock to equity inflow increases UK GDP by 1.0 percentage point after five years. In contrast, a one standard deviation shock to debt inflow decreases UK GDP by -0.3 percentage points after 20 quarters. Moreover, the FAVAR shows that the effects of shocks to equity and debt inflow on UK GDP are similar to the primary results even after the inclusion of the UK monetary policy factors. Furthermore, UK investment's and consumption's responses to equity and debt inflow shocks are qualitatively similar to UK GDP's responses. However, UK investment's and consumption's responses are larger in magnitude. Finally, a debt inflow shock shows a negative effect on the UK GDP and investment in the postfinancial crisis period while it shows no impact in the pre-financial crisis sample.

The primary contribution of this chapter is to empirically test whether portfolio investment benefits the UK economy. The first chapter finds that shocks to portfolio inflow and its components have positive and significant effects on US GDP in the long-run. Similar to the US case, the estimates show positive long-term effects for portfolio and equity inflow on the UK economy. Contrary to the US case, the debt inflow has no effect on UK GDP in the long term when the prefinancial crisis period is considered. Furthermore, this chapter uses structural VAR models instead of single equation instrumental variable approach commonly used in the literature (i.e. Blanchard et al., 2016; Durham, 2003; and Prasad et al., 2007) and estimates the dynamic effects of capital inflow on UK real economy. This chapter also examines the concern over omitted variable bias by adding the UK monetary policy factor to the core VAR variables using factor augmented VAR models. Our main results hold even after accounting for the impact of UK monetary policy. 
The rest of the chapter is organized as follows: In section 3.2, we present the empirical background on international capital flows. Section 3.3 describes structural VARs and identification strategies used to study dynamic effects of foreign investment and its subcategories on UK GDP. In section 3.4, we describe the data sources used in this study. Section 3.5 presents the chapter's primary results by displaying impulse responses of structural VARs. In section 3.6, we use FAVAR method to include the UK monetary policy factor that captures the common factor of the five UK interest rates. In section 3.7, we present the impulse responses of structural VAR for UK investment and consumption. The study concludes in section 3.8 .

\subsection{Empirical Background on International Capital Flows}

This section discusses multiple aspects of international capital flows. Section 3.2.1 explains different capital flow variables used in the literature. We compare different components of foreign investment in the UK and how they have changed over time in section 3.2.2 Finally, we describe the recent literature about the effect of capital flow on growth in section 3.2.3.

\subsubsection{Capital Flows; Net versus gross}

Different measures of capital inflow have been used in the literature. Current account deficit was the main measurement used in earlier studies. For example, Higgins and Klitgaard (1998) use US current account deficit to measure US capital inflow. They claim that US current account deficit associated with net capital inflow promotes growth in the United States. They pinpoint the benefits of foreign capital inflow, which promote domestic investment despite a decline in private savings. Obstfeld (2012) highlights the relationship between current account imbalances and global financial instability and emphasizes the importance of considering both current account imbalances and gross international financial flows in assessing financial stability risks. 
There are two measurements of capital inflow, net and gross, used in the literature. Ferreira and Laux (2009) and Aizenman et al. (2010), for example, use net capital inflow. Ferreira and Laux (2009) use net portfolio flows and show that openness to portfolio flows have positive effects on economic growth. Aizenman et al. (2010) use net FDI inflows, net portfolio inflows and net bank lending inflows and study the effect of external financing on output volatility in developing countries. They show that higher net portfolio inflows and net bank lending inflows increase the likelihood of experiencing output volatility.

There are also studies that either include both net and gross capital inflows or only focus on gross inflows. Broner et al. (2013) study financial crises and gross capital flows. They compare gross and net capital flow and show that the former is more volatile and pro-cyclical. Forbes and Warnock (2012) differentiate gross capital inflow and outflow in their study and explain that domestic and foreign investors face different exposures to domestic exchange rate and have different access to liquidity, so their response to shocks can be different. In this chapter, we follow recent literature by using gross capital inflow variables.

\subsubsection{UK Capital Flows}

Total foreign investment in the UK reached over $\$ 10$ trillion by the end of the fourth quarter of 2016. The following figures show how foreign investment and its components have changed over time.

Figure 3-1 shows changes in components of foreign investments in the UK over time. There are three facts to observe. Firstly, bank lending inflow is the main component of gross capital inflow in the UK. Bank credit has accounted for almost 50 percent of total foreign investment in the UK between 2010 to 2016 compared to more than 65 percent between 1984 to 2000 . Secondly, unlike the US case, where portfolio investment is the dominant component of gross capital inflow, 
portfolio investment in the UK accounts for less than 35 percent of total foreign investment. Finally, bank credit inflow peaked on the first quarter of 2008 reaching over $\$ 8.5$ trillion before declining. Net foreign investment in the UK had an upward trend before it reached its peak at $\$ 700$ billion in the third quarter of 2014. It has declined ever since, however, and in the fourth quarter of 2016 it was -418 billion dollars, indicating a net capital outflow.

Figure 3-2 illustrates the components of portfolio investment in the UK by plotting debt and equity inflows as percentage of portfolio investment. The debt share declined constantly from 90 percent in 1984 and reached its lowest at 33 percent in the first quarter of 2000. It has gone up ever since reaching 61 percent in the end of fourth quarter of 2016.

Equity and debt are both in the liabilities section of financial accounts. They are, however, very different in nature. Equity measures the value of UK stocks owned by foreigners which can be claimed at any time. Moreover, all stock holders face profits and losses as a result of fluctuations in stock prices and dividends. Debt portion includes debt securities held by central bank, government and deposit taking corporations and their associated interest rates that are due at a given time in the future.

\subsubsection{Capital Flows, Growth and Comparison with This Study}

Blanchard et al. (2016) extend the Mundell Fleming model to study the effect of capital inflow on economic growth. They explain the difference between what theory suggests and what policy makers in emerging economies believe. According to the theory, higher capital inflow into a country with flexible exchange rate policy, puts upward pressure on domestic currency. Currency appreciation deteriorates current account, resulting in lower GDP if the money supply is fixed. Emerging economies' experiences, however, show that an ongoing inflow of foreign capital puts downward pressure on domestic interest rates elevating investment and output. 
There are concerns regarding capital flow. Magud, Reinhart and Rogoff (2011) and De la Torre, Didier and Pienknagura (2012) describe the common fears behind capital controls as fear of currency appreciation, fear of hot money, fear of large inflows, fear of loss of monetary autonomy and fear of instability and uncertainty associated with capital flow movements. Reinhart, Reinhart and Trebesch (2016) study the relationship between global cycles in capital flows, commodity prices and sovereign debt defaults from 1815 to 2015 . They show that both capital inflow and commodity prices reached their lowest point in 1999 and peaked in 2011, which was followed by an acute bust. The "double bust", as authors call it, was associated with a reduction of 2 percentage points in IMF's forecast for 2015 growth in emerging economies. They also find that sovereign default risk increased worldwide at the end of global capital flow surges.

Durham (2003) studies the effect of foreign portfolio investment and bank lending on economic growth by examining 88 countries from 1977 to 2000 . The author shows that one percentage point increases in the ratio of portfolio investments to GDP and foreign bank lending as percentage of GDP reduce average growth rates by 1.4 and 0.2 percentage points, respectively. The author mentions that his results might be affected by simultaneity bias given the use of simultaneous equations. We use structural VAR where each variable is a linear function of lags of itself and lags of all other variables. This method enables us to study the impact of structural shocks to foreign portfolio inflow and its components, equity and debt, on the UK economy.

Prasad et al. (2007) show that nonindustrial countries that relied less on foreign capital have grown faster. They argue that the main reason developing economies struggle to absorb the benefits of foreign capital flow is their underdeveloped financial markets. They suggest that developing countries open their capital market slowly and cautiously by welcoming the type of capital that their economies are capable to absorb while being more vigilant toward less absorbable 
foreign capital. Their estimations show that if current account balance improves by one percentage point, economic growth increases by around 0.1 percentage point.

Additionally, Prasad et al. (2007) claim that developing economies struggle to absorb the benefits of financial liberalization due to their underdeveloped financial infrastructure. That highlights the importance of studying the impact of capital flows on developed countries like the United Kingdom. By looking at the effect of foreign capital on developed economies like the US and the UK, developing countries can project the benefits of financial development against its potential costs and make informed decisions on financial liberalization.

Warnock and Warnock (2009) examine the effect of US government bonds purchased by foreigners on a 10-year Treasury yield. They show that if foreigners did not purchase US government bonds for a year, long-term rates would have been 80 basis points higher. The chapter concentrates on the effect of US government bonds held by foreigners whereas we study the subcategories of foreign investments in the UK. Their dataset only covers the period prior to the recent financial crisis. Our sample, however, includes pre- and post- financial crisis periods.

Ferreira and Laux (2009) look at 50 advanced and less-developed countries from 1988 to 2000 and study the effect of portfolio flows on their growth. They find a positive relationship between openness to portfolio flows and economic growth. They show that the positive effects are greater for less-developed countries. They estimate that advanced and developing countries' GDPs increase by 0.2 and 3.2 percentage points, respectively, in response to a one percent increase in the lagged net sale of local equities by local residents. Their main focus is the effect of net portfolio flows on growth. Our study, however, concentrates on the effect of gross portfolio inflow and its components. Moreover, our sample contains post-financial crises period. 
Aizenman et al. (2013) investigate the impact of international capital flows on economic growth. They study 100 countries between 1990 and 2010 and find a significant and stable relationship between FDI and growth. The relationships between portfolio flows and growth, however, were found to be less stable. They show that the growth rate of GDP per capita increased by 1.8 percent following a one standard deviation increase in FDI inflow. Furthermore, the authors show that one standard deviation increases of FDI inflow, equity investment and short-term debt during pre-crisis period increased GDP per capita growth by $0.9,0.4$ and zero percentage points, respectively.

Blanchard et al. (2015) extend the Mundell Fleming model to study the impact of capital inflow on economic growth. They divide capital inflow into bond flows and non-bond flows and show why there is a difference between what theory suggests and what policymakers believe. Their

estimations illustrate that increases in non-bond flows and bond-flows have expansionary and contractionary effects on output, respectively. To tackle the endogeneity issue, they use instrumental variables. In this study, we use structural VAR models where all variables are assumed to be endogenous.

\subsection{Structural VAR Models}

The relationship between domestic GDP and foreign investment have been studied with causality in both directions. There are studies such as De Vita and Kyaw (2008) that suggest domestic GDP is one of the main determinants of foreign investment in a country. There are also studies similar to Blanchard et al. (2016) that show capital inflow can have a significant impact on domestic economy. Therefore, it is important to consider feedback effects. Thus, we use structural VAR models where all variables are assumed to be endogenous. These models facilitate the study 
of dynamic effects of foreign investment shocks on UK economy. The exogenous shocks in our models are identified so they are independent of each other.

Sims (1980) introduced the Vector Autoregression (VAR) model as a system of linear multivariate regressions where all variables are treated as endogenous and each variable is a function of the lagged values of all other endogenous variables in the system. Our reduced form VAR models are defined as follows:

$Y_{t}=C_{0}+C_{1} Y_{t-1}+C_{2} Y_{t-2}+\cdots+C_{p} Y_{t-p}+e_{t}$

Where $\boldsymbol{Y}_{t}=\left(y_{1 t}, y_{2 t}, \ldots y_{n t}\right)^{\prime}$ is a vector of $n$ variables at time $t, \boldsymbol{C}_{0}$ is a $(n \times 1)$ vector of constants, $\boldsymbol{C}_{1}, \boldsymbol{C}_{2}$ and $\boldsymbol{C}_{p}$ are $(n \times n)$ matrices of coefficients and $\boldsymbol{e}_{t}$ is a $(n \times 1)$ vector of residuals where $E\left[\boldsymbol{e}_{t}\right]=0$ and $E\left[\boldsymbol{e}_{t} \boldsymbol{e}_{\tau}^{\prime}\right]= \begin{cases}\Omega, & \text { if } t=\tau \\ 0 & \text { otherwise }\end{cases}$

We use the growth rate of all variables in our VARs to comply with stationarity requirement. Also, all VAR models include 4 lags which seem to be appropriate for quarterly data. Structural VAR is then defined as follows:

$A_{0} Y_{t}=\alpha+\sum_{i=1}^{4} A_{i} Y_{t-i}+\varepsilon_{t}$

Where $\boldsymbol{Y}_{t}=\left(y_{1 t}, y_{2 t}, \ldots y_{n t}\right)^{\prime}$ is a vector of $n$ variables at time $t$ and $\boldsymbol{\varepsilon}_{t}$ represents the vector of structural innovations that are serially and mutually uncorrelated. If we left multiply the equation (3.2) by $\boldsymbol{A}_{0}^{-1}$, we obtain the reduced form VAR that would have a similar format as equation (3.1). $\boldsymbol{A}_{0}^{-1}$ has a recursive structure which is designed to decompose the reduced form errors $\boldsymbol{e}_{t}$ to exogenous structural shocks $\boldsymbol{\varepsilon}_{t}$.

$e_{t}=A_{0}^{-1} \varepsilon_{t}$

To estimate a structural VAR, we need to start with the reduced-form VAR and solve for structural parameters to find matrix $\boldsymbol{A}_{0}$. 
After identifying the structural VAR, we find impulse responses to each structural shock. This can be achieved by transforming the structural VAR, so each endogenous variable is defined as the sum of associated structural shocks:

$Y_{t}=\mu+\sum_{i=0}^{\infty} \Psi_{i} A^{-1} \varepsilon_{t-i}$

Where $\boldsymbol{\mu}=\boldsymbol{C}(\boldsymbol{L})^{-1} \boldsymbol{C}_{\mathbf{0}}$ and $\boldsymbol{\Psi}_{i}$ represents $(n \times n)$ coefficient matrix of reduced form errors $\boldsymbol{e}_{\boldsymbol{t}}$ in the VMA format. ${ }^{14}$

The recent development in the VAR literature is determining whether the included variables contain sufficient information. Forni and Gambetti (2014) highlight the importance of information sufficiency in structural VAR models. They introduce two tests that can examine any structural VAR and whether they contain sufficient information to provide meaningful results for all the structural shocks. They assume that there is a state space that represents the economy, and they suggest estimating the state variables by applying principal components method on a large number of macroeconomic variables. The authors' second step is to test whether the principal components Granger cause the VAR variables, and, only if the Granger causality hypothesis is not rejected, the VAR variables contain sufficient information. Testing the information sufficiency of the VAR variables will be used for the following research.

For each model we first explain $\boldsymbol{Y}_{t}$, the variables included, and then show the recursive structure used to decompose the reduced form errors.

\subsubsection{Model 1: UK GDP and Net Capital Inflow}

This model studies the effect of net foreign investment in the UK on UK GDP. UK GDP is UK GDP growth and net capital inflow is the growth of net foreign investment in the UK. Net

${ }^{14} \boldsymbol{C}(\boldsymbol{L})$ is defined as $\boldsymbol{C}(\boldsymbol{L})=\left(\boldsymbol{I}_{n}-\boldsymbol{C}_{1} \boldsymbol{L}-\boldsymbol{C}_{2} \boldsymbol{L}^{2}-\cdots-\boldsymbol{C}_{p} \boldsymbol{L}^{p}\right)$ where $\boldsymbol{L}, \boldsymbol{L}^{2}, \ldots, \boldsymbol{L}^{p}$ are lag operators 
foreign investment in the UK equals the gross UK assets held by foreigners less the gross foreign assets held by UK residents. Our structural VAR follows equation (3.2) and the decomposition of reduced form errors $\boldsymbol{e}_{t}$ follows equation (3.3):

$$
\boldsymbol{e}_{t} \equiv\left(\begin{array}{c}
e_{t}^{U K G D P} \\
e_{t}^{\text {net capital inflow }}
\end{array}\right)=\left[\begin{array}{ll}
a_{11} & 0 \\
a_{21} & a_{22}
\end{array}\right]\left(\begin{array}{c}
\varepsilon_{t}^{U K} \text { GDP shock } \\
\varepsilon_{t}^{\text {net capital inflow shock }}
\end{array}\right)
$$

We assume that UK GDP growth only responds to net capital inflow innovations with a lag. The effect of capital inflow on domestic output derives from two channels: exchange rate and interest rate. Exchange rate channel concentrates on the effect of higher capital inflow on the demand for local currency, which creates an upward pressure on British Pound (GBP) in our case. Appreciation of GBP means British goods and services are more expensive abroad while foreign goods and services become cheaper in the UK. Thus, UK balance of payment deteriorates causing UK output to decline.

The interest rate channel explains that the flow of foreign capital into the UK increases the demand for the UK assets, which creates a downward pressure on domestic interest rates. Reduced domestic interest rates lower the cost of borrowing in the UK and promote investment and output. These effects will not be instant. Thus, we assume that changes in capital inflow will not affect UK GDP contemporaneously. Net capital inflow innovations not explained by UK GDP shocks will be included on net capital inflow shocks. The assumption that UK output does not respond to capital flow innovations contemporaneously holds throughout this chapter.

\subsubsection{Model 2: UK GDP, Foreign Direct Investment (FDI) in the UK, UK Portfolio Assets Held} by Foreigners and Foreign Bank Lending.

In this model, we study how components of UK assets held by foreign investors affect UK GDP. FDI inflow measures FDI growth, portfolio inflow equals the growth of portfolio investments held by foreigners and bank credit inflow measures the growth of foreign bank lending. 
The setup of the structural VAR is the same as equation (3.2) and $\boldsymbol{e}_{t}$ follows equation (3.3):

$$
\boldsymbol{e}_{t} \equiv\left(\begin{array}{c}
e_{t}^{U K G D P} \\
e_{t}^{\text {fdi inflow }} \\
e_{t}^{\text {portfolio inflow }} \\
e_{t}^{\text {bank credit inflow }}
\end{array}\right)=\left[\begin{array}{llll}
a_{11} & 0 & 0 & 0 \\
a_{21} & a_{22} & 0 & 0 \\
a_{31} & a_{32} & a_{33} & a_{34} \\
a_{41} & a_{42} & a_{43} & a_{44}
\end{array}\right]\left(\begin{array}{c}
\varepsilon_{t}^{U K} \text { GDP shock } \\
\varepsilon_{t}^{\text {fdi inflow shock }} \\
\varepsilon_{t}^{\text {portfolio inflow shock }} \\
\varepsilon_{t}^{\text {bank credit inflow shock }}
\end{array}\right)
$$

UK GDP growth does not respond to capital inflow innovations, including FDI, portfolio and bank credit innovations, within the same quarter. We assume that they only affect UK GDP growth with a lag. We also assume FDI inflow does not respond to portfolio innovations and bank credit innovations within the same period. This assumption is in line with reality since FDI is considered as a long-term investment with minimal fluctuations in response to temporary changes. Therefore, we assume any portfolio or bank credit innovations only affect FDI with a lag.

However, fairly liquid portions of capital inflow, portfolio investments and bank credits, are more responsive to shocks. Thus, we allow the portfolio and bank credit inflow to respond to each other's innovations contemporaneously. This assumption means $a_{34}=a_{43}$ which means portfolio and bank credit inflows respond to each other's shocks contemporaneously and with equal magnitudes.

\subsubsection{Model 3: UK GDP, UK Equity Portfolio and UK Debt Portfolio Held by Foreigners}

In this model, we focus on the effects of shocks to equity and debt inflow on UK GDP. Equity inflow measures the growth rate of UK equity and investment fund shares held by foreign investors and debt inflow is the growth rate of UK debt held by foreign investors. Equity and investment fund shares and debt securities are held by the central bank, deposit-taking corporations, general government and other sectors including financial corporations. The structural VAR follows equation (3.2) where $\boldsymbol{e}_{t}$ has the following format: 


$$
\boldsymbol{e}_{t} \equiv\left(\begin{array}{c}
e_{t}^{U K} G D P \\
e_{t}^{\text {equity inflow }} \\
e_{t}^{\text {debt inflow }}
\end{array}\right)=\left[\begin{array}{lll}
a_{11} & 0 & 0 \\
a_{21} & a_{22} & a_{23} \\
a_{31} & a_{32} & a_{33}
\end{array}\right]\left(\begin{array}{c}
\varepsilon_{t}^{U K} \text { GDP shock } \\
\varepsilon_{t}^{\text {equity inflow shock }} \\
\varepsilon_{t}^{\text {debt inflow shock }}
\end{array}\right)
$$

We assume that UK GDP does not respond to equity inflow or debt inflow innovations contemporaneously. We allow debt and equity inflow to respond to each other's innovations contemporaneously by assuming $a_{23}=a_{32}$. The equity and bond markets operate on a daily basis and investors have access to daily information such as interest rates, yields and prices. Therefore, our assumption is in line with reality, where investors can observe unexpected changes and respond to them swiftly.

\subsection{Data}

The data source used for this chapter is IMF, Balance of Payments and International Investment Position Statistics (BOP/IIP) for the United Kingdom. This source provides quarterly data on the levels of various UK assets held by foreigners and foreign assets held by UK residents at the end of each quarter. This source contains the main categories of foreign investments, foreign direct investment, foreign portfolio investment and bank credit, as well as their components, equity and debt. That allows us to study the effect of foreign portfolio investment and its components, equity and debt, on the UK real GDP.

In addition to foreign investment variables, we collect UK nominal GDP, UK total consumption, UK fixed capital formation, UK CPI and Sterling exchange rate against US dollar from Office for National Statistics. All variables are corrected for inflation. Foreign investment variables that are reported in US dollars have been converted to British Pound before being corrected for inflation. All variables have unit roots so to comply with stationarity condition of 
VAR models, we use their stationary growth rates. ${ }^{15}$ Descriptive statistics of all variables are presented in Table 3-1.

\subsection{Primary Empirical Results}

This section presents impulse responses for each structural VAR model introduced in section 3.3. We only report the accumulated responses as they represent the long-term effects on UK GDP. The first row of each panel presents the effect of capital flow variables on UK GDP. All variables entering our models are in growth rate format, so the unit of each vertical axis is percentage point. We report our results for two sets of samples. Panel A includes the full sample from 1984 Q1 to 2016 Q1 and Panel B contains a sub-sample from 1993 Q1 to 2016 Q1. The shorter sample covers the post- Exchange Rate Mechanism (ERM) when the British Pound exchange rate began to float.

British government left ERM on September 16, 1992 following two failed attempts, on the same day, to maintain the Pound Sterling's parity by increasing the base interest rate to $15 \%{ }^{16}$ Söderlind (2000) shows how market expectations changed in response to the events before and after UK left ERM. He highlights the fact that events leading to September 16, 1992 created an expectation of high interest rates in the market. The author's estimations illustrate that the introduction of inflation targeting in October 1992 reduced both uncertainty and long-term interest rates. He shows that the UK chancellor's speech on November 12, 1992 clarified the future of UK monetary policy and narrowed the distribution of future UK interest rates.

\footnotetext{
${ }^{15}$ Unit root test results for all variables are reported Appendix 4

${ }^{16}$ For more information on the events that led to British Pound leaving ERM, please visit Bank of England's website: https://www.bankofengland.co.uk/-/media/boe/files/quarterly-bulletin/1992/operation-of-monetarypolicy-qb-1992-q4.pdf
} 
Figure 3-3 displays impulse responses of the first model that studies the effect of net foreign investment in the UK on UK GDP. Panel A shows that a positive one standard deviation shock to net capital inflow has a negative effect of -0.2 percentage points on the UK GDP in the long-run. The effect of net capital inflow on UK GDP becomes positive when we consider 1993 Q1 to 2016 Q1 sample. Panel B illustrates that a one standard deviation shock to net capital inflow increases UK GDP by 0.1 percentage points after two years. The negative impacts shown in panel A might be the results of events prior to leaving the ERM. Both effects are statistically insignificant, however.

Figure 3-4 displays responses of the second model and illustrates UK GDP responses to shocks to FDI, portfolio and bank credit inflows. Impulse responses from both samples show that a positive shock to portfolio inflow has a positive effect on UK output. A one standard deviation increase in portfolio inflow raises UK GDP by 0.4 percentage points after eight quarters. A positive shock to bank credit inflow has a negative effect of -0.2 percentage points on UK GDP after two years when the full sample is considered. The negative effect becomes slightly larger in the shorter sample shown in panel B. Our results are in line with Durham (2003)'s, where foreign bank lending showed to have a negative effect on growth.

Figure 3-5 portrays impulse responses of UK GDP to equity and debt inflow shocks as described in the third SVAR. A positive shock to equity inflow has a positive effect on UK output. Our full sample analysis shows that a one standard deviation shock to portfolio equity inflow increases UK GDP by 0.7 percentage points after eight quarters. The effect of equity inflow shock on UK GDP in our shorter sample remains positive but shrinks in magnitude. We find that a positive shock to debt inflow has a negative impact on UK output in the long-run when we consider the full sample. Panel B shows that the effect of debt inflow on UK GDP becomes zero when we 
consider the shorter sample. Furthermore, panel C illustrates that a debt inflow shock has no impact on UK GDP when the pre-financial crisis period of 1984Q1- 2007Q4 is considered. Our findings are in line with Blanchard et al. (2015)'s estimations. They show that one percent increase of portfolio equity flows as percentage of GDP increases GDP growth by 0.5 percentage points. They also show that debt inflow has a negative impact on growth.

\subsection{Results from Factor Augmented VAR Models}

One of the limitations of VAR approach is that adding new variables to the model increases the number of parameters that need to be estimated exponentially. Therefore, we follow the conventional method and start with a core VAR and change the variables to study their effects. As a result, there might be concerns that our estimates are subjected to omitted variable bias. For example, one possible question can be whether the inclusion of interest rates, representing UK monetary policy, change our results. This section uses a Factor Augmented VAR (FAVAR) method, similar to the framework used by Bernanke et al. (2005), to include the effects of UK monetary policy.

UK monetary policy has changed significantly during our sample period. Prior to joining ERM, Britain had an informal exchange rate target against Deutsche Mark. In October 1990 UK officially joined ERM and introduced explicit exchange rate targets against other European currencies. Two years later on September 16, 1992, it left ERM as a result of a widespread speculative attack on British Pound. UK government's attempt to maintain Pound parity by increasing short term interest rates to $15 \%$ failed, and Britain was forced to leave ERM and allow its currency to float.

On October 1992, a new monetary policy with two main components were announced: first, interest rates would be set to achieve price stability, an inflation rate within the band of 1 to 
4\%. Second, the Bank of England was given greater roles in setting interest rates. Those institutional changes increased the transparency and openness of UK monetary policymaking (King, 1997). The Bank of England became independent in May 1997 and the Monetary Policy Committee (MPC) became responsible for setting interest rates. It is the responsibility of UK government to set the monetary policy by designing the inflation target. Then, it is MPC's responsibility to set interest rates to achieve this inflation target. As a result of these policies, the UK inflation rate has remained low. ${ }^{17}$

The FAVAR model follows the assumption that UK GDP is an observable slow-moving factor, capital inflow variables are observable fast-moving factors and there is one unobservable fast-moving factor representing UK monetary policy that is estimated from five UK interest rate series. Observable factors are standardized versions of the associated observable variables and the unobservable factor is estimated using principal components method as explained by Bernanke et al. (2005).

The FAVAR impulse responses are comparable to VAR impulse responses associated with the model (3) as we assume that our core VAR variables are observable. In contrast to the VAR impulse responses, the vertical axes in the FAVAR impulse responses represent unit of standard deviation as all included factors are standardized. We only show impulse responses of UK GDP to unexpected changes in our variables of interest, equity and debt inflow. Thus, to compare the magnitude of FAVAR results with SVAR's, we need to multiply the FAVAR responses by one standard deviation of UK GDP, 1.1 percentage points.

${ }^{17}$ For more information on how UK monetary policy has changed since 1992, please see Angeriz and Arestis (2007) 
The FAVAR investigates the effects of shocks to equity and debt inflow on UK GDP. Following factors are included:

$\boldsymbol{Y}_{t}=\left(U K G D P_{t}, \text { equity inflow }{ }_{t}, \text { debt inflow }{ }_{t}, \text { monetary policy }_{t}\right)^{\prime}$

UK GDP does not respond to equity, debt and monetary policy innovations within the same quarter. Equity and debt inflow respond to each other innovations contemporaneously and in equal magnitudes. Following Bernanke et al. (2005) we order the monetary policy factor last so interest rate innovations that have not been captured by UK GDP, equity and debt shocks are defined by UK monetary policy shocks. The interest rates used to calculate the UK monetary policy factor are 1 month mean interbank lending rate, 3 month mean interbank lending rate, 3 month Treasury bills, 6 month mean interbank lending rate and 1 year mean interbank lending rate.

Figure 3-6 shows the effect of equity and debt inflow shocks on UK GDP. A positive one standard deviation shock to equity inflow increase UK GDP by 0.7 percentage points after two years. Moreover, a positive shock to debt inflow decreases UK GDP by -0.2 percentage points after eight quarters. When we consider the smaller sample, the effect of debt inflow on UK GDP becomes zero and the positive effect of equity inflow on UK GDP shrinks in magnitude.

\subsection{Effect of Equity and Debt Inflows on GDP Components}

This section studies the effects of equity and debt inflows on the UK's GDP components, consumption and investment. UK investment and consumption datasets were collected from UK Economic Accounts: main aggregates. Investment accounts for gross fixed capital formation in British Pound at current prices. Consumption includes final consumption of households and nonprofit institutions serving households in British Pound at current prices. It, however, excludes general government consumption. 
Similar to UK GDP, investment and consumption are corrected for inflation using UK CPI. This section uses the structural VAR model introduced in section 3.3.3. Similar to the primary results, both sections include three sets of results for the full sample, 1984 Q1-2016Q1, shown in panel A and shorter sample, 1993Q1-2016Q1, illustrated in panel B as well as Panel C that contains the sample 1984Q1-2008Q1 for the UK investment and sample 2009Q1-2016Q4 for the consumption case.

Figure 3-7 shows UK investment impulse responses to equity and debt inflow shocks. An unexpected increase in equity and debt inflows have positive and negative effects on UK investment, respectively. Panel A illustrates that a one standard deviation shock to equity inflow increases UK investment by 1.9 percentage points after two years. It also shows that a one standard deviation shock to debt inflow decreases UK investment by -0.1 percentage points after two years. Panel B shows that UK investment increases by 1.3 percentage points eight quarters after a positive shock to equity inflow. It also displays that a positive one standard deviation shock to debt inflow decreases UK investment by -0.6 percentage points after two years. Finally, Panel C shows that a debt inflow shock has a positive effect on UK investment in the short-run and zero effect in the long-run when the pre-financial crisis period of 1984Q-2008Q1 is considered.

Figure 3-8 displays impulse responses of UK consumption to unexpected increases in equity and debt inflow. Panel A shows that a positive shock to equity inflow increases UK consumption by 0.9 percentage points after two years. It also shows that a one standard deviation shock to debt inflow decreases UK consumption by -0.6 percentage points after eight quarters. Panel B illustrates that a positive one standard deviation shock to equity inflow increase UK consumption by 0.7 percentage points after two years. The panel also displays that an unexpected increase in debt inflow decreases UK consumption by -0.2 percentage points after eight quarters. 
Panel C displays that a positive shock to debt inflow has no impact on UK consumption in the long-run when we restrict the sample to post-financial crisis period of 2009Q1-2016Q4.

The Euro was officially introduced on January 1, 2002, and 12 countries adopted it as their legal tender. In order to study the effect of adaptation of the Euro we divide our sample to pre- and post- Euro period and repeat our study. The results are qualitatively similar to our full sample results presented above.

\subsection{Conclusion}

The first chapter finds that positive shocks to capital inflow have expansionary effects on the US economy. It suggests that developing countries can expect similar positive effects in the long-run by opening their financial markets. However, an important question arises. Is the positive effect of foreign investment specific to the United States or do other developed countries also benefit from these positive effects? This chapter aims to answer that question by looking at the United Kingdom.

We use quarterly data on the UK's foreign investment positions that are available from IMF Balance of Payments and International Investment Position Statistics (BOP/IIP). We use structural VAR to study the dynamic effect of capital inflow on the UK's GDP by incorporating feedback effects in the models.

The results show that a one standard deviation shock to portfolio inflow increases UK GDP by 0.4 percentage points after two years. Equity inflow is the main force behind that positive effect. Unlike the US case, debt inflow shocks have contractionary effects on UK GDP in the long-run. Our estimations on the impacts of equity and debt on UK GDP are similar to the results of Blanchard et al. (2015). They estimate that one percent increases of portfolio equity inflow and 
debt inflow increase emerging economies GDP growth by 0.4 and -0.03 percentage points, respectively.

The effect of equity and debt inflow shocks on UK GDP remains positive and negative, respectively, even after we control for the effects of UK monetary policy. Furthermore, we study the impacts of shocks to equity and debt inflow on components of UK GDP, consumption and investment. We find that a one standard deviation shock to equity inflow increases both UK consumption and investment. A debt inflow shock shows a negative effect on the UK GDP and investment in the post-financial crisis period while it shows no impact in the pre-financial crisis sample.

The results can be helpful to policy makers in emerging countries by providing evidence of the benefit to developing their capital markets, especially stock markets. Whereas the positive effects of debt inflow might be unique to the US, the expansionary impacts of equity inflow have been shown in this chapter as well as other studies like Blanchard et al. (2016), Aizenman et al. (2013). By studying the impact of equity inflow on the advanced economies, emerging economies can project the effect of foreign investment on their own growth once their financial markets are fully developed. 


\subsection{References}

Aizenman, J., Chinn, M. D., \& Ito, H. (2010). The emerging global financial architecture: Tracing and evaluating new patterns of the trilemma configuration. Journal of International Money and Finance, 29(4), 615-641.

Aizenman, J., Jinjarak, Y., \& Park, D. (2013). Capital Flows and Economic Growth in the Era of Financial Integration and Crisis, 1990-2010. Open Economies Review, 24(3), 371-396.

Angeriz, A., \& Arestis, P. (2007). Monetary policy in the UK. Cambridge Journal of Economics, $31,863-884$.

Bank of England. (1992, November). Bank of England Quarterly Bulletin: November 1992. Retrieved from Bank of England: https://www.bankofengland.co.uk//media/boe/files/quarterly-bulletin/1992/operation-of-monetary-policy-qb-1992-q4.pdf

Bernanke, B. S., Boivin, J., \& Eliasz, P. (2005). Measuring the Effects of Monetary Policy: A Factor-Augmented Vector Autoregressive (FAVAR) Approach. The Quarterly Journal of Economics, 120(1), 387-422.

Blanchard, O., Ostry, J. D., Ghosh, A. R., \& Chamon, M. (2015). Are Capital Inflows Expansionary or Contractionary? Theory, Policy Implications, and Some Evidence. NBER Working Paper No. 21619.

Blanchard, O., Ostry, J. D., Ghosh, A. R., \& Chamon, M. (2016). Capital Flows: Expansionary or Contractionary? American Economic Review: Papers and Proceedings, 565-569.

Broner, F., Didier, T., Erce, A., \& Schmukler, S. L. (2013). Gross capital flows: Dynamics and crises. Journal of Monetary Economics, 60(1), 113-133. 
De la Torre, A., Didier, T., \& Pienknagura, S. (2012). Latin America Copes with Volatility: The Dark Side of Globalization. World Bank Latin America and Caribbean Semi-Annual Report.

De Vita, G., \& Kyaw, K. S. (2008). Determinants of Capital Flows to Developing Countries: a Structural VAR Analysis. Journal of Economic Studies, 35(4), 304-322.

Durham, J. B. (2003, February). Foreign Portfolio Investment, Foreign Bank Lending, and Economic Growth. Board of Governors of the Federal Reserve System International Finance Discussion Papers No.757.

Ferreira, M. A., \& Laux, P. A. (2009). Portfolio flows, volatility and growth. Journal of International Money and Finance(28), 271-292.

Forbes, K. J., \& Warnock, F. E. (2012). Capital flow waves: Surges, stops, flight, and retrenchment. Journal of International Economics, 88(2), 235-251.

Forni, M., \& Gambetti, L. (2014). Sufficient information in structural VARs. Journal of Monetary Economics, 66, 124-136.

Higgins, M., \& Klitgaard, T. (1998). Viewing the US Current Account Deficit as a Capital Inflow. Current Issues in Economics and Finance, 4(13).

King, M. (1997). Changes in UK monetary policy: Rules and discretion in practice. Journal of Monetary Economics, 39, 81-97.

Magud, N. E., Reinhart, C., \& Rogoff, K. (2011). Capital Controls: Myth and Reality - A Portfolio Balance Approach. NBER Working Papers 16805.

Obstfeld, M. (2012). Does the Current Account Still Matter? American Economic Review, 102(3), 1-23. 
Prasad, E. S., Rajan, R. G., \& Subramanian, A. (2007). Foreign Capital and Economic Growth. Brookings Papers on Economic Activity, 1, 153-230.

Reinhart, C. M., Reinhart, V., \& Trebesch, C. (2016). Global Cycles: Capital Flows, Commodities, and Sovereign Defaults, 1815-2015. American Economic Review: Papers \& Proceedings, $106(5), 574-580$.

Söderlind, P. (2000). Market Expectations in the UK Before and After the ERM Crisis. Economica, $67(265), 1-18$

Sims, C. A. (1980). Macroeconomics and Reality. Econometrica, 48(1), 1-48.

Warnock, F. E., \& Warnock, V. C. (2009). International capital flows and US interest rates. Journal of International Money and Finance, 28, 903-919. 
Table 3-1: Descriptive Statistics of the variables

\begin{tabular}{|c|c|c|c|c|c|c|c|}
\hline Variables & Mean & Maximum & Minimum & Std. Dev. & Source & Sample & \# Obs. \\
\hline Real GDP growth & 0.60 & 3.76 & -3.33 & 1.10 & $\mathrm{ONS}^{1}$ & 1984 Q1-2016 Q1 & 128 \\
\hline Real investment growth & 0.48 & 9.56 & -8.59 & 3.20 & $\mathrm{ONS}^{1}$ & 1984 Q1-2016 Q1 & 128 \\
\hline Real consumption growth & 0.64 & 3.22 & -2.85 & 0.99 & $\mathrm{ONS}^{1}$ & 1984 Q1-2016 Q1 & 128 \\
\hline Real net capital inflow growth & 17.86 & 2026.57 & -1877.00 & 419.46 & $\mathrm{IMF}^{2}$ & 1984 Q1-2016 Q1 & 128 \\
\hline Real total capital inflow growth & 1.51 & 12.65 & -14.83 & 4.16 & $\mathrm{IMF}^{2}$ & 1984 Q1-2016 Q1 & 128 \\
\hline Real total capital outflow growth & 1.42 & 11.91 & -15.55 & 4.38 & $\mathrm{IMF}^{2}$ & 1984 Q1-2016 Q1 & 128 \\
\hline Real FDI inflow growth & 2.01 & 30.02 & -14.25 & 6.03 & $\mathrm{IMF}^{2}$ & 1984 Q1-2016 Q1 & 128 \\
\hline Real portfolio inflow growth & 2.07 & 15.50 & -18.13 & 5.78 & $\mathrm{IMF}^{2}$ & 1984 Q1-2016 Q1 & 128 \\
\hline Real bank credit inflow growth & 1.15 & 12.14 & -14.59 & 4.74 & $\mathrm{IMF}^{2}$ & 1984 Q1-2016 Q1 & 128 \\
\hline Real portfolio equity inflow growth & 3.10 & 30.15 & -25.25 & 9.86 & $\mathrm{IMF}^{2}$ & 1984 Q1-2016 Q1 & 128 \\
\hline Real portfolio debt inflow growth & 1.75 & 14.80 & -19.69 & 5.04 & $\mathrm{IMF}^{2}$ & $1984 \mathrm{Q} 1-2016 \mathrm{Q} 1$ & 128 \\
\hline 1 month interbank lending rate & 5.88 & 15.06 & 0.31 & 4.14 & $\mathrm{BOE}^{3}$ & 1984 Q1-2016 Q1 & 128 \\
\hline 3 month interbank lending rate & 5.96 & 15.19 & 0.38 & 4.09 & $\mathrm{BOE}^{3}$ & 1984 Q1-2016 Q1 & 128 \\
\hline 3 month Treasury bills & 5.55 & 14.52 & 0.12 & 3.97 & $\mathrm{BOE}^{3}$ & 1984 Q1-2016 Q1 & 128 \\
\hline 6 month interbank lending rate & 6.03 & 15.24 & 0.56 & 3.99 & $\mathrm{BOE}^{3}$ & 1984 Q1-2016 Q1 & 128 \\
\hline 1 year interbank lending rate & 6.17 & 15.25 & 0.78 & 3.84 & $\mathrm{BOE}^{3}$ & 1984 Q1-2016 Q1 & 128 \\
\hline
\end{tabular}

${ }^{1}$ The Office for National Statistics

${ }^{2}$ International Monetary Fund, Balance of Payments and International Position Statistics (BOP/IIP)

${ }^{3}$ Bank of England, interest and exchange rates data 
Figure 3-1-Components of foreign investments in the UK

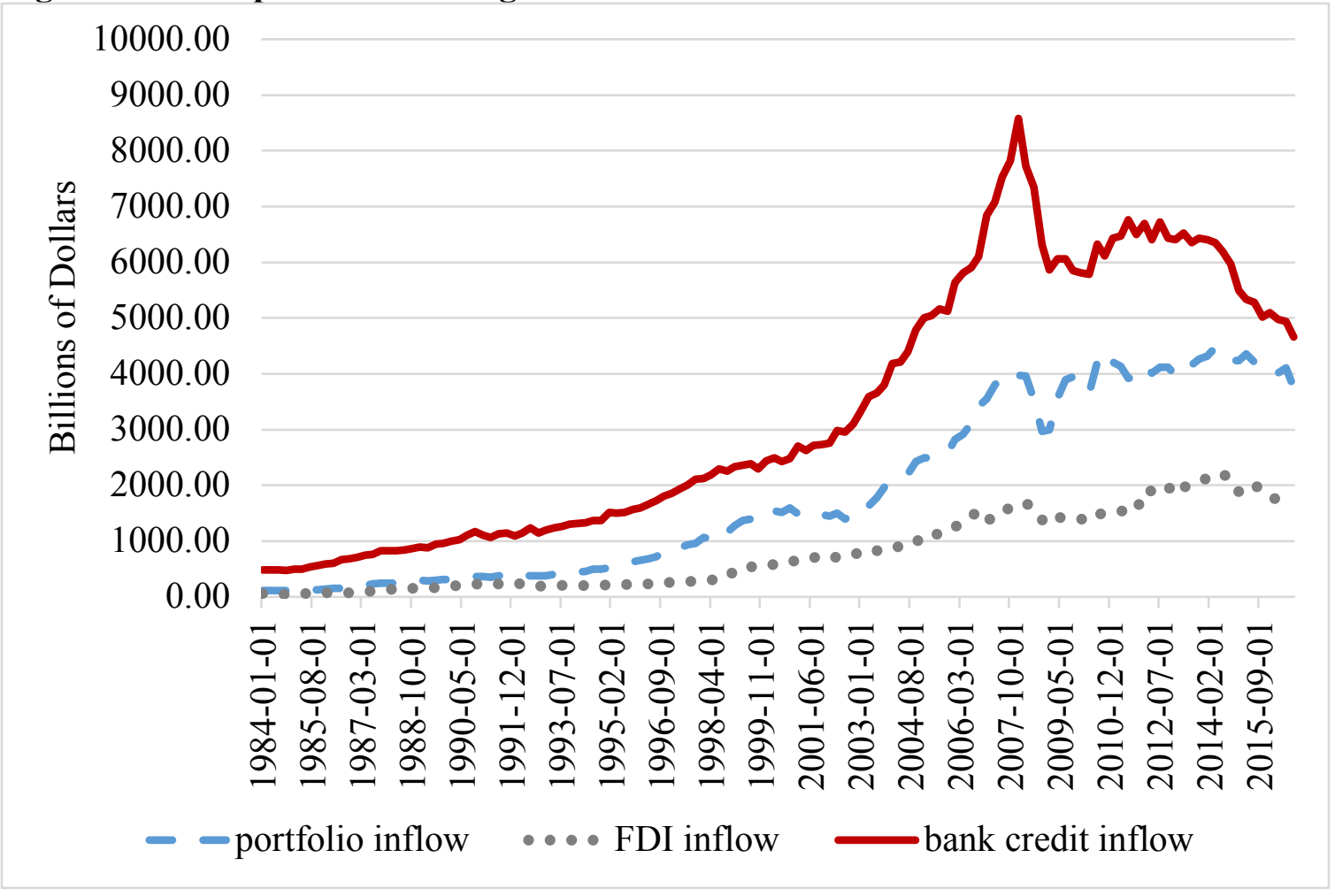

Source: IMF, Balance of Payments and International Investment Position Statistics (BOP/IIP) for the United Kingdom 
Figure 3-2-Debt and equity as share of portfolio investment

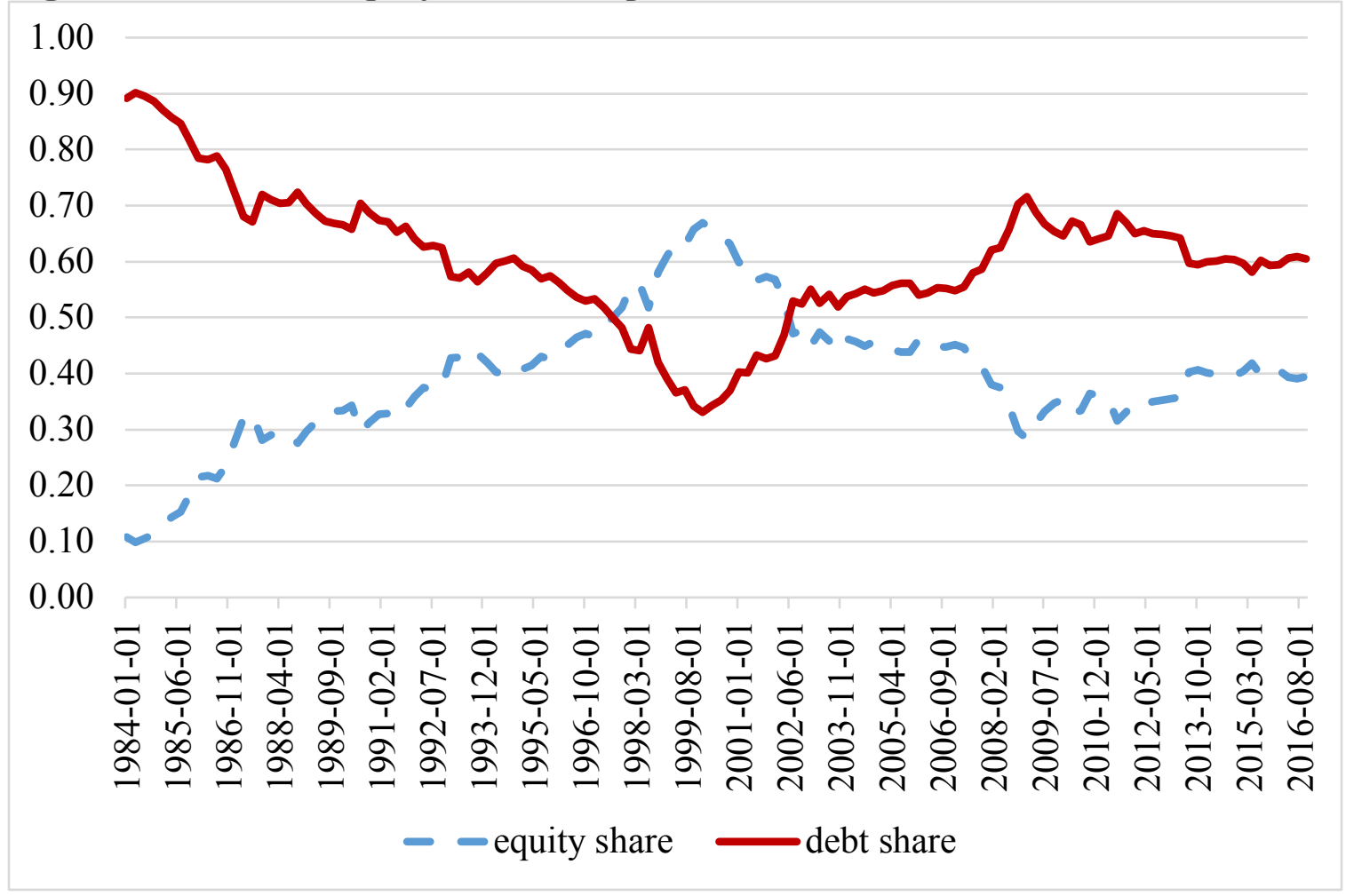

Source: IMF, Balance of Payments and International Investment Position Statistics (BOP/IIP) for the United Kingdom 
Figure 3-3-Impulse responses for net foreign investment and UK GDP

Panel A: Sample period 1984 Q1 - 2016 Q1

Accumulated Response to Structural VAR Innovations \pm 2 S.E.

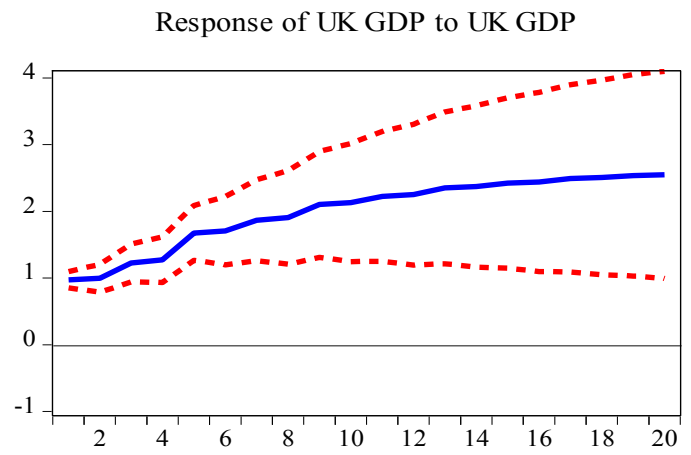

Response of UK GDP to net capital inflow shock

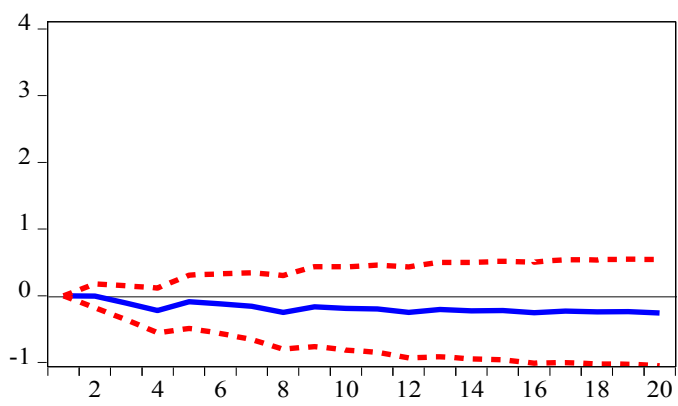

Response of net capital inflow to UK GDP shock

Response of net capital inflow to net capital inflow shock
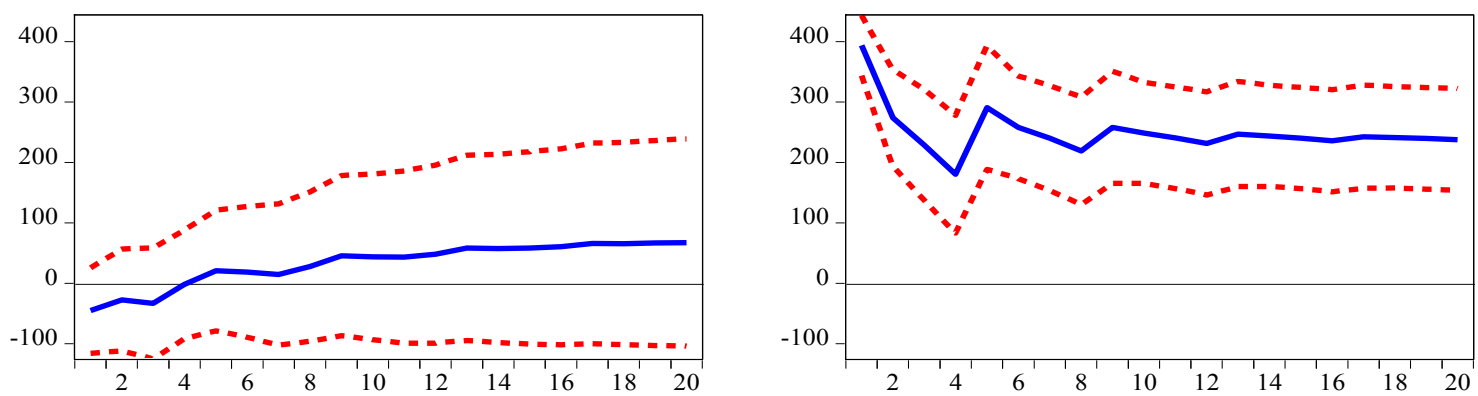
Panel B: Sample period 1993 Q1 - 2016Q 1

Accumulated Response to Structural VAR Innovations \pm 2 S.E.

Response of UK GDP to UK GDP shock

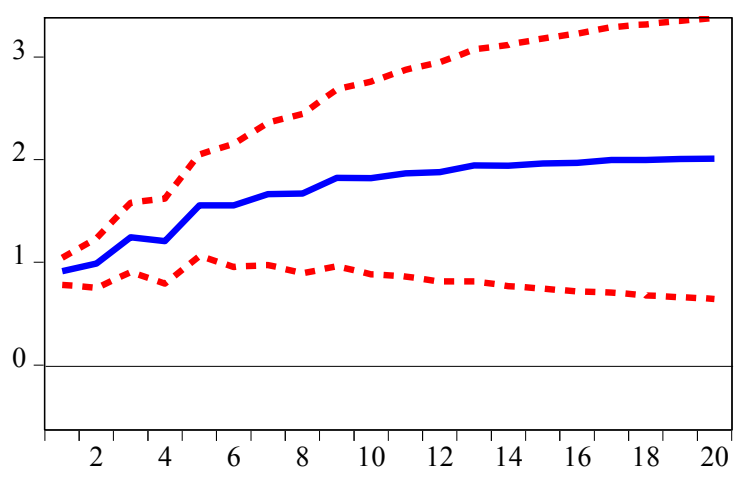

Response of net capital inflow to UK GDP shock

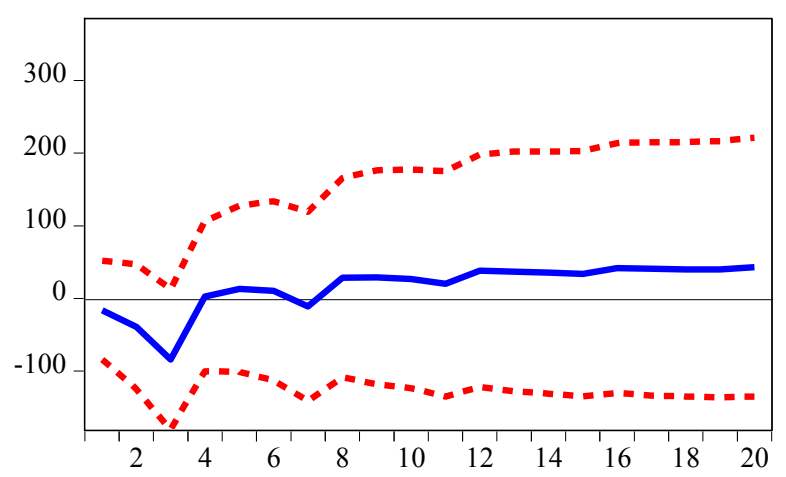

Response of UK GDP to net capital inflow shock

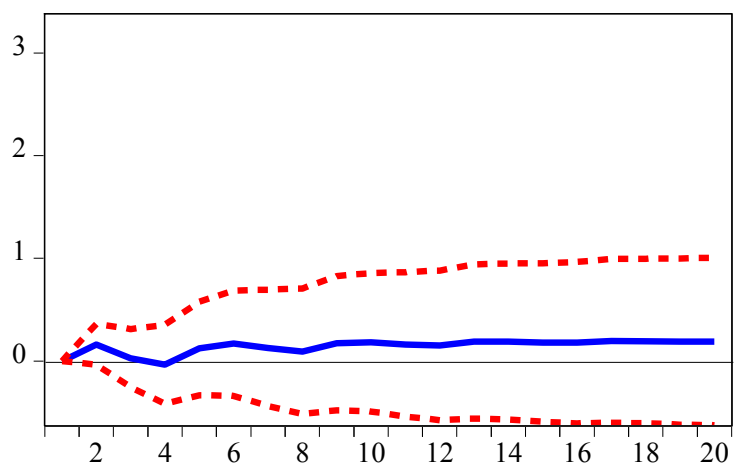

Response of net capital inflow to net capital inflow shock

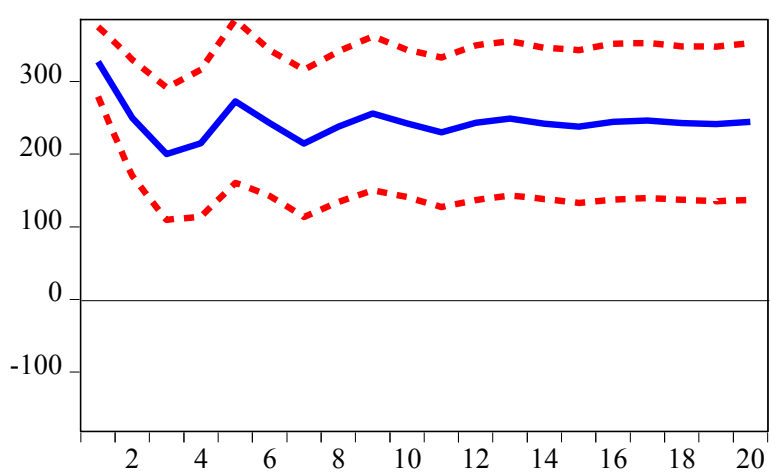


Figure 3-4-Impulse responses for FDI, portfolio inflow, bank credit and UK GDP Panel A: Sample period 1984 Q1 - 2016 Q1

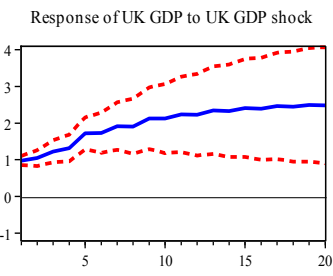

Response of FDI in flow to UK GDP shock

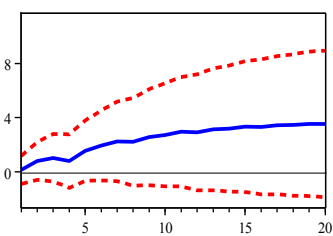

Response of portfolio inflow to UK GDP shock

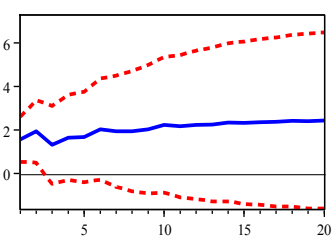

Response of bank credit inflow to UK GDP shock

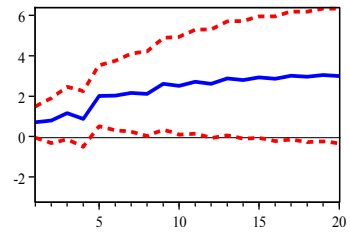

Accumulated Response to Structural VAR Innovations \pm 2 S.E.

Response of UK GDP to FDI inflow shock

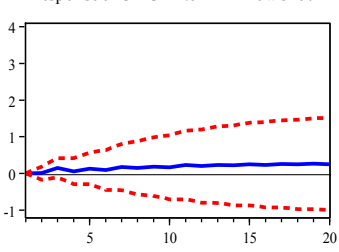

Response of FDI inflow to FDI inflow shock

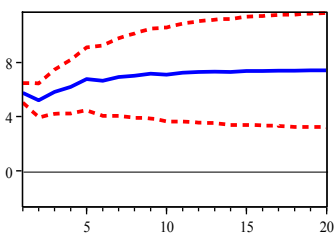

Response of portfolio inflow to FDI inflow shock

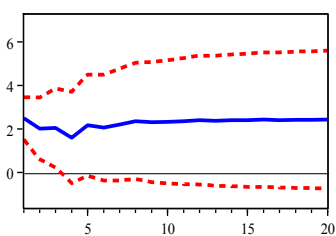

Response of bank credit inflow to FDI inflow shock

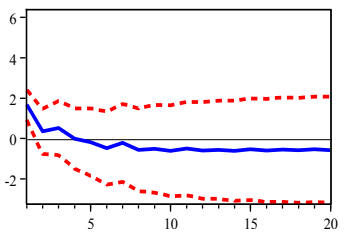

Response of UK GDP to portfolio inflow shock

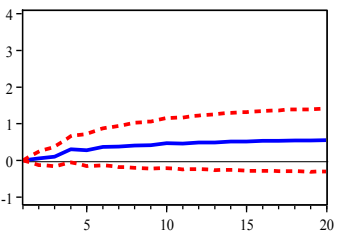

Response of FDI inflow to portfolio inflow shock

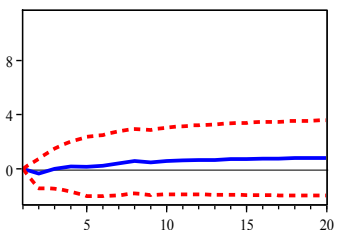

Response of portfolio inflow to portfolio inflow shock

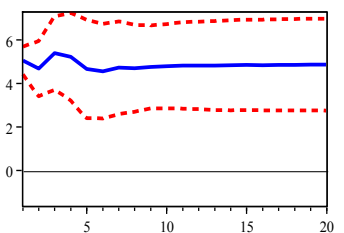

Response of bank credit inflow to portfolio inflow shock

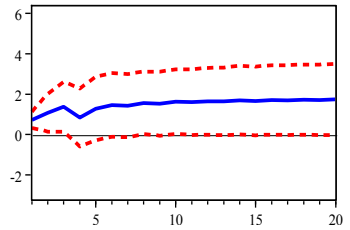

Response ofUK GDP to bank credit in flow shock

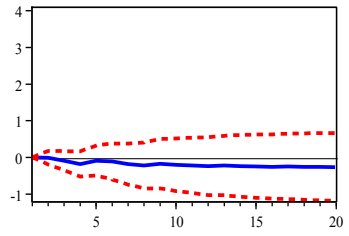

Response of FDI inflow to bank credit inflow shock

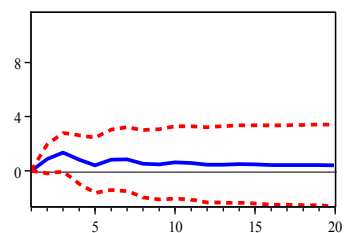

Response of portfolio inflow to bank credit inflow shock

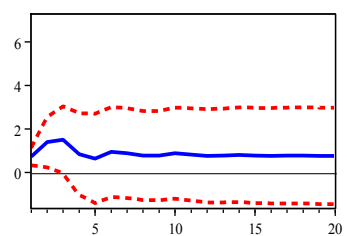

Response of bank credit inflow to bank credit inflow shock

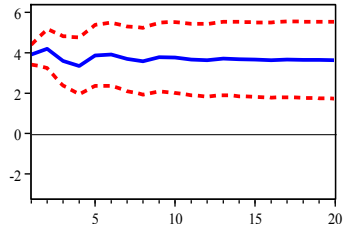




\section{Panel B: Sample period 1993 Q1 - 2016 Q1}

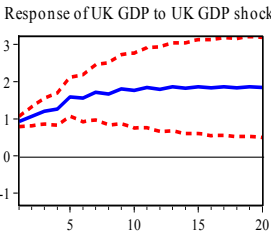

Response of FDI in flow to UK GDP shock

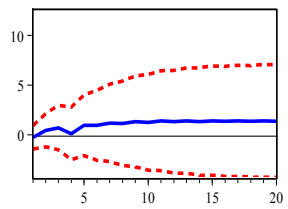

Response of portfolio in flow to UK GDP shock

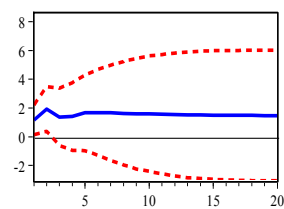

Response of bank credit in flow to UK GDP shock

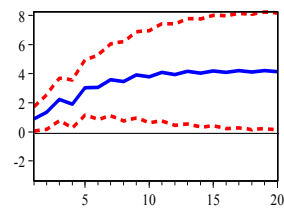

Accumulated Response to Structural VAR Innovations \pm 2 S.E.
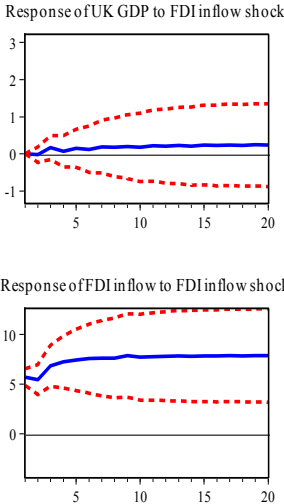

Response of portfolio inflow to FDI in flow shock

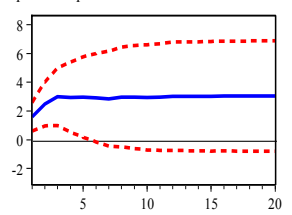

Response of bank credit in flow to FDI in flow shock

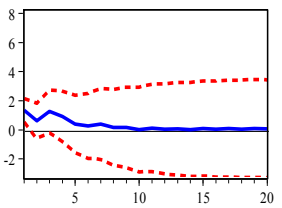

Response of UK GDP to portfolio inflow shock

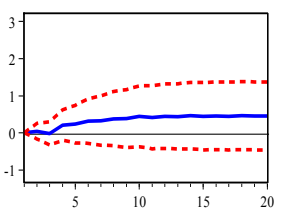

Response ofFDI in flow to portfolio in flow shock

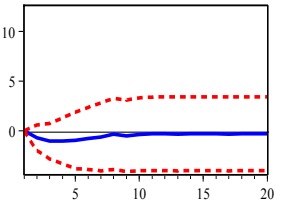

Response of portfolio in flow to portfolio in flow shock

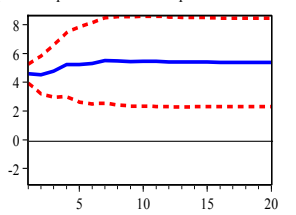

Response of bank credit inflow to portfolio inflow shock

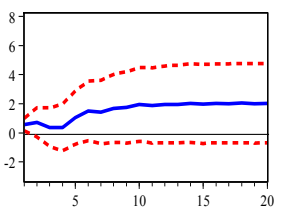

Response of UK GDP to bank credit inflow shock

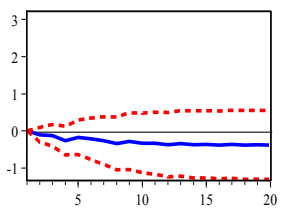

Response ofFDI in flow to bank credit in flow shock

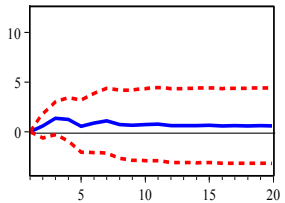

Response of portfolio inflow to bank credit in flow shock

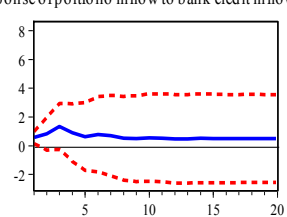

Response ofb ank credit inflow to bank credit inflow shock

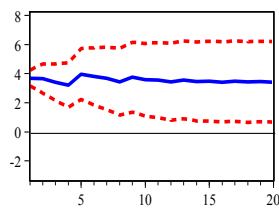


Figure 3-5-Impulse responses for equity inflow, debt inflow and UK GDP

Panel A: Sample period 1984 Q1 - 2016 Q1

Response ofUK GDP to UK GDP shock

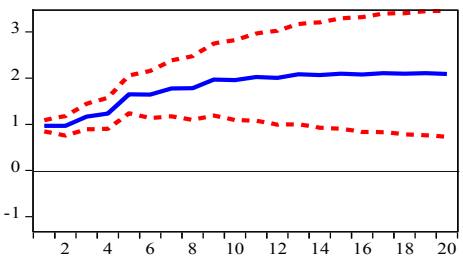

Response of equity inflow to UK GDP shock

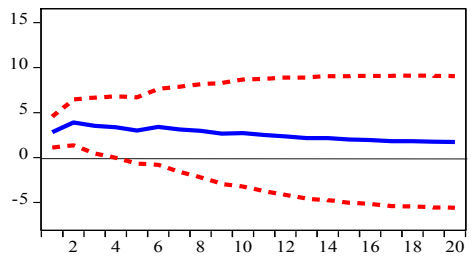

Response ofdebt inflow to UK GDP shock

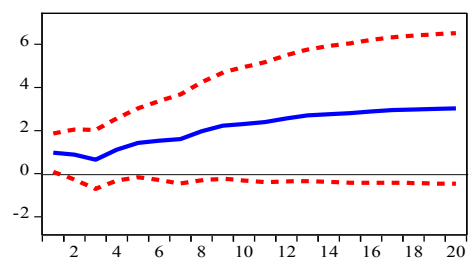

Accumulated Response to Structural VAR Innovations \pm 2 S.E.

Response of UK GDP to equity inflow shock

Response ofUK GDP to debt inflow shock

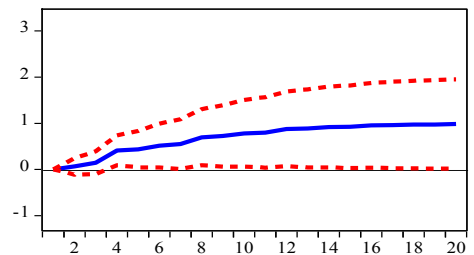

Response of equity inflow to equity inflow shock

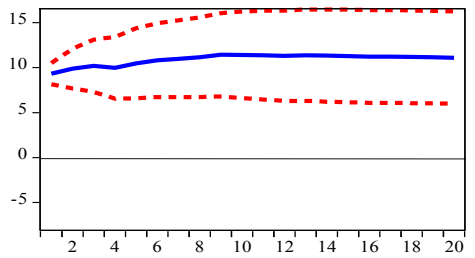

Response ofdebt inflow to equity inflow shock

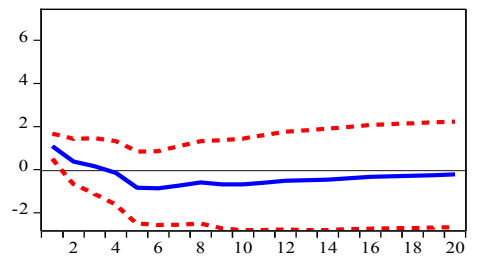

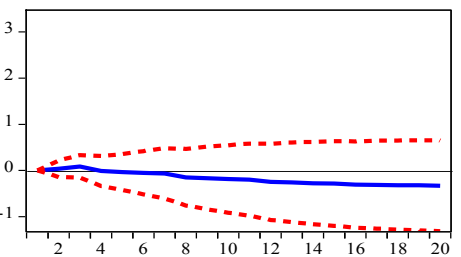

Response of equity inflow to debt inflow shock

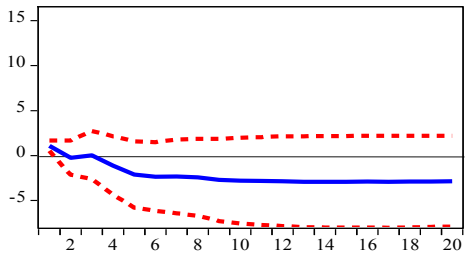

Response ofdebt inflow to debt inflow shock

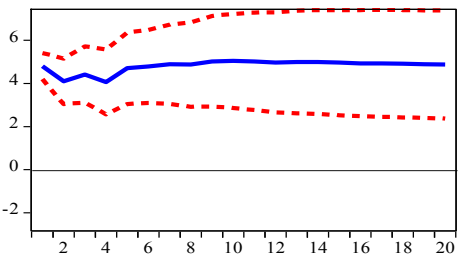




\section{Panel B: Sample period 1993 Q1 - 2016 Q1}

Accumulated Response to Structural VAR Innovations \pm 2 S.E.

Response of debt inflow to UK GDP shock

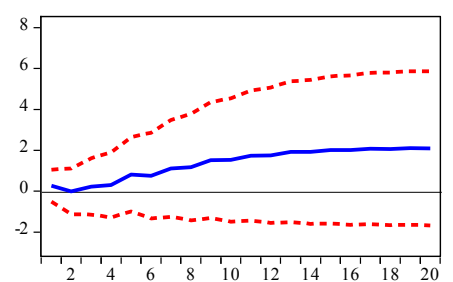

Response ofUK GDP to equity inflow shock

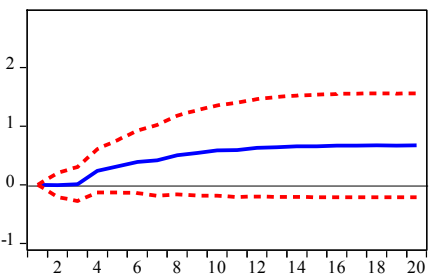

Response of equity inflow to equity inflow shock

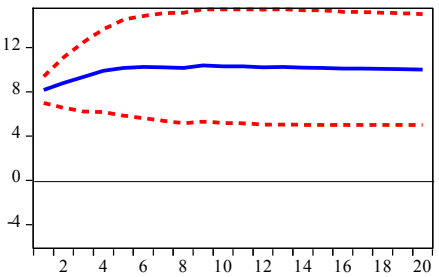

Response ofdebt inflow to equity inflow shock

Response ofUK GDP to debt inflow shock

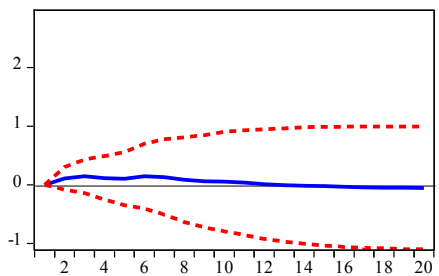

Response of equity inflow to debt inflow shock

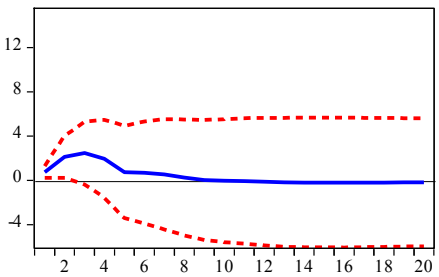

Response ofdebt inflow to debt inflow shock
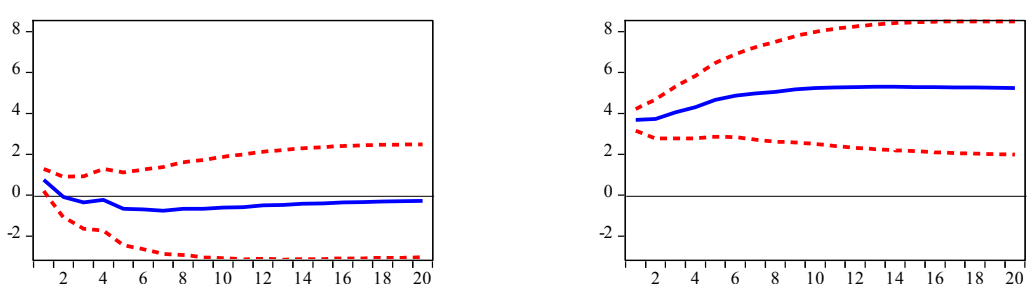


\section{Panel C: Sample period 1984 Q1 - 2007 Q4}

Response ofUK GDP to UK GDP shock

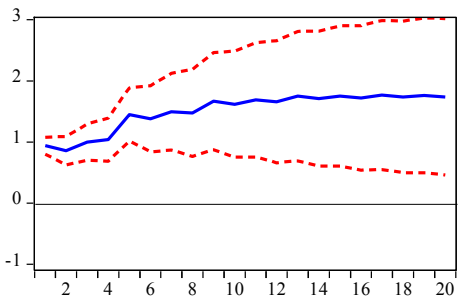

Response of equity inflow to UK GDP shock

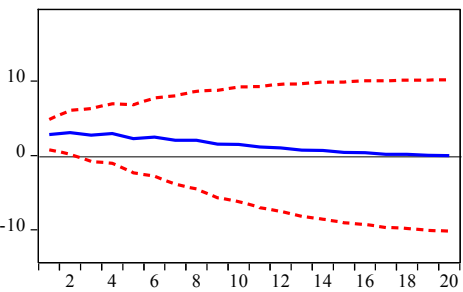

Response of debt inflow to UK GDP shock

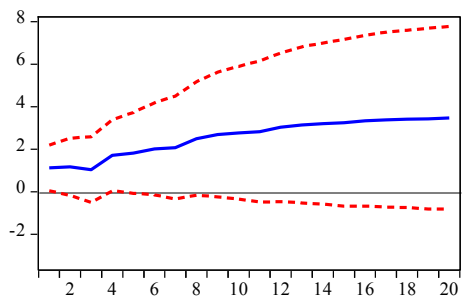

Accumulated Response to Structural VAR Innovations \pm 2 S.E.

Response ofUK GDP to equity inflow shock

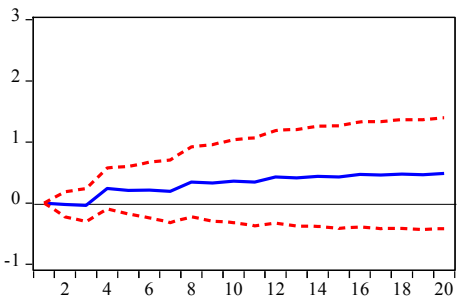

Response of equity inflow to equity inflow shock

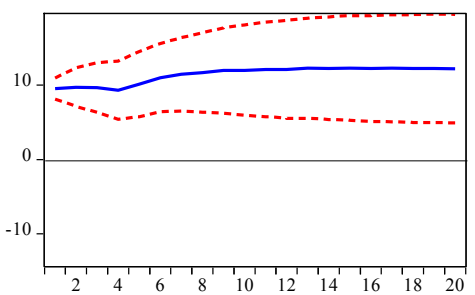

Response ofdebt inflow to equity inflow shock

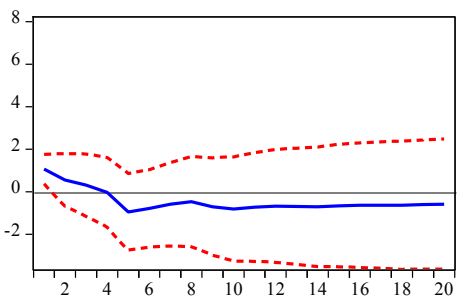

Response of UK GDP to debt inflow shock

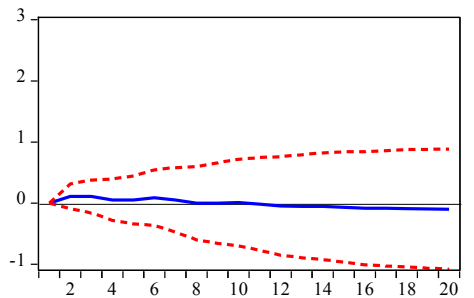

Response of equity inflow to debt inflow shock

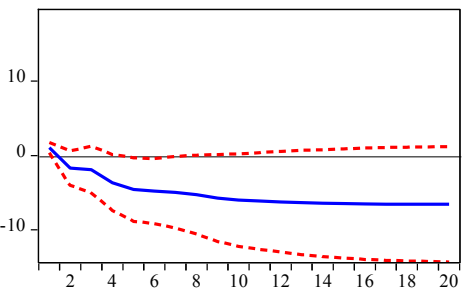

Response of debt inflow to debt inflow shock

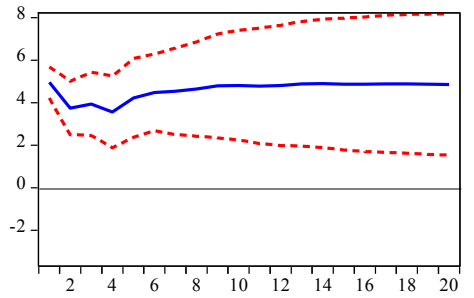


Figure 3-6-FAVAR impulse responses for equity inflow, debt inflow and UK GDP Accumulated Response to Structural One S.D. Innovations \pm 2 S.E.

Response of UK GDP to equity inflow shock

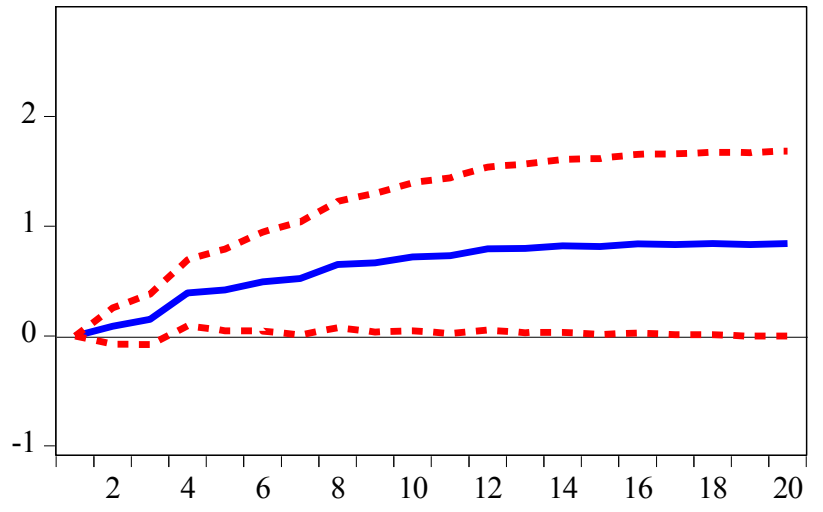

Response of UK GDP to debt inflow shock

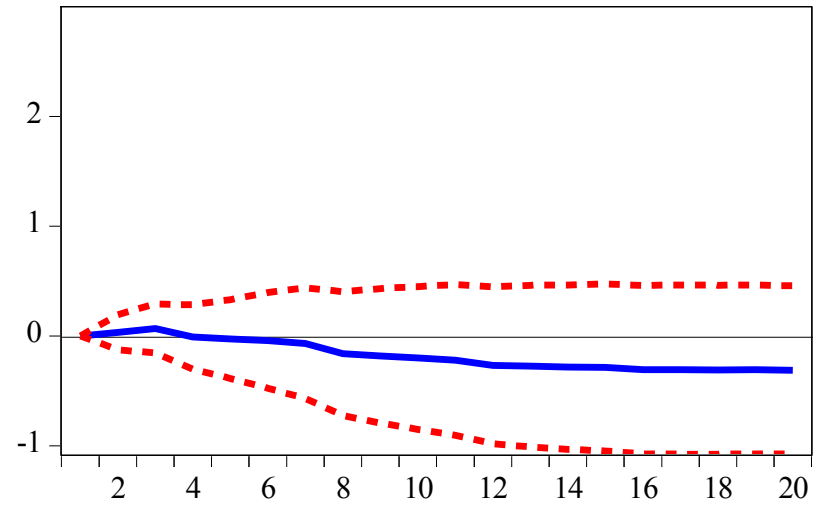


Figure 3-7-Impulse responses for equity inflow and debt inflow and UK investment

Panel A: Sample period 1984 Q1 - 2016 Q1

Response of UK investment to UK investment shock

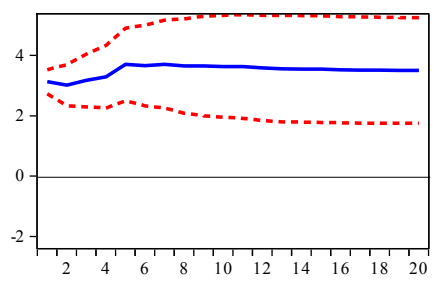

Response of equity inflow to UK investment shock

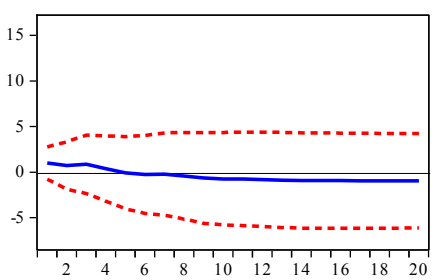

Response of debt inflow to UK investment shock

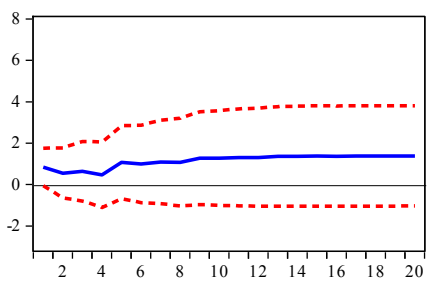

Accumulated Response to Structural VAR Innovations \pm 2 S.E.

Response of UK investment to equity inflow shock

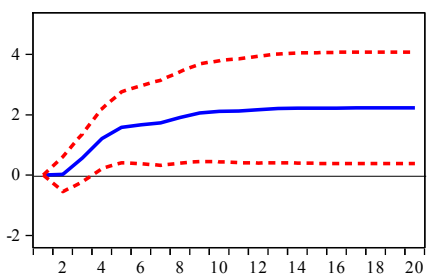

Response of equity inflow to equity inflow shock

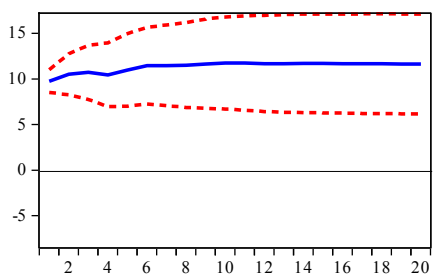

Response of debt inflow to equity inflow shock

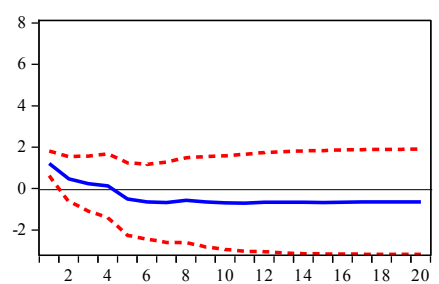

Response of UK investment to debt inflow shock

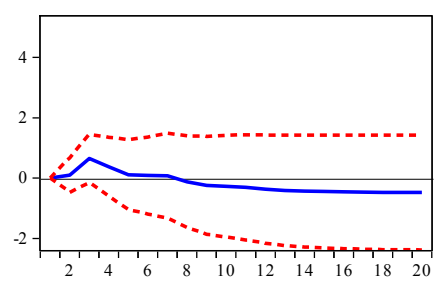

Response of equity inflow to debt inflow shock

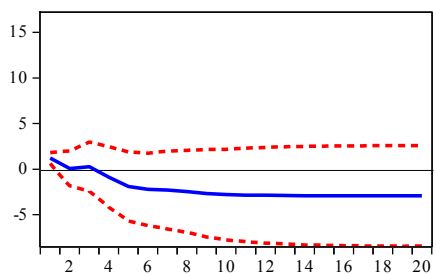

Response of debt inflow to debt inflow shock

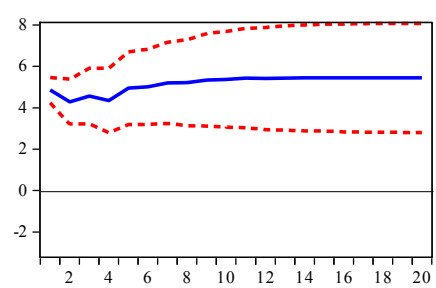




\section{Panel B: Sample period 1993 Q1 - 2016 Q1}

Accumulated Response to Structural VAR Innovations \pm 2 S.E.

Response of UK investment to UK investment shock

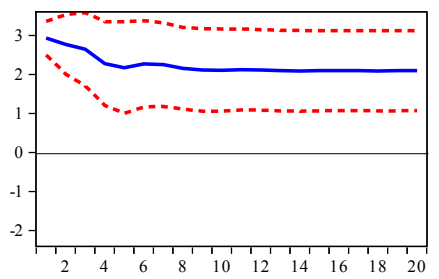

Response of equity inflow to UK investment shock

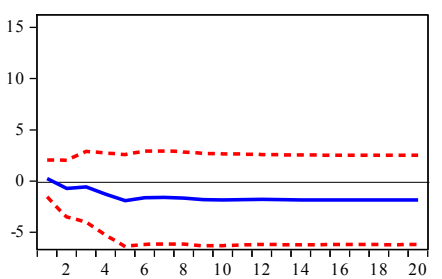

Response of debt inflow to UK investment shock

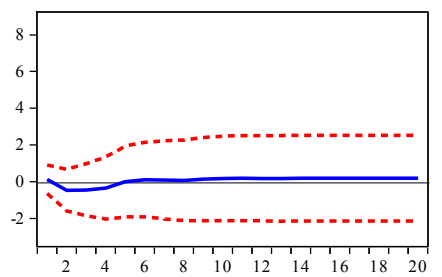

Response of UK investment to equity inflow shock

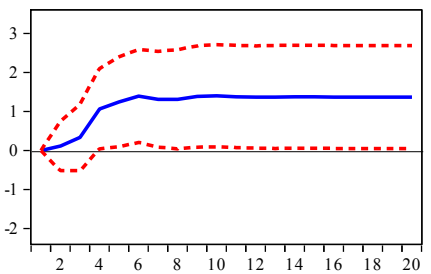

Response of equity inflow to equity inflow shock

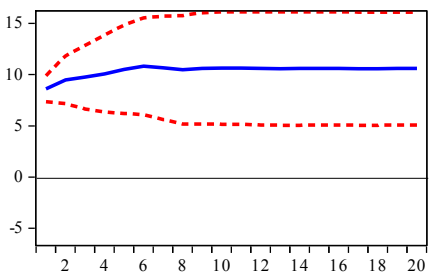

Response of debt inflow to equity inflow shock

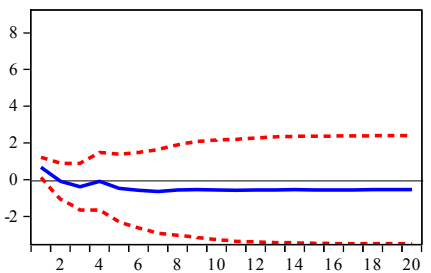

Response of UK investment to debt inflow shock

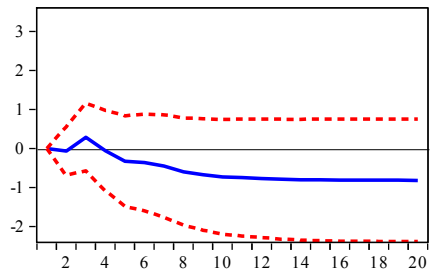

Response of equity inflow to debt inflow shock

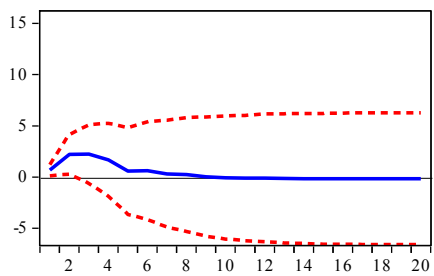

Response of debt inflow to debt inflow shock

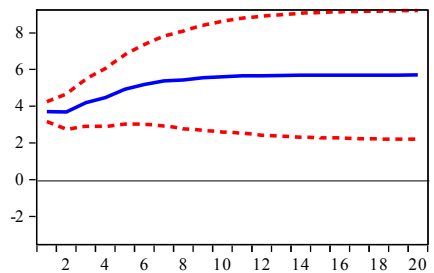




\section{Panel C: Sample period 1984 Q1 - 2008 Q1}

Accumulated Response to Structural VAR Innovations \pm 2 S.E.

Response of UK investment to UK investment shock

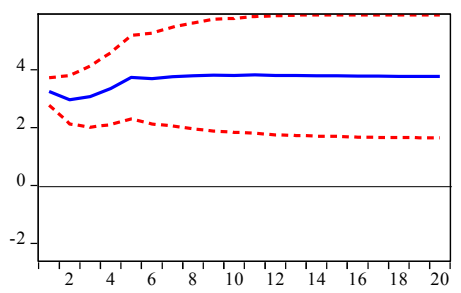

Response of equity inflow to UK investment shock

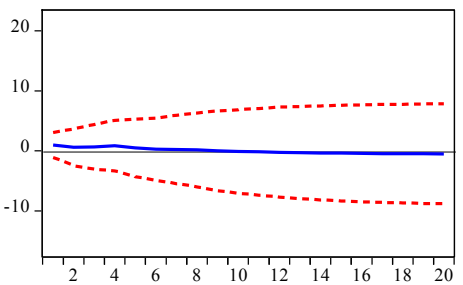

Response ofdebt inflow to UK investment shock

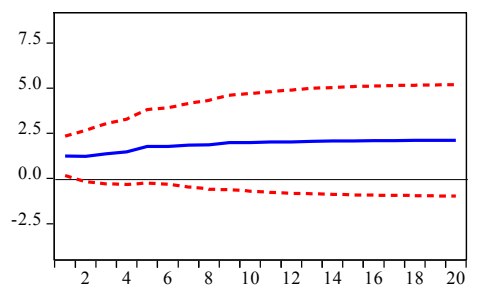

Response ofUK investment to equity inflow shock

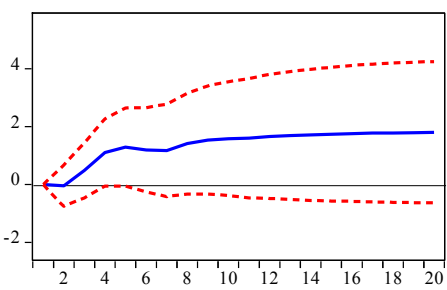

Response of equity inflow to equity inflow shock

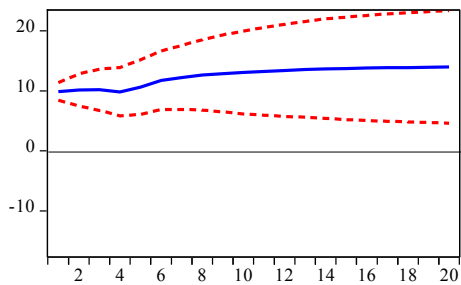

Response ofdebt inflow to equity inflow shock

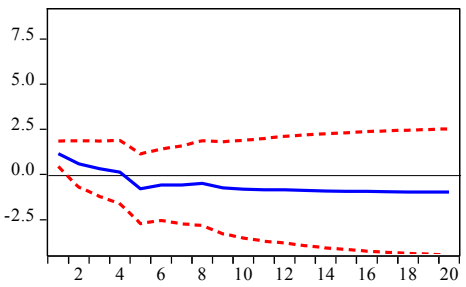

Response ofUK investment to debt inflow shock

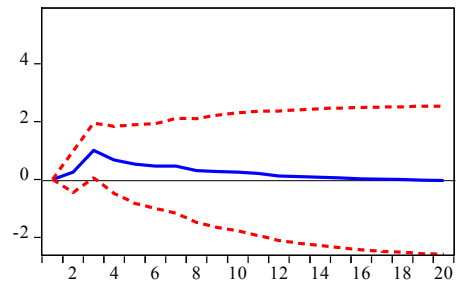

Response of equity inflow to debt inflow shock

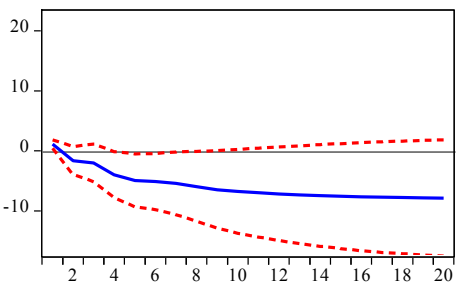

Response ofdebt inflow to debt inflow shock

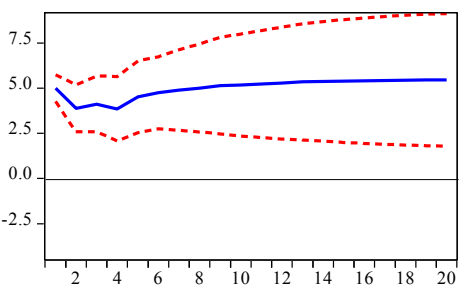


Figure 3-8-Impulse responses for equity inflow and debt inflow and UK consumption Panel A: Sample period 1984 Q1 - 2016 Q1

Accumulated Response to Structural VAR Innovations \pm 2 S.E.

Response ofUK consumption to UK consumption shock

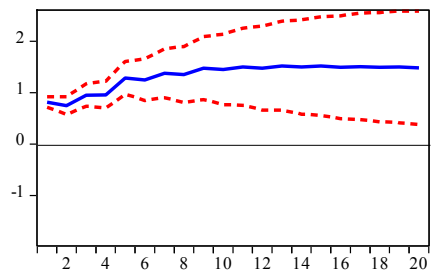

Response of equity inflow to UK consumption shock

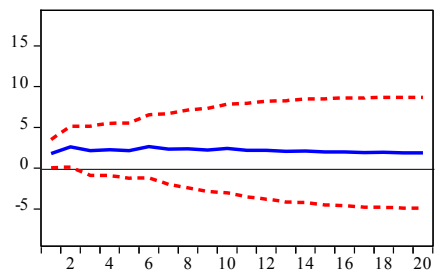

Response ofdebt inflow to UK consumption shock

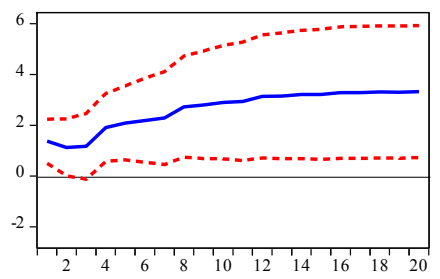

Response ofUK consumption to equity inflow shock

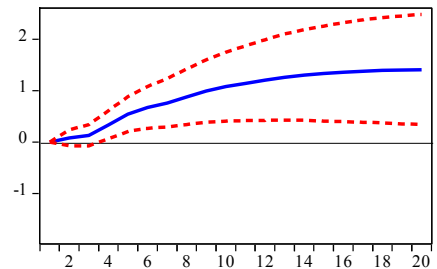

Response of equity inflow to equity inflow shock

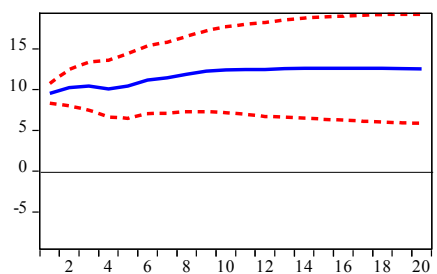

Response ofdebt inflow to equity inflow shock

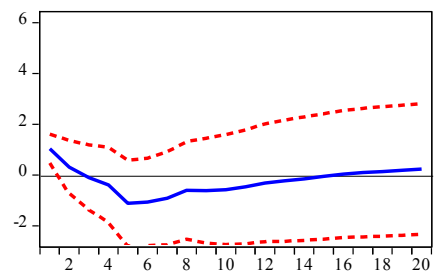

Response ofUK consumption to debt inflow shock

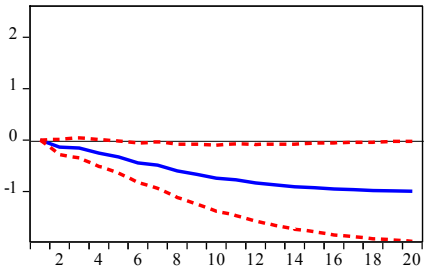

Response ofequity inflow to debt inflow shock

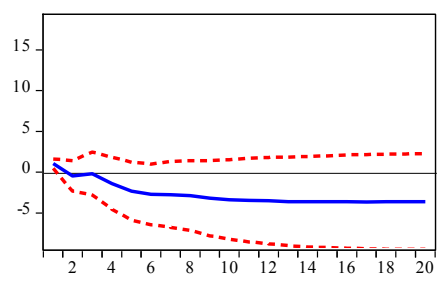

Response ofdebt inflow to debt inflow shock

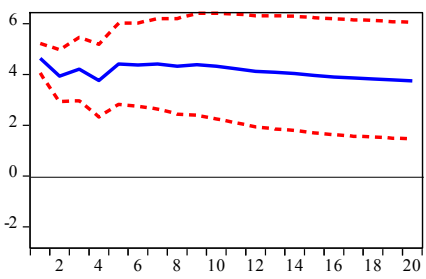




\section{Panel B: Sample period 1993 Q1 - 2016 Q1}

Accumulated Response to Structural VAR Innovations \pm 2 S.E.

Response ofUK consumption to UK consumption shock

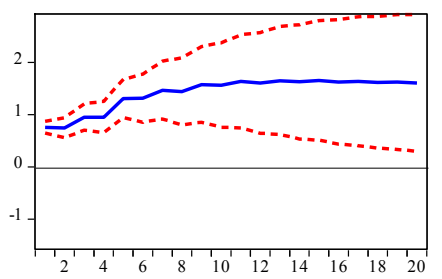

Response of equity inflow to UK consumption shock

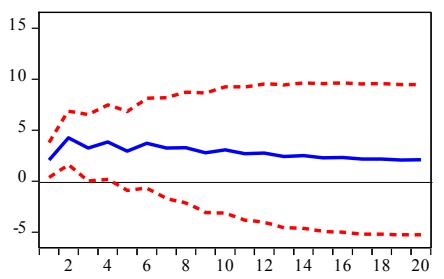

Response ofdebt inflow to UK consumption shock

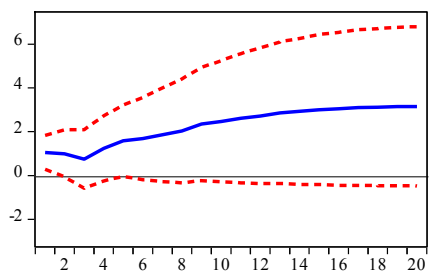

Response ofUK consumption to equity inflow shock

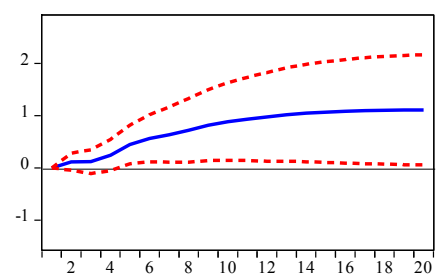

Response ofequity inflow to equity inflow shock

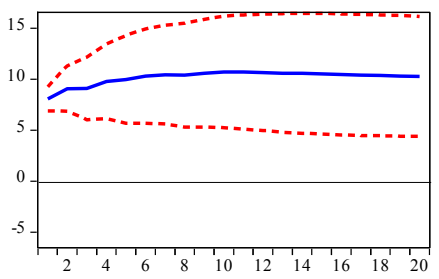

Response ofdebt inflow to equity inflow shock

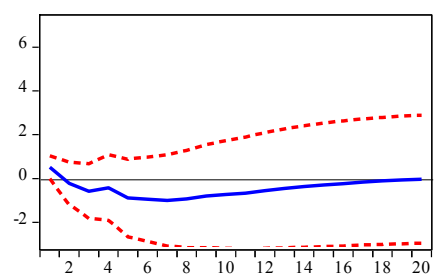

Response ofUK consumption to debt inflow shock

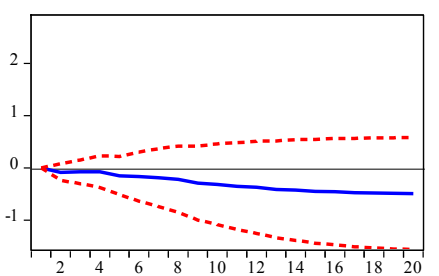

Response ofequity inflow to debt inflow shock

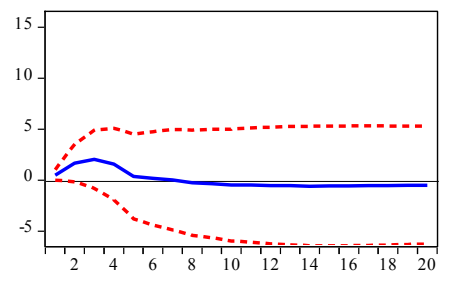

Response ofdebt inflow to debt inflow shock

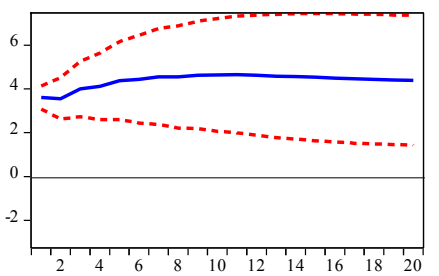




\section{Panel C: Sample period 2009 Q1 - 2016 Q1}

Accumulated Response to Structural VAR Innovations \pm 2 S.E.

Response ofUK consumption to UK consumption shock

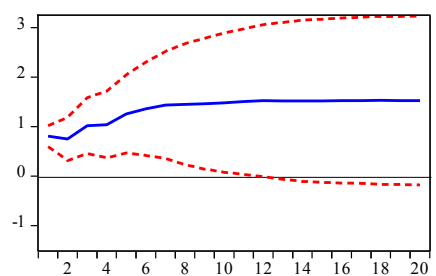

Response of equity inflow to UK consumption shock

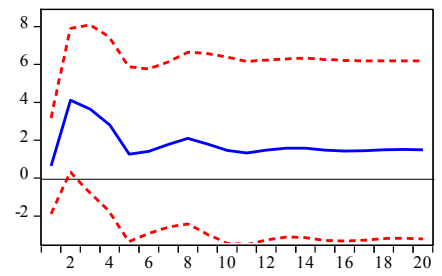

Response ofdebt inflow to UK consumption shock

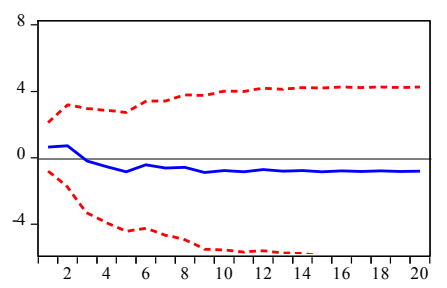

Response ofUK consumption to equity inflow shock

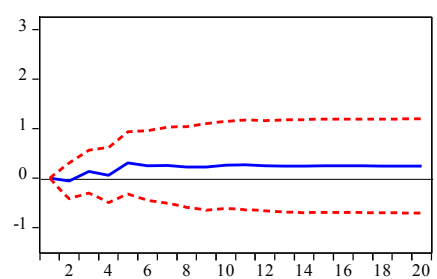

Response of equity inflow to equity inflow shock

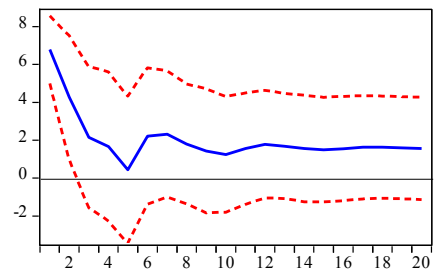

Response ofdebt inflow to equity inflow shock

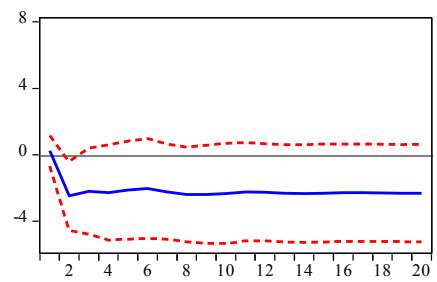

Response ofUK consumption to debt inflow shock

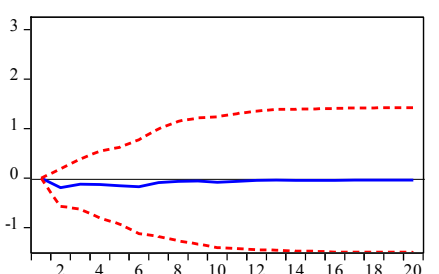

Response ofequity inflow to debt inflow shock

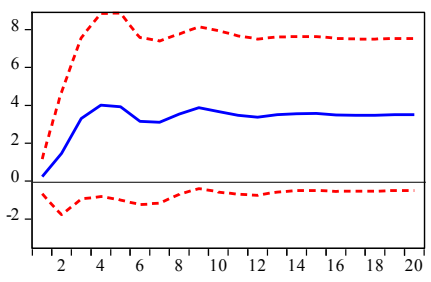

Response ofdebt inflow to debt inflow shock

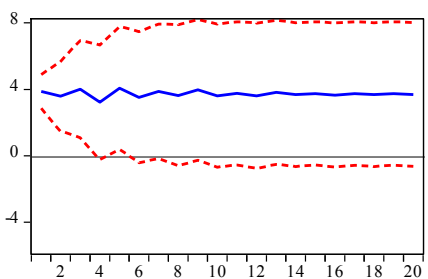




\section{Appendix 1: Capital inflow categories}

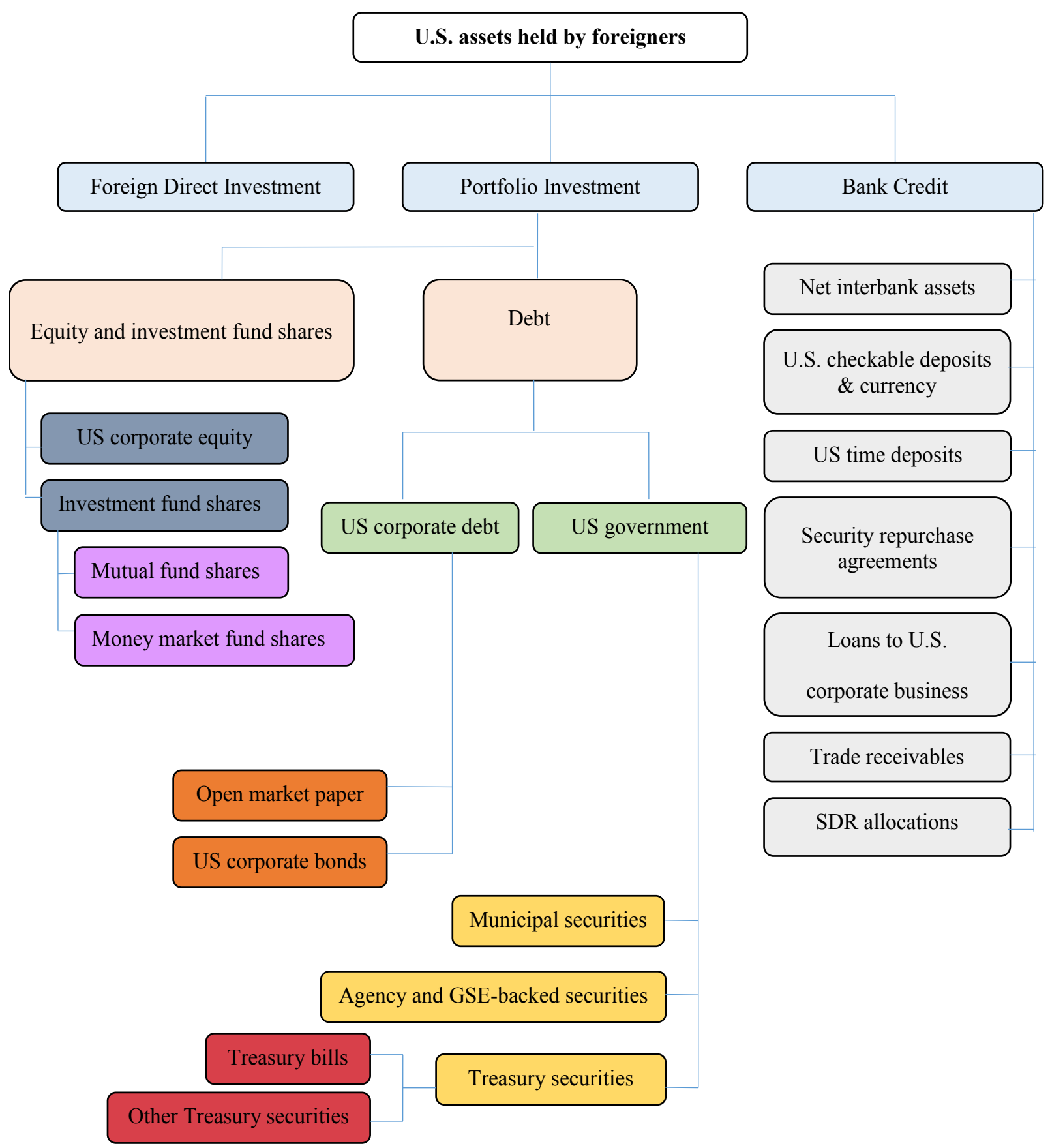




\section{Appendix 2}

P-values of unit root tests performed on logarithm of real variables

\begin{tabular}{|l|c|c|}
\hline Variables & ADF & Phillips-Perron \\
\hline Log of real GDP & 0.82 & 0.85 \\
\hline Log of real net capital inflow & 0.20 & 0.22 \\
\hline Log of real capital inflow & 0.74 & 0.75 \\
\hline Log of real capital outflow & 0.96 & 0.95 \\
\hline Log of real FDI inflow & 0.41 & 0.12 \\
\hline Log of real portfolio inflow & 0.72 & 0.76 \\
\hline Log of real bank credit inflow & 0.89 & 0.89 \\
\hline Log of real portfolio equity inflow & 0.84 & 0.83 \\
\hline Log of real portfolio debt inflow & 0.62 & 0.69 \\
\hline Log of real US corporate debt inflow & 0.11 & 0.11 \\
\hline Log of real US government debt inflow & 0.92 & 0.92 \\
\hline
\end{tabular}

P-values of unit root tests performed on growth of variables

\begin{tabular}{|l|c|c|}
\hline Variables & ADF & Phillips-Perron \\
\hline Real GDP growth & 0.00 & 0.00 \\
\hline Real net capital inflow growth & 0.00 & 0.00 \\
\hline Real capital inflow growth & 0.00 & 0.00 \\
\hline Real capital outflow growth & 0.00 & 0.00 \\
\hline Real FDI inflow growth & 0.01 & 0.00 \\
\hline Real portfolio inflow growth & 0.00 & 0.00 \\
\hline Real bank credit inflow growth & 0.00 & 0.00 \\
\hline Real portfolio equity inflow growth & 0.00 & 0.00 \\
\hline Real portfolio debt inflow growth & 0.00 & 0.00 \\
\hline Log of real US corporate debt inflow & 0.00 & 0.00 \\
\hline Log of real US government debt inflow & 0.00 & 0.00 \\
\hline
\end{tabular}




\section{Appendix 3: Capital outflow categories}

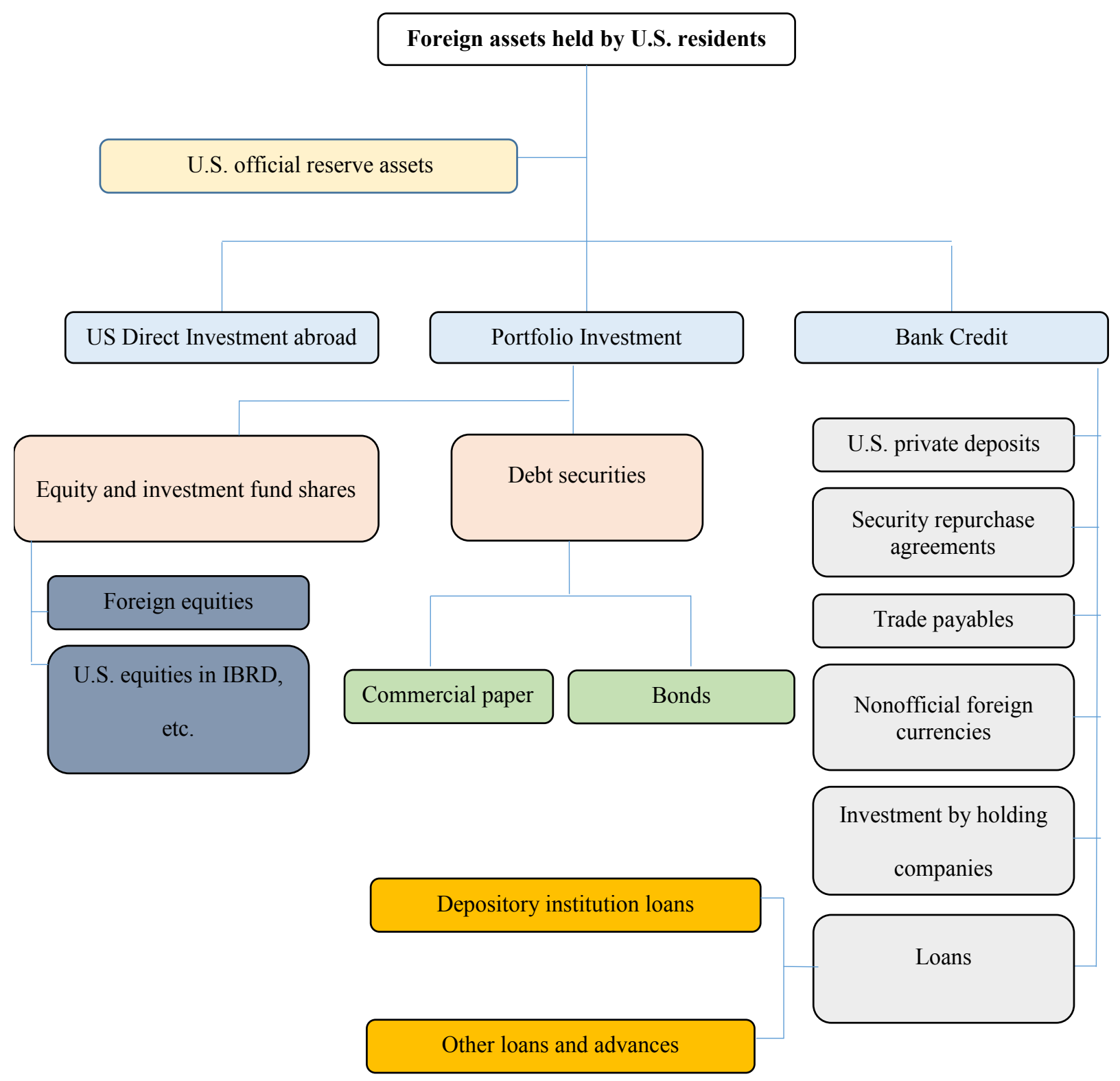




Appendix 4
P-values of unit root tests performed on logarithm of real variables
\begin{tabular}{|l|c|c|}
\hline Variables & ADF & Phillips-Perron \\
\hline Log of real GDP & 0.46 & 0.28 \\
\hline Log of real investment & 0.19 & 0.18 \\
\hline Log of real consumption & 0.39 & 0.12 \\
\hline Log of real net capital inflow & 0.16 & 0.09 \\
\hline Log of real capital inflow & 0.59 & 0.58 \\
\hline Log of real capital outflow & 0.74 & 0.74 \\
\hline Log of real FDI inflow & 0.72 & 0.72 \\
\hline Log of real portfolio inflow & 0.62 & 0.60 \\
\hline Log of real bank credit inflow & 0.57 & 0.55 \\
\hline Log of real portfolio equity inflow & 0.03 & 0.03 \\
\hline Log of real portfolio debt inflow & 0.91 & 0.92 \\
\hline
\end{tabular}

P-values of unit root tests performed on growth of variables

\begin{tabular}{|l|c|c|}
\hline Variables & ADF & Phillips-Perron \\
\hline Real GDP growth & 0.03 & 0.00 \\
\hline Real investment growth & 0.00 & 0.00 \\
\hline Real consumption growth & 0.08 & 0.00 \\
\hline Real net capital inflow growth & 0.00 & 0.00 \\
\hline Real capital inflow growth & 0.00 & 0.00 \\
\hline Real capital outflow growth & 0.00 & 0.00 \\
\hline Real FDI inflow growth & 0.00 & 0.00 \\
\hline Real portfolio inflow growth & 0.00 & 0.00 \\
\hline Real bank credit inflow growth & 0.00 & 0.00 \\
\hline Real portfolio equity inflow growth & 0.00 & 0.00 \\
\hline Real portfolio debt inflow growth & 0.00 & 0.00 \\
\hline
\end{tabular}

